\title{
Revision of the Lerista muelleri species-group (Lacertilia: Scincidae) in Western Australia, with a redescription of $L$. muelleri (Fischer, 1881) and the description of nine new species
}

\author{
L.A. Smith ${ }^{1}$ and M. Adams ${ }^{2}$ \\ 'clo Department of Terrestrial Vertebrates, Western Australian Museum, 49 Kew Street, \\ Welshpool WA 6106, e-mail - smithloechidna.id.au \\ 2Evolutionary Biology Unit, South Australian Museum, South Terrace, Adelaide SA 5000
}

\begin{abstract}
The Australian scincid genus Lerista comprises more than 80 species of small semifossorial and fossorial lizards. Most species are found in arid and semiarid regions. These species are divided into species groups which are largely diagnosed by their digital formulae. Most L. muelleri species group members have a digital formula of three fingers and three toes, some four fingers and four toes. Only one species has two fingers and three toes. Hitherto $L$. muelleri has been considered a single pancontinental species which, together with $L$. allochira and $L$. haroldi, comprised the relatively small L. muelleri species group within the speciose genus Lerista. A detailed examination of morphological and genetic variation in Western Australian specimens has indicated that species-level diversity within the $L$. muelleri species group has been greatly underestimated. Here, 13 species are recognised: the previously described $L$. allochira (Kendrick 1989), L. haroldi (Storr 1983), L. muelleri (Fischer 1881) and L. rhodonoides (Lucas and Frost 1896; resurrected from the synonymy of $L$. muelleri) plus nine new species: $L$. amicorum sp. nov., L. clara sp. nov., L. jacksoni sp. nov., L. kingi sp. nov., $L$. micra sp. nov., L. nevinae sp. nov., $L$. occulta sp. nov., $L$. rolfei sp. nov. and $L$. verhmens sp. nov. Lerista goerlingi (Ahl 1935) is retained in the synonymy of $L$. rhodonoides. Support for the validity of eleven of the thirteen species is demonstrated using allozyme analysis of 114 specimens at 46 loci. Lerista muelleri (sensu stricto) is shown to be restricted to the Pilbara plateau and its rocky outliers in northwest Western Australia. One of the two syntypes of $L$. muelleri that were considered lost has recently been rediscovered and is nominated as lectotype.
\end{abstract}

Key words: Lacertilia, Lerista, Pilbara, Scincidae, systematics

\section{INTRODUCTION}

Members of the huge Australian lizard genus Lerista are small semi-fossorial and fossorial skinks with varying degrees of limb reduction. Most species are found in the arid and semiarid regions of Western Australia. Unlike many species of lizard where reasonable numbers can be accumulated by opportunistic collecting, acquisition of a suitable numbers of Lerista requires many hours of raking and digging in conjunction with pit-trapping. It is not surprising then, that truly representative collections of these elusive lizards did not begin to be made until the 1970s when intensive systematic collecting of habitats through biological surveys became an essential part of assessing faunal diversity. The first Lerista was described 173 years ago ( $L$. lineata Bell 1833) but most have been described in the last 30 years.

Glen Storr, former Curator of Reptiles at the Western Australian Museum, spent a large part of his 28 years in the job unraveling the systematic complexities of the genus Lerista. When he began his curatorship there were only 16 species of Lerista known from Western Australia (then placed in Rhodona or Ablepharus depending on whether the eyelid was movable or a fixed spectacle). That number has increased to more than 50 and all but a few of the additional species have been described by Storr.

Over the last 30 years the various species-groups of Lerista identified (Storr 1972; Storr et al. 1981, 1999; Greer et al. 1983; Greer 1986; Kendrick 1991) have been under almost constant scrutiny and revision. As an example, for many years $L$. nichollsi (Loveridge 1933) was only known from a few specimens. A steady flow of new material over the last two decades prompted three revisions (Storr $1984,1986,1991$ a) which together established $L$. nichollsi as a species group distributed along the mid west coast of Western Australia and its hinterland. Similarly, a number of other species described in the 1800s and early 1900s proved to be 
the first described member of a species group. Most of these species groups, like the L. nichollsi group, have geographically restricted distributions. Another example is the $L$. bipes group which is largely confined to the northwest of the continent (Storr et al. 1999).

Greer (1979) placed Lerista in the subgroup Sphenomorphus within the Lygosominae. Greer and Shea (2003) used secondary temporal scale overlap patterns to futher refine sphenomorphine skink systematics. The genus is currently considered to comprise eight species groups (Aplin and Smith 2001). Of these, the semi-fossorial $L$. muelleri group, which ranges widely across southern Australia (Figure 1), has attracted the least attention.

Glauert (1961) recognised two forms of threefingered, three-toed Ablepharus in Western Australia, namely Ablepharus [Lerista] rhodonoides, a species "widespread in the interior of the state" with fused frontoparietals, and $A$. muelleri from the upper west coast and Pilbara region, which has the second supraciliary fused with the first supraocular and the frontoparietals free. Lygosoma (Rhodona) goerlingi Ahl 1935 , which also has fused frontoparietals, was treated as a synonym of $A$. rhodonoides.

When Storr (1971) first revised Lerista he remarked on a number of regionally distinct populations of L. muelleri but his conclusions were unusually conservative, even more so than Glauert, for he used $L$. muelleri for all three-fingered, threetoed Lerista, regardless of their frontoparietal and supraciliary condition.

Although the L. muelleri group has had little attention, it has not been totally neglected. Urged on by G. Harold, the doyen of Lerista-hunters, Storr re-examined the Western Australian Museum's Lerista collection in the early $1980^{\prime}$ s. This resulted in the description of L. haroldi (Storr 1983). Six years later Kendrick (1989) described L. allochira, unique in the group in having only two fingers and only one presubocular (two in all other forms).

Shea (1991) re-examined the holotype of Lygosoma (Rhodona) goerlingi (Ahl 1935). He agreed with the tentative actions of Storr (1971) and Cogger et al. (1983) in synonymising L. goerlingi with L. muelleri. Two other names proposed for

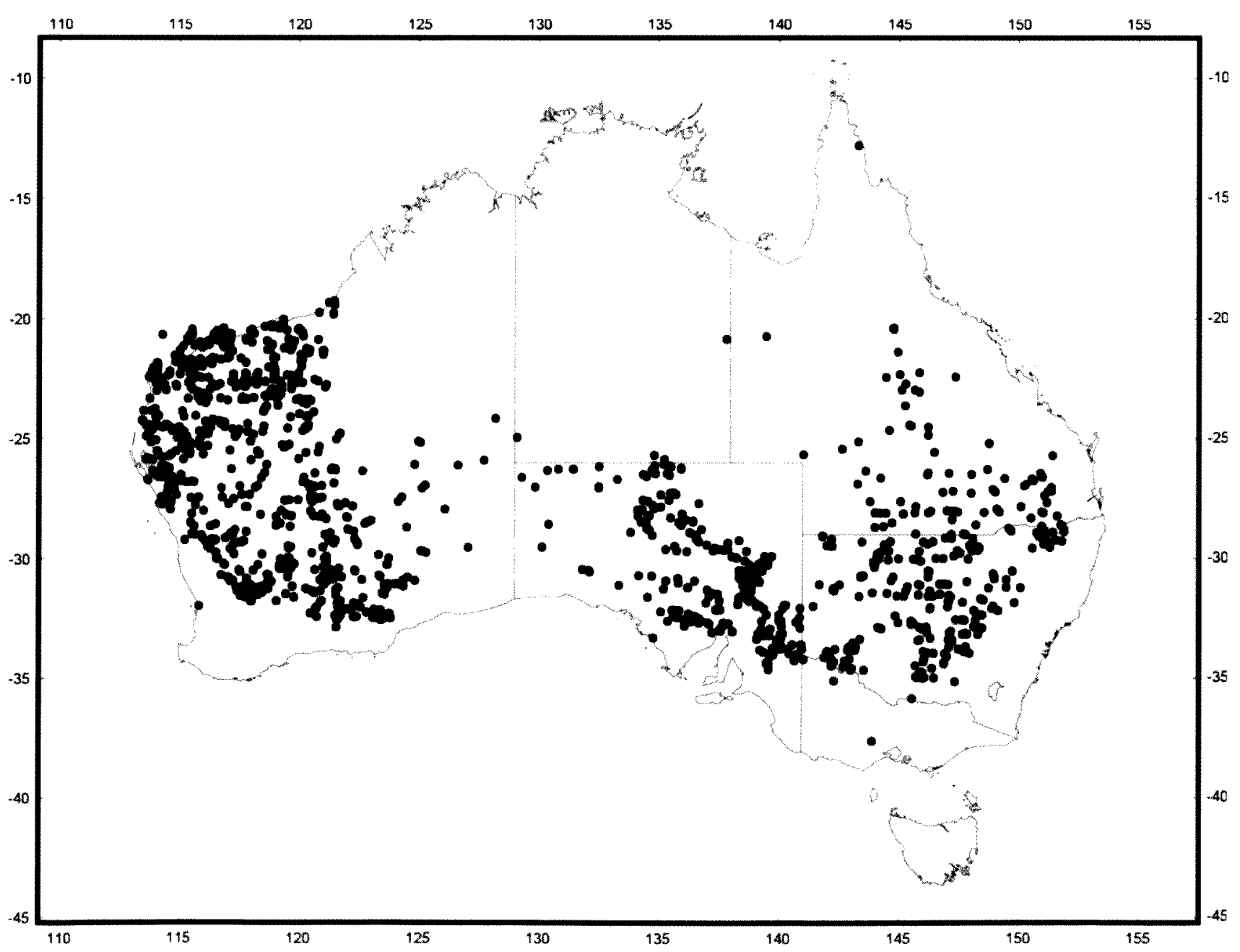

Figure 1 Distribution of Lerista muelleri across Australia as currently recognised. Data from Australian museum collections. 
different forms of three-fingered, three-toed Lerista, have been placed in the synonymy of muelleri (Cogger et al. 1983): L. timidus De Vis 1888 (type locality Charleville, Queensland) and $L$. rhodonoides (Lucas and Frost 1896)(type locality Mildura, Victoria).

When Storr described L, haroldi (Storr 1983) he suspected other species apart from $L$. haroldi were embedded in the L. muelleri complex but lacked the morphological criteria to diagnose them. Indeed, it was only its almost total lack of dorsal pattern that convinced him of the validity of $L$. haroldi.

K. Aplin, M. Adams and M. Cowan (unpublished data) used morphology and allozyme electrophoresis to identify four forms of L. muelleri in the Carnarvon Basin. Aplin followed this work with a pilot study of $L$. muelleri morphology with the help of voluntary worker C. Taylor. After Taylor, L. A. Smith expanded the pilot study, largely to try to understand the increasing complexities of the group being exposed by the rapidly growing collection, now in the order of 2000 specimens. By 2001 all available specimens had been examined. Thirteen morphotypes (including described species) had been identified and their distributions mapped. Genetic analysis of most of the morphotypes was made possible through an environmental impact assessment on the Burrup peninsula for a development where two of the morphotypes were known to be sympatric.

\section{MATERIALS AND METHODS}

A major strength of this study and that of Aplin and colleagues is the use of allozyme electrophoresis to examine the validity of the taxa identified via morphology. Frozen tissues were available for all but two of the 13 morphospecies, with one of the two species without tissue samples being the most distinctive morphologically (the previously described L. allochira, the only twofingered member of the group), and the other ( $L$. amicorum) a geographically restricted species similar to the widespread L. rhodonoides.

This study is based on examination of nearly 2000 specimens, virtually all of them lodged in the Western Australian Museum. In the lists of paratypes and material examined WA Museum specimens are unprefixed. Acronyms for other institutions are: Australian Museum (AM), Museum Victoria (MV), South Australian Museum (SAM), Zoological Museum Berlin (ZMB).

The analysis presented here involves a large number of taxa, most of which are new species. Thus, for clarity all new binomials are introduced now and used throughout.

Number of specimens examined for each taxon are as follows: L. allochira (26), L. amicorum (21), L. clara (198), L. haroldi (6), L, jacksoni (46), L. kingi (259), L. micra (418), L. muelleri (89), L. nevinae (3), L. occulta (27), L. rhodonoides (460), L. rolfei (276) and $L$. verhmens (12). Specimens with asterisks are those used in the genetic analysis.

As thorough as this Western Australian revision is, the prospect remains that additional undescribed species exist in the group. Given that one of the new species ( $L$. occulta) was initially identified using genetic criteria and that less than $20 \%$ of the available tissue vouchers have been examined, it is possible there may be additional, geneticallydiagnosable species present. Moreover, there is some evidence of two additional taxa, one within $L$. clara and another within $L$. kingi, as currently recognised herein. Details of these specimens are dealt with separately in the descriptions of these species.

\section{Morphology}

The main reason Storr could not confirm his suspicions that $L$. muelleri comprised a number of species was because he did not employ enough characters or take into account the existence of sexual dimorphism. He did not count paravertebrals and he did not take detailed notes on colour pattern. Had he included these in the array of character states he always scored he would have noticed that certain colour patterns were concordant with certain frontoparietal and supraciliary configurations and paravertebral ranges. The precise position and nature of particular dorsal and lateral pattern elements is an essential consideration in identifying members of the $L$. muelleri species group. Some of the pattern differences between taxa are quite stark, and it is likely that detailed pattern descriptions would have been invoked long ago as an aid to distinguish taxa if the lizards in question were larger.

The 13 morphotypes identified in the present study considers all of these conditions, together with a detailed assessment of other variable characters. Appendix 1 summarises data for 12 meristic and mensurable characters for males, females and a pooled sample of both sexes including unsexed individuals for each species. Degree of contact between the nasals, condition of the frontoparietals, number of supraoculars, presuboculars and midbody scale rows was also scored.

\section{Locating pattern elements on particular scale rows}

All pattern elements are described in relation to the paravertebral series. The paravertebral scale row on each side of the midline is row one; the adjacent lateral row is row two; the next adjacent lateral row is row three and so on, up to row 10 (all but three species in the $L$. muelleri species group usually have 20 midbody scales). The third row of scales 
from the midline is important because it contains the dorsolateral stripe. The medial third (or thereabouts) of scale row three marks the lateral extremity of the back and, like dorsal rows one and two is usually olive, brown or grey. The central third contains the pale dorsolateral stripe (never strong, usually discernable, sometimes absent). The lateral third (or thereabouts) marks the upper (medial) limit of the upper lateral stripe. Pattern elements on scale rows one to three (the presence, absence or relative strengths of dots and dashes) were also scored to assess their importance as an aid to identification.

The details of back pattern (the area between the upper edges of the upper lateral stripe) do not by themselves identify taxa. Although less simple and (unfortunately) less easily described, the lateral pattern is much more helpful in identifying species in the group.

Depending on the species, the upper lateral stripe has several degrees of prominence. It is most obvious in L. clara where it is almost always solid blackish-brown and covers 1.5 scales (lateral part of row three, all of row four and medial part of row five). In most species the upper lateral stripe is found on the lateral part of row three and all or part of row four and is never solid blackish brown, but parti-coloured, with the anterior portion on each scale blackish-brown and the posterior portion pale or with its lower margin heavily scalloped. In some cases the upper lateral stripe is reduced to a line of dots.

Dorsal scale rows five to eight contain pattern details which, while not absolutely diagnostic, are important in helping to identify specimens. These details include the presence, absence and configuration of the pigment on those particular rows.

Some of the characters that do not contribute to a diagnosis are not presented in the species' accounts. One case is with the two loreal scales. However, there is a good deal of variation in the two loreal shields ranging from subequal to unequal in size. If not subequal, the anterior is always the larger, sometimes very much larger than the posterior. Other characters are: number of upper labials (six, fourth under eye), postsuboculars (two), primary temporals (one), secondary temporals two, (upper much the larger and overlapped by the lower), eye ablepharine, ear aperture very small, infralabials six (first two contacting postmental) and three pairs of enlarged chin shields (second pair separated by a median shield).

\section{Supraciliaries}

There are three basic supraciliary conditions (see Figure 2):

- five, with the second and last smallest and third and fourth largest (Figure 2a),

- four (first and second fused)(Figure 2b) and

- three (second fused to first supraocular) (Figure 2c).

Taxa that normally have five supraciliaries are sometimes reduced to four when the first and second fuse or when the very small fifth fuses to the fourth. Taxa that normally have four supraciliaries are sometimes reduced to three when the very small fourth fuses with the third.
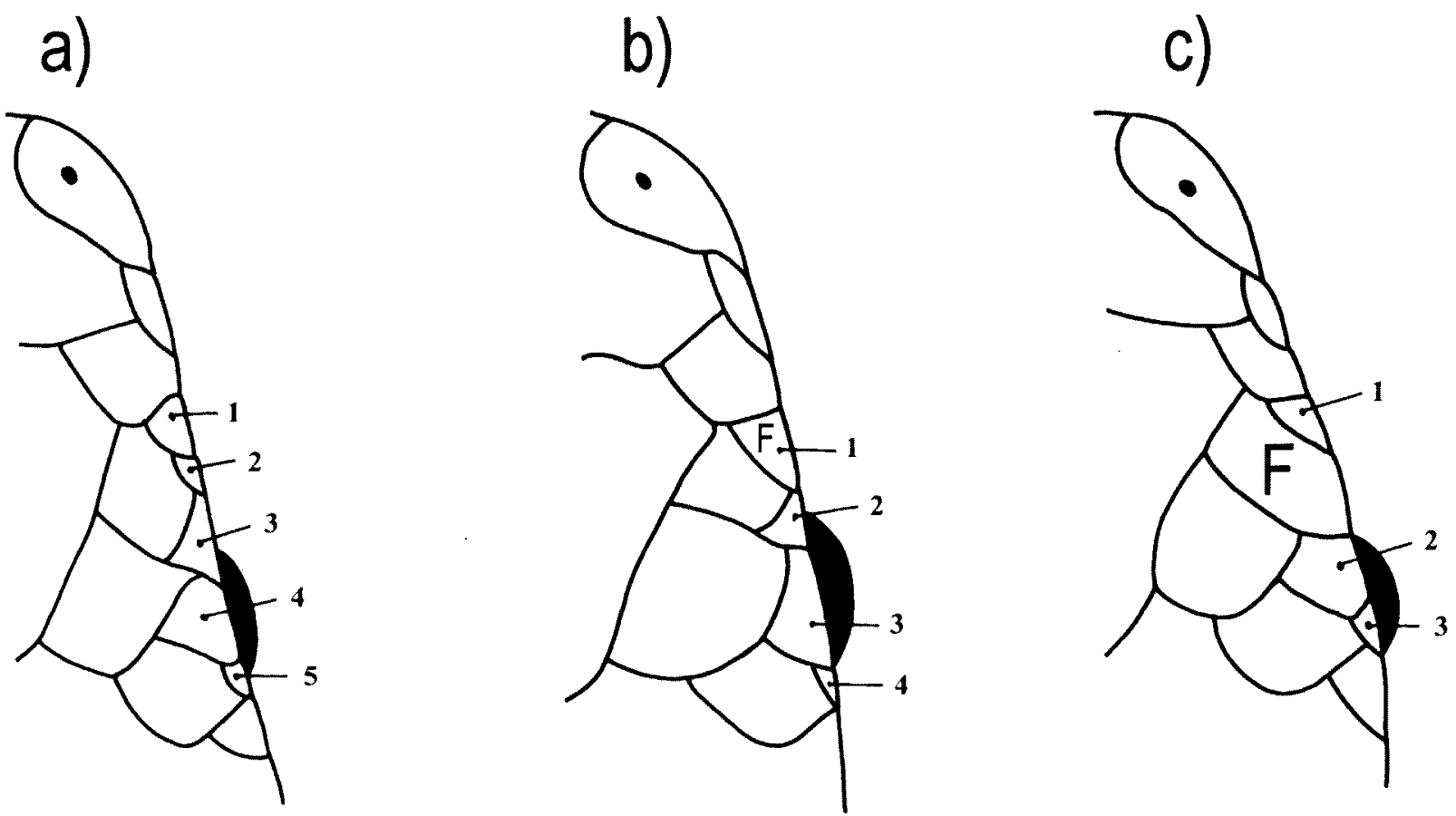

Figure 2 Supraciliary arrangements in the Lerista muelleri species group: (a) five supraciliaries; (b) four supraciliaries (first and second fused); (c) $1+2$ supraciliaries (first supraocular fused with second supraciliary). 


\section{Frontoparietals and interparietal}

There are two possible conditions with the frontoparietals. A pair of scales in contact or a single chevron-shaped scale created by the fusion of the paired scales. The interparietal is always free.

\section{Paravertebrals}

Paravertebrals range from the high $50 \mathrm{~s}$ in some taxa to as high as the low 90s in others. Mean number of paravertebrals in females always number more than in males (Appendix 1.12). Paravertebrals were counted from the first pair directly behind the parietals to a point directly above the vent on the rump.

\section{Presuboculars}

Two, except in L. allochira where there is one (Kendrick 1989, Figure 1a). In species with two, the anterior scale is nearly always much larger than the posterior scale which is not only very small but usually long and narrow (see Shea 1991, Figure 1). Here we follow Shea (1991) in nominating the two scales immediately behind the second loreal, above the third upper labial and before the subocular as the presubocular. In $L$, allochira the single presubocular is in a notch between the third and fourth upper labial. Apart from diagnosing $L$. allochira, this character is not diagnostic of the other species.

\section{Nasals}

Although the degree of nasal contact is always used in skink descriptions and often used to support diagnoses of Lerista species, it is generally scored qualitatively (e.g., $L$. elegans versus $L$. distinguenda in the $L$. elegans species group). In this study the nature of contact is quantified by assigning (by estimation not measurement) one of five degrees of contact: nasals separated $=1$, nasals in point contact (no discernable common suture) $=$ 2 , nasals in short contact $=3$, nasals in moderately long contact $=4$, nasals in long contact $=5$. A mean score (index) is given for each species.

\section{Nuchals}

All nuchals were counted. For example, three on the left plus two on the right totals five.

\section{Subdigital lamellae}

The number of subdigital lamellae on the shortest and longest toe and middle finger (except $L$. allochira) were scored. The claw was not counted.

\section{Limb proportions}

Foreleg (FL), hindleg (HL) and tail (TL) length are expressed as a percentage of snout-vent length (SVL). Foreleg and hindleg length were measured to the nearest $0.5 \mathrm{~mm}$ with the limb flattened on a ruler abutting the trunk and excluded the claw. Only original tails were measured. Tails were considered original when dorsal pattern elements, particularly the continuation of the dark upper lateral stripe, continued to tail tip. Data for SVL, limb lengths, limbs as a ratio of SVL, TL and tail as a percentage of SVL are presented in Appendix 1.

\section{Genetics}

\section{Animals examined}

Liver samples from about 850 L. muelleri group animals were available in the frozen tissue collections of the Western Australian and South Australian Museums. From these 114 tissues were selected (see Appendix 2 for specimen details) to cover the morphological and ecological variability encountered within the Western Australian members of the species group, based on the following criteria.

(a) All available coastal material (Anna Plains to Murchison River). The heavily dissected Pilbara coastal plain, with its rocky Pilbara plateau outliers (like Burrup peninsula) and variety of soil types (white coastal sand dunes, red sand dunes and loamy alluvial soils) often in close proximity, was considered to have the greatest potential to support localised endemic species. Selecting coastal samples south to the Murchison River linked forms identified herein to those identified by Aplin and colleagues (unpublished data).

(b) Inland records from the Pilbara south to the wheatbelt and east into the Great Victoria, Gibson and Little Sandy Deserts. In this case, tissues were preferentially selected from sites where the putative $L$. 'muelleri' species occur in sympatry or parapatry.

(c) A series of $L$. goerlingi/rhodonoides from South Australia and New South Wales were included to resolve the relationship between these two nominal species.

\section{Allozyme analyses}

Allozyme electrophoresis was undertaken on cellulose acetate gels ("Cellogel", M.A.L.T.A., Milan) according to the principles and procedures detailed in Richardson et al. (1986). The following enzymes or non-enzymatic proteins displayed sufficient activity and resolution to allow allozymic interpretation: aconitase hydratase (ACON, EC 4.2.1.3), acid phosphatase (ACP, EC 3.1.3.2), aminoacylase (ACYC, EC 3.5.1.14), alcohol dehydrogenase (ADH, EC 1.1.1.1), adenylate kinase (AK, EC 2.7.4.3), albumen (ALB), carbonate dehydratase (CA, EC 4.2.1.1), diaphorase (DIA, EC 1.6.99.), enolase (ENOL, EC 4.2.1.11), esterase (EST, EC 3.1.1.), fructose-bisphosphatase (FDP, EC 3.1.3.11), fumarate hydratase (FUM, EC 4.2.1.2), 
guanine deaminase (GDA, EC 3.5.4.3), lactoylglutathione lyase (GLO, EC 4.4.1.5), aspartate aminotransferase (GOT, EC 2.6.1.1), glucose-6phosphate dehydrogenase (G6PD, EC 1.1.1.49), glycerol-3-phosphate dehyrogenase (GPD, EC 1.1.1.8), glucose-6-phosphate isomerase (GPI, EC 5.3.1.9), glutathione reductase (GSR, EC 1.6.4.2), guanylate kinase (GUK, EC 2.7.4.8), 3hydroxybutyrate dehydrogenase (HBDH, EC 1.1.1.30), isocitrate dehydrogenase (IDH, EC 1.1.1.42), cytosol aminopeptidase (LAP, EC 3.4.11.1), L-lactate dehydrogenase (LDH, EC 1.1.1.27), malate dehydrogenase (MDH, EC 1.1.1.37), "malic" enzyme (ME, EC 1.1.1.40), mannose-6-phosphate isomerase (MPI, EC 5.3.1.8), nucleoside-diphosphate kinase (NDPK, EC 2.7.4.6), purine-nucleoside phosphorylase (NP, EC 2.4.2.1), dipeptidase (PEP-A, EC 3.4.13.), tripeptide aminopeptidase (PEP-B, EC 3.4.11.), proline dipeptidase (PEP-D, EC 3.4.13.), phosphoglycerate mutase (PGAM, EC 5.4.2.1), phosphogluconate dehydrogenase (6PGD, EC 1.1.1.44), phosphoglycerate kinase (PGK, EC 2.7.2.3), phosphoglucomutase (PGM, EC 5.4.2.2), superoxide dismutase (SOD, EC 1.15.1.1), L-iditol dehydrogenase (SRDH, EC 1.1.1.14), and triosephosphate isomerase (TPI, EC 5.3.1.1). The nomenclature used to refer to loci and allozymes follows Adams et al. (1987).

\section{Data analyses}

The phenetic clustering procedure of Principal Co-ordinates Analysis (PCoA) was initially used to assess the genetic affinities of all individuals sampled, without a priori reference to their morphotype. This technique uses multivariate ordination principles on a distance matrix to construct a reduced number of dimensions which account for most of the variation expressed amongst $\mathrm{N}$ points (individuals, populations, etc) in $\mathrm{N}$ dimensional Euclidean space (Pielou 1984). The resultant scores from $\mathrm{PCOA}$ for the first two dimensions are then presented visually as a scattergram, revealing the existence of any primary genetic groups and, most importantly, displaying the extent of any within-group diversity. Each PCoA was applied to a matrix of Rogers' genetic distance (Rogers 1972) between individuals and implemented using the computer program PATN (Pattern Analysis Package; Belbin 1994).

A series of four PCoAs was undertaken on the allozyme data, the first employing all 114 individuals and the others based on reduced subsets in which those individuals which fell most clearly into distinctive clusters were sequentially removed. The stepwise use of multiple PCoAs, as explained and employed by Georges and Adams (1992), is particularly suited to taxonomically complex situations where numerous genetic groups are present and thus cannot all be resolved by a single analysis. In such cases, the initial PCoA will show considerable overlap among genetic groups which belies their genuine distinctiveness in deeper dimensions. In these situations a subsequent PCoA, based only on these overlapping groups, is able to demonstrate this distinctiveness.

Having established which morphotypes merit recognition on genetic criteria, the overall genetic similarities between the taxa thus defined were quantified by calculating (a) the percentage of "fixed" differences (\%FDs; Richardson et al. 1986), allowing a $10 \%$ tolerance (i.e., the cumulative frequency of any shared alleles must not exceed $10 \%$; see Georges et al. [2002] for the rationale behind this operational definition of \%FDs), and (b) Nei's genetic distance (Nei D; Nei 1978) for each relevant pairwise comparison. For simplicity of presentation, the genetic relationships among taxa were displayed visually in a Neighbour Joining tree based on the Nei Ds. This tree was constructed using the program PHYLIP version 3.5c (Felsenstein 1993) and drawn using TREEVIEW version 1.6.0 (Page 1996).

\section{RESULTS}

A total of 46 putative allozyme loci were considered scorable in this study. The allozyme profiles of the 114 specimens at these 46 loci are presented in Appendix 2. All but seven loci were variable, and the level of genetic heterogeneity encountered far exceeds that expected for a single biological species (Thorpe 1983; Richardson et al. 1986).

Figure 3 presents the initial PCoA involving all 114 specimens, labelled according to morphotype. Seven of the 11 morphotypes displayed discrete, non-overlapping clusters, although in two instances a pair of clusters ( $L$. muelleri/L. nevinae and $L$. rhodonoides/L. kingi) abutted one another. The remaining four morphotypes (L. haroldi, L. micra, $L$. occulta and $L$. rolfei) could not be separated in the first two PCoA dimensions. A second PCoA on the individuals belonging to these four overlapping groups plus L. clara (Figure 4), revealed that all morphotypes were now diagnosable with the exception of $L$. micra versus $L$. occulta. A third PCoA using only the $L$. micra and $L$. occulta specimens indicated that these two morphotypes were also genetically distinguishable (Figure 5). Finally, separate PCoAs on each of the two groupings not fully resloved in the initial PCoA $(L$. muelleri/L. nevinae and $L$. rhodonoides/L. kingi) demonstrated the genetic distinctiveness of each of these four taxa (Figure 6 shows the latter pair).

Once stepwise PCoAs had demonstrated that all 11 species were diagnosable by their allozyme profiles, individuals were then pooled into species 


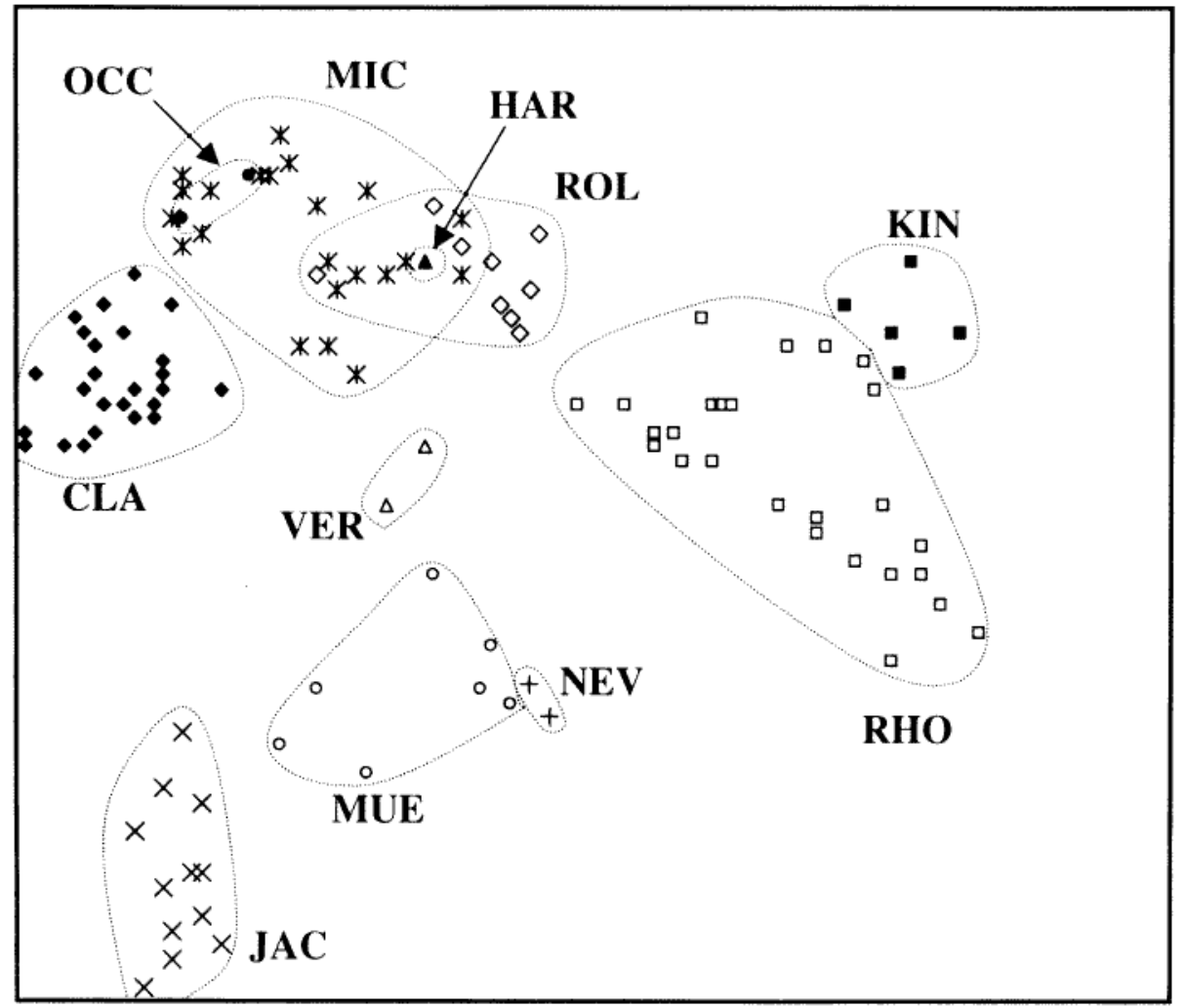

Figure 3 PCoA for all 114 specimens of Lerista included in the allozyme study. The relative PCoA scores have been plotted for the first and second dimensions, which individually explained $14 \%$ and $12 \%$, respectively, of the total multivariate variation. Legends for specimens and species: Lerista clara $(\mathrm{CLA})=\boldsymbol{\bullet} ;$. kingi $(\mathrm{KIN})=\mathbf{\square}$; L. haroldi $(\mathrm{HAR})=\boldsymbol{\Delta} ;$ L. jacksoni $(\mathrm{JAC})=\times ;$ L. muelleri $(\mathrm{MUE})=\square ;$ L. micra $(\mathrm{MIC})=*$; L. nevinae $(\mathrm{NEV})=$ $+; L$. occulta $(\mathrm{OCC})=\bullet ;$. rhodonoides $(\mathrm{RHO})=\square ; L$. rolfei $(\mathrm{ROL})=\diamond ; L$. verhmens $(\mathrm{VER})=\Delta$.

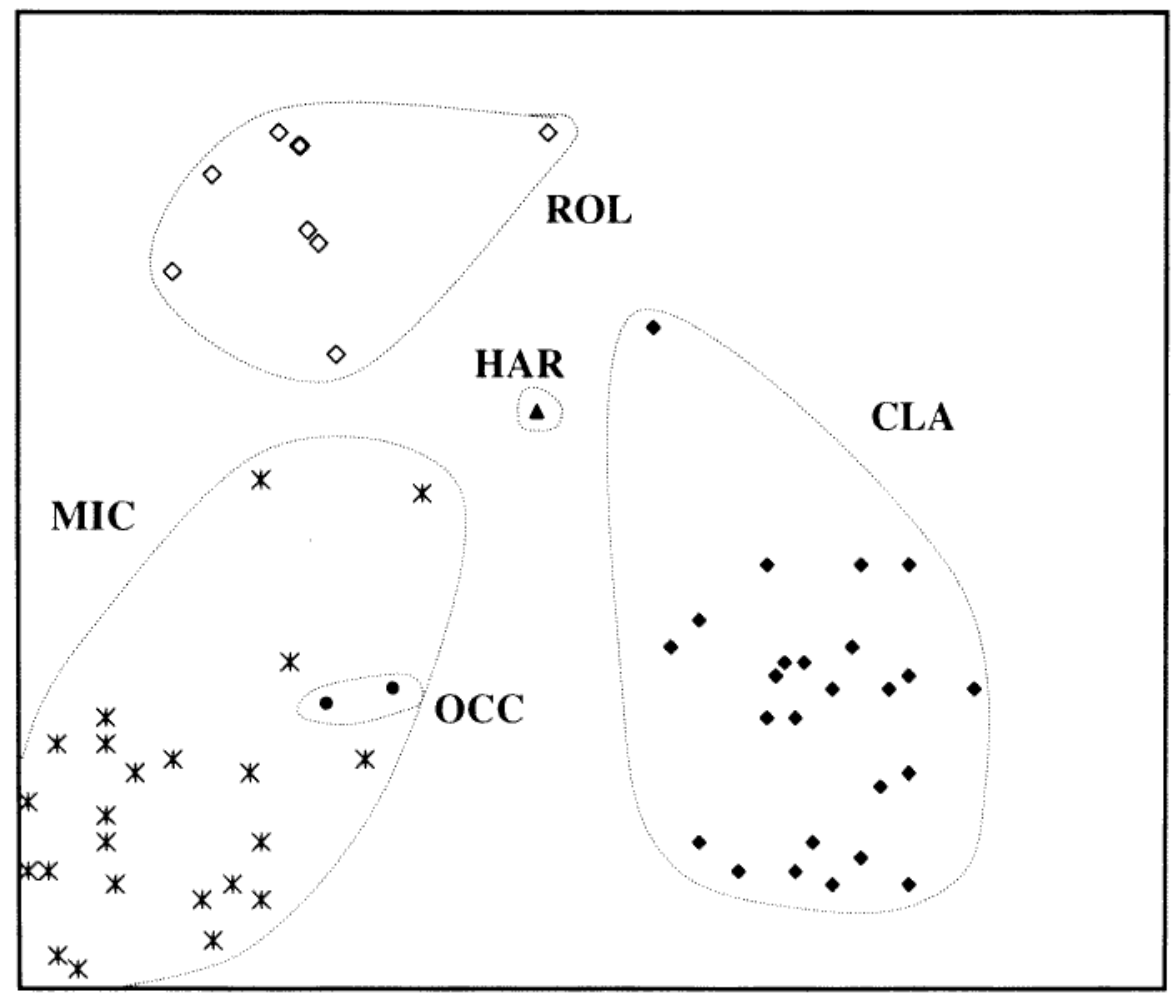

Figure 4 PCoA for the 60 specimens representing the five species Lerista clara sp. nov., L. haroldi, $L$. micra sp. nov., $L$. occulta sp. nov. and L. rolfei sp. nov. The first and second dimensions individually explained $17 \%$ and $10 \%$, respectively, of the total multivariate variation. Legends as per Figure 3. 


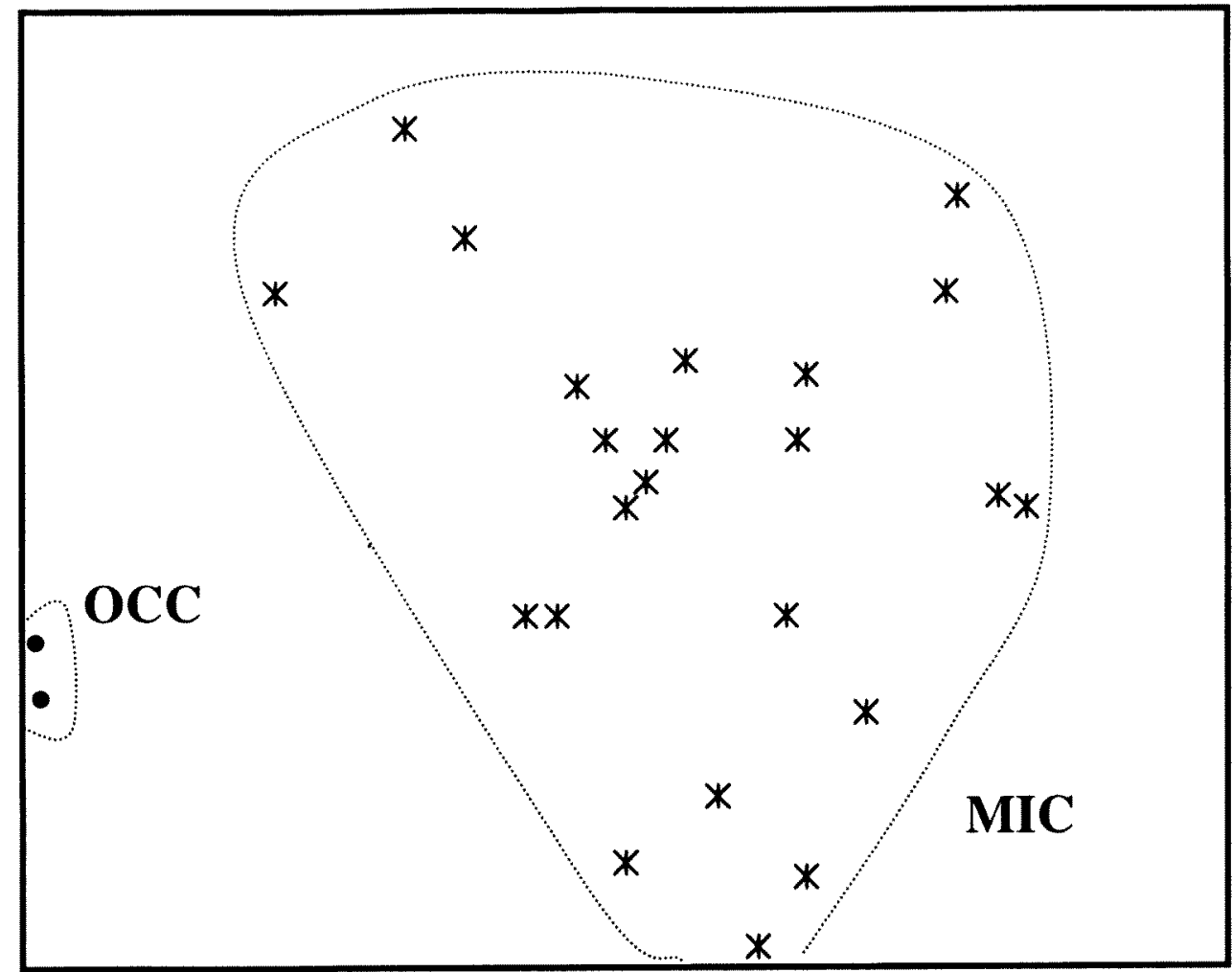

Figure 5 PCoA for the 25 specimens representing L. micra sp. nov. and L. occulta sp. nov. The first and second dimensions individually explained $16 \%$ and $11 \%$, respectively, of the total multivariate variation. Legends as per Figure 3 .

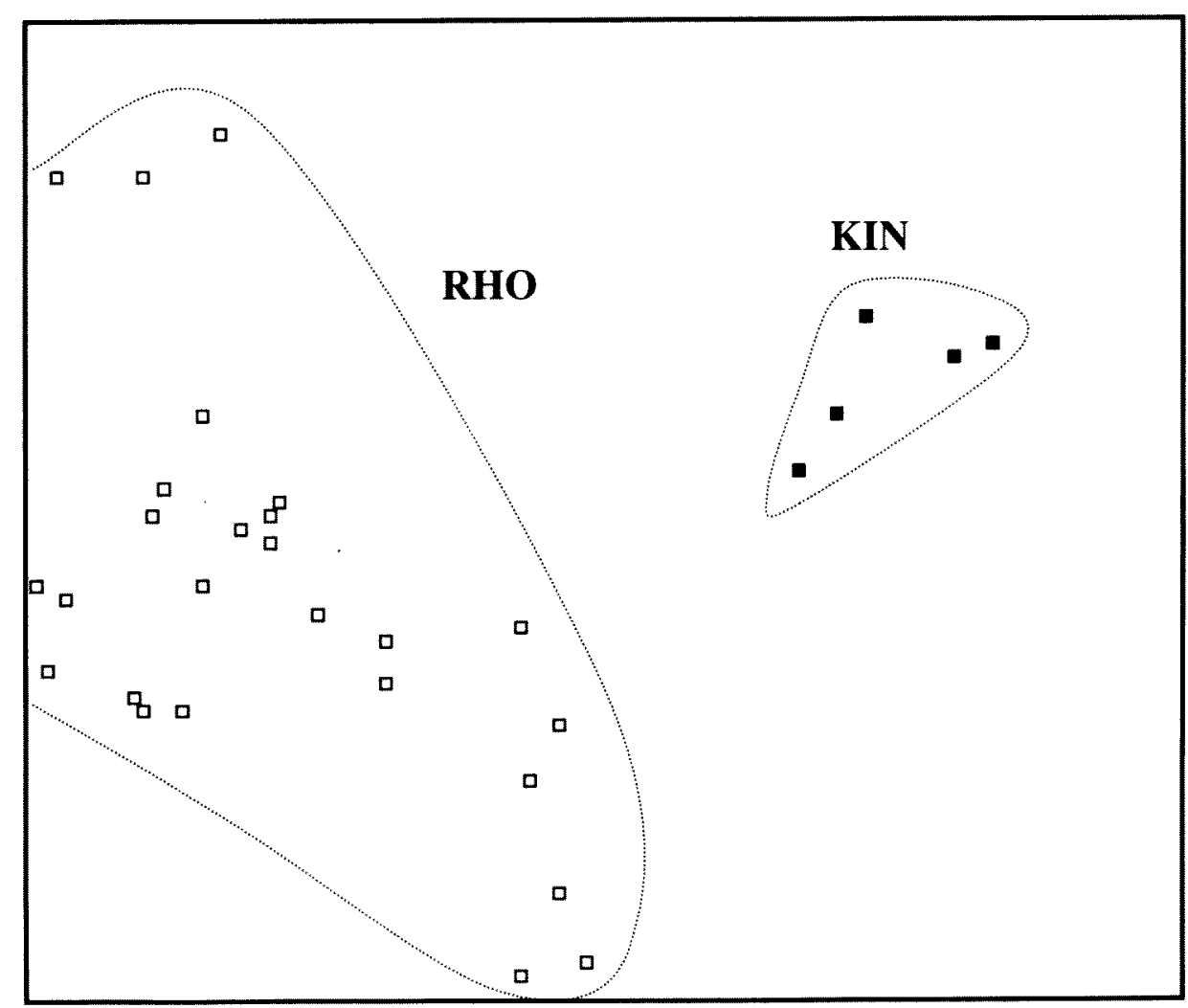

Figure 6 PCoA for the 31 specimens representing Lerista kingi sp. nov. and L. rhodonoides. The first and second dimensions individually explained $16 \%$ and $15 \%$, respectively, of the total multivariate variation. Legends as per Figure 3. 
Table 1 Allele frequencies at 39 variable loci for the 11 species identified by morphological analysis and supported by the principal co-ordinates analyses. Where a locus is polymorphic, the frequency of the more common alleles are expressed as percentages and shown as superscripts (the frequency of the rarest allele can be then be calculated by subtraction). The maximum number of haloid genomes sampled is shown in brackets. Invariant loci: Acon1, Alb, Lap, Ldh2, Np, Sod, and Tpi. Species code as per Figure 3.

\begin{tabular}{|c|c|c|c|c|c|c|c|c|c|c|c|}
\hline Locus & $\begin{array}{l}\text { CLA } \\
(50)\end{array}$ & $\begin{array}{l}\text { HAR } \\
(2)\end{array}$ & $\begin{array}{l}\text { JAC } \\
(24)\end{array}$ & $\begin{array}{l}\text { KIN } \\
(10)\end{array}$ & $\begin{array}{l}\text { MIC } \\
(46)\end{array}$ & $\begin{array}{l}\text { MUE } \\
(14)\end{array}$ & $\begin{array}{l}\text { NEV } \\
\text { (4) }\end{array}$ & $\begin{array}{c}\text { OCC } \\
\text { (4) }\end{array}$ & $\begin{array}{l}\text { RHO } \\
(52)\end{array}$ & $\begin{array}{l}\text { ROL } \\
(18)\end{array}$ & $\begin{array}{l}\text { VER } \\
\text { (4) }\end{array}$ \\
\hline Acon 2 & $c^{42}, b^{36}, d^{20}, a$ & $\mathrm{c}^{511}, \mathrm{~d}$ & $d^{58}, c$ & $c^{(4),}, d$ & $\mathrm{c}^{\mathrm{h} 7}, \mathrm{~d}^{17}, \mathrm{~b}^{17}, \mathrm{e}$ & $b^{5}, c$ & c & $c^{5 i 1}, \mathrm{~d}$ & $c^{79}, b$ & $\mathrm{c}^{72}, \mathrm{~d}^{17}, \mathrm{~b}$ & c \\
\hline$A c p l$ & a & $\mathrm{c}$ & $\mathrm{a}$ & c & $a^{48,}, b$ & $a$ & $a$ & $\mathrm{a}$ & a & $a^{89}, c$ & $\mathrm{a}$ \\
\hline Acyc & $d^{9 k}, f$ & $\mathrm{c}^{50}, \mathrm{~d}$ & $\mathrm{~d}^{75}, \mathrm{e}$ & c & $\mathrm{c}^{76}, \mathrm{~d}^{17}, \mathrm{f}^{3}, \mathrm{a}^{2}, \mathrm{~b}$ & $d^{* 6, f}$ & $\mathrm{c}$ & d & $d^{6 x}, b^{19}, c^{13}, e$ & $d^{b 1}, c$ & $\mathrm{c}^{75}, \mathrm{a}$ \\
\hline Adh1 & b & $\mathrm{b}$ & $\mathrm{b}$ & $c^{31}, b^{40}, d$ & b & $\mathrm{b}$ & $\mathrm{a}$ & b & $\mathrm{b}^{\mathrm{\alpha h}}, \mathrm{c}^{12}, \mathrm{~d}$ & $\mathrm{~b}$ & b \\
\hline Adh 2 & $\begin{array}{c}\mathrm{e}^{78}, \mathrm{c}^{12}, \mathrm{~d}^{\circ}, \\
\mathrm{a}^{2}, \mathrm{f}\end{array}$ & $\mathrm{e}$ & c & $\mathrm{c}^{70}, \mathrm{~d}^{20}, \mathrm{e}$ & $\begin{array}{c}\mathrm{c}^{+4}, \mathrm{e}^{33}, \mathrm{a}^{13}, \\
\mathrm{f}^{+}, \mathrm{d}\end{array}$ & c & $\mathrm{c}$ & e & $\mathrm{c}^{8 *}, \mathrm{~d}^{10}, \mathrm{e}$ & $e^{h \hat{i}}, c$ & $c^{50}, b^{25}, e$ \\
\hline$A k 2$ & c & c & $a^{63}, c$ & c & c & c & $b^{510}, \mathrm{c}$ & c & c & c & c \\
\hline $\mathrm{Ca}$ & b & $\mathrm{b}$ & $\mathrm{b}$ & $b$ & $b^{93}, a$ & $\mathrm{~b}$ & $\mathrm{~b}$ & b & $b^{9 s}, c$ & $\mathrm{~b}$ & $\mathrm{~b}$ \\
\hline Dia & $e^{56} f{ }^{10}, h$ & e & $\mathrm{e}^{74}, \mathrm{c}$ & $\mathrm{g}$ & $\mathrm{e}^{\mathrm{k} 7}, \mathrm{~g}^{15}, \mathrm{~d}^{4}, \mathrm{c}^{3}, \mathrm{~b}$ & $\mathrm{e}^{74}, \mathrm{c}^{14}, \mathrm{~g}$ & $f$ & $g$ & $\mathrm{~g}^{48}, \mathrm{e}^{\mathrm{lu}, \mathrm{b}}$ & $\mathrm{g}^{4 \times,} \mathrm{a}^{\mathrm{b}}, \mathrm{e}$ & $\mathrm{g}$ \\
\hline Enol & $\mathrm{b}$ & $\mathrm{b}$ & $\mathrm{b}$ & $b^{911}, a$ & $b^{98,}, c$ & b & $\mathrm{b}$ & b & b & $b^{104}, c$ & b \\
\hline Est1 & b & $\mathrm{b}$ & $\mathrm{b}$ & $b^{911}, a$ & $\mathrm{~b}^{98}, \mathrm{a}$ & b & $\mathrm{b}$ & b & $\mathrm{b}^{68}, \mathrm{a}$ & $\mathrm{b}$ & $\mathrm{b}$ \\
\hline$F d p$ & a & a & $a^{42}, b$ & a & $a^{98}, c$ & a & $\mathrm{a}$ & a & a & $a^{4,4}, c$ & a \\
\hline Fum & a & a & a & $b^{511}, a$ & $c^{2}, a^{9 / 8}$ & a & $\mathrm{a}$ & c & $\mathrm{b}^{4}, \mathrm{a}^{9+1}$ & a & a \\
\hline Gopd & $b^{40,}, c^{2}, e$ & $\mathrm{~b}$ & $\mathrm{~d}^{96}, \mathrm{e}$ & $\mathrm{b}$ & $\mathrm{b}^{\times 3}, \mathrm{c}^{15}, \mathrm{a}$ & d & d & b & $b^{* 8}, a^{8}, c^{2}, d$ & $\mathrm{~b}$ & b \\
\hline Gda & $\mathrm{b}^{*}, \mathrm{a}$ & $\mathrm{b}$ & $a^{67}, b$ & $a^{x^{* i}}, b$ & $b^{43}, e^{3}, a^{2}, c$ & $b^{3}, d^{+3}, e$ & $\mathrm{~b}$ & c & $\mathrm{b}^{-1}, \mathrm{a}$ & $\mathrm{b}$ & $\mathrm{b}$ \\
\hline Glo & $\mathrm{b}$ & $b^{501}, a$ & $\mathrm{~b}$ & $\mathrm{~b}$ & b & b & b & $\mathrm{b}$ & $\mathrm{b}$ & $\mathrm{b}$ & $\mathrm{b}$ \\
\hline Got1 & $b$ & $\mathrm{~b}$ & $\mathrm{~b}$ & b & b & $b^{43}, d$ & $\mathrm{~b}$ & b & $\mathrm{b}^{42}, \mathrm{~d}^{6}, \mathrm{c}$ & $\mathrm{b}^{94}, \mathrm{a}$ & $b$ \\
\hline Got2 & a & a & $\mathrm{a}$ & a & $\mathrm{a}$ & a & $\mathrm{a}$ & $\mathrm{a}$ & $a^{94}, b$ & $a$ & $\mathrm{a}$ \\
\hline Gpd & $c^{98}, b$ & c & c & c & c & c & c & c & $c^{36}, a$ & c & $c$ \\
\hline Gpi & $b^{80}, e^{14}, a^{2}, d^{2}, f$ & c & $e^{96}, f$ & $c^{21}, b$ & $b^{98}, f$ & $\mathrm{~b}$ & c & $\mathrm{b}$ & $b^{52}, e$ & $c^{(x)}, b^{28}, a^{6}, e$ & $\mathrm{~b}^{50}, \mathrm{c}$ \\
\hline Gsr & $\mathrm{c}^{94}, \mathrm{a}^{2}, \mathrm{~d}^{2}, \mathrm{e}$ & $\mathrm{c}$ & $c^{9 h}, a$ & $c^{(2)}, b$ & $\mathrm{c}^{48}, \mathrm{e}^{28}, \mathrm{~d}$ & $\mathrm{~d}^{64}, \mathrm{e}^{29}, \mathrm{c}$ & $\mathrm{e}$ & c & $\mathrm{e}^{57}, \mathrm{c}^{33}, \mathrm{~d}^{4}, \mathrm{a}$ & $\mathrm{c}^{22}, \mathrm{~d}^{22}, \mathrm{e}$ & $c^{75}, f$ \\
\hline Guk & $\mathrm{d}^{94}, \mathrm{a}^{4}, \mathrm{~b}$ & c & d & $\mathrm{d}$ & $\mathrm{d}^{9_{1}}, \mathrm{~b}$ & d & d & d & $\mathrm{d}^{42}, \mathrm{a}$ & $\mathrm{b}^{5 \hbar}, \mathrm{d}$ & d \\
\hline$H b d h$ & $d^{62}, b^{36}, e$ & b & $\mathrm{d}^{63}, \mathrm{~b}^{24}, \mathrm{e}$ & $b^{q_{11}}, \mathrm{a}$ & b & $d^{86}, e$ & d & $\mathrm{b}$ & $\mathrm{d}^{61}, \mathrm{~b}^{37}, \mathrm{c}$ & $b^{44}, a$ & d \\
\hline Idh1 & a & $\mathrm{a}$ & a & $\mathrm{a}$ & a & $\mathrm{a}$ & a & a & a & a & $a^{\bar{n} u}, b$ \\
\hline$L d h 1$ & a & a & a & a & $\mathrm{a}$ & $a^{93}, b$ & a & a & $\mathrm{a}$ & a & $\mathrm{a}$ \\
\hline Ldh3 & a & $\mathrm{b}$ & a & b & $a^{91}, b$ & a & $\mathrm{b}$ & a & $\mathrm{b}$ & a & a \\
\hline Mdh1 & c & c & c & c & $c^{48}, a$ & $c^{43}, b$ & c & c & $\mathrm{c}$ & c & c \\
\hline Mdh2 & $a^{46}, b$ & $\mathrm{a}$ & a & a & a & a & a & $\mathrm{a}$ & $a^{90}, b$ & a & a \\
\hline $\mathrm{Me} 2$ & $\begin{array}{l}c^{811}, e^{14} \\
b^{4}, d\end{array}$ & c & $\mathrm{c}^{96}, \mathrm{~b}$ & $\mathrm{~d}^{(1)}, \mathrm{c}^{20}, \mathrm{e}$ & $\begin{array}{c}c^{\mathrm{h}^{5},}, \mathrm{e}^{18}, \mathrm{~b}^{1.3}, \\
\mathrm{a}^{2}, \mathrm{~d}\end{array}$ & $\begin{array}{l}\mathrm{c}^{30}, \mathrm{~d}^{21} \\
\mathrm{e}^{13}, \mathrm{~b}\end{array}$ & $\mathrm{c}$ & c & $\begin{array}{c}\mathrm{e}^{48}, \mathrm{c}^{31}, \mathrm{~d}^{11} \\
\mathrm{~b}^{8}, \mathrm{~g}\end{array}$ & $\begin{array}{l}c^{56}, e^{21} \\
b^{17}, f\end{array}$ & c \\
\hline Mpi & $c^{96}, d$ & c & c & $c^{*(1)}, b$ & $c^{40}, b^{2}, d$ & c & c & c & $\mathrm{c}^{42}, \mathrm{~d}^{b}, \mathrm{~b}$ & $c^{44}, b$ & $\mathrm{C}^{75}, \mathrm{a}$ \\
\hline$N d p k$ & a & a & a & a & a & $a^{43}, b$ & a & a & a & $\mathrm{a}$ & $\mathrm{a}$ \\
\hline PepA & $\mathrm{d}^{82}, \mathrm{e}^{10}, \mathrm{~b}^{6}, \mathrm{c}$ & $\mathrm{d}$ & $\mathrm{b}$ & d & $\mathrm{d}^{\mathrm{k} 10}, \mathrm{~b}^{17}, \mathrm{e}$ & $b^{43}, d$ & $\mathrm{~b}$ & $\mathrm{~d}$ & $d^{64}, b^{23}, e^{4}, a^{2}, c$ & $\mathrm{~d}^{72}, \mathrm{~b}$ & $\mathrm{~b}$ \\
\hline РерB & $\begin{array}{c}\mathrm{d}^{6 \mathrm{H}}, \mathrm{c}^{2 \mathrm{x}} \\
\mathrm{e}^{2}, \mathrm{f}\end{array}$ & $c^{*}, \mathrm{~d}$ & $\begin{array}{c}\mathrm{d}^{75}, \mathrm{f}^{17} \\
\mathrm{~b}^{4}, \mathrm{~h}\end{array}$ & $d^{4 n}, b$ & $\begin{array}{c}d^{78}, c^{11}, f^{7} \\
e^{2}, g\end{array}$ & $d^{43}, a$ & d & $\begin{array}{c}f^{511}, b^{25} \\
d\end{array}$ & $\mathrm{~d}^{58}, \mathrm{~b}$ & $\mathrm{~d}^{\mathrm{s},}, \mathrm{c}^{\mathrm{b}, \mathrm{f}}$ & $\mathrm{d}^{75}, \mathrm{c}$ \\
\hline PepD & $\begin{array}{c}h^{74}, f^{1 x}, \\
g^{4}, j\end{array}$ & $\mathrm{f}$ & $\mathrm{h}^{96, \mathrm{c}}$ & f & $\begin{array}{c}\mathrm{d}^{41}, \mathrm{~g}^{27}, \mathrm{f}^{15}, \\
\mathrm{~h}^{15}, \mathrm{a}\end{array}$ & $\begin{array}{c}\mathrm{f}^{57}, \mathrm{~h}^{36}, \\
\mathrm{~g}\end{array}$ & $\mathrm{~h}$ & $d^{75}, e$ & $\begin{array}{c}\mathrm{f}^{+9}, \mathrm{~h}^{27}, \mathrm{~d}^{10}, \\
\mathrm{~g}^{6}, \mathrm{~b}^{4}, \mathrm{i}\end{array}$ & $\begin{array}{c}\mathrm{d}^{44}, \mathrm{f}^{22}, \mathrm{i}^{17} \\
\mathrm{~h}^{12}, \mathrm{j}\end{array}$ & $\begin{array}{c}g^{50}, f^{27}, \\
h\end{array}$ \\
\hline Pgam & a & a & $a^{88}, b$ & a & a & $a^{x+1}, b$ & a & a & $\mathrm{a}$ & a & $\mathrm{a}$ \\
\hline $6 P g d$ & $c^{7 t}, a^{12}, e^{x}, d^{2}, f$ & c & $\mathrm{e}^{5+}, \mathrm{c}$ & d & $\mathrm{e}^{\mathrm{s} 2}, \mathrm{c}^{11}, \mathrm{~d}$ & d & $c$ & $\mathrm{c}^{511}, \mathrm{e}$ & $\mathrm{d}^{\%}, \mathrm{~b}^{2}, \mathrm{e}$ & $d^{54}, f$ & $\mathrm{e}$ \\
\hline$P g k$ & b & $\mathrm{b}$ & $\mathrm{b}$ & b & b & $\mathrm{b}$ & $b^{75}, a$ & $\mathrm{~b}$ & b & b & $\mathrm{b}$ \\
\hline$P g m 1$ & $\begin{array}{c}a^{n+6}, c^{32}, 1^{k} \\
b^{2}, e\end{array}$ & $\mathrm{e}$ & d & $\mathrm{e}^{\mathrm{kx},}, \mathrm{c}$ & $\begin{array}{c}g^{43}, e^{2 x}, i^{1 !} \\
k^{4}, c^{7}, f\end{array}$ & 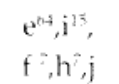 & $\mathrm{m}$ & g & $\begin{array}{l}\mathrm{e}^{\mathrm{f}^{2}, \mathrm{c}^{24}} \\
\mathrm{~g}^{7}, \mathrm{~d}\end{array}$ & $\mathrm{I}^{\mathrm{k}}, \mathrm{e}^{\mathrm{il}}, \mathrm{k}$ & $b^{75}, \mathrm{c}$ \\
\hline $\operatorname{Pgm} 2$ & b & $\mathrm{b}$ & $\mathrm{b}$ & $\mathrm{b}$ & $b^{46}, a^{2}, d$ & b & $\mathrm{b}$ & $\mathrm{b}$ & $b^{77}, c^{19}, a$ & $\mathrm{~b}$ & $\mathrm{~b}$ \\
\hline Srdh & $\begin{array}{c}\mathrm{c}^{50}, \mathrm{f}^{32}, \mathrm{~d}^{10}, \\
\mathrm{e}^{4}, \mathrm{a}^{2}, \mathrm{~g}\end{array}$ & c & c & c & $a^{54}, c$ & $\mathrm{c}$ & $c^{55}, a$ & $\mathrm{a}$ & $c^{48}, b$ & $c^{4 y}, \mathrm{~d}$ & c \\
\hline
\end{tabular}

for the calculation of allele frequencies (Table 1) and genetic distances (Table 2). There were high levels of polymorphism in most species, particularly the widespread ones (e.g., L. micra was polymorphic for 25 of the 39 variable loci; Table 1). However, each species was diagnosable from all others by fixed differences for at least one and generally many more allozyme loci (average $\% \mathrm{FD}=12.2$, range 2-30; Table 2).

Figure 7 depicts the broad genetic affinities 
Table 2 Pairwise genetic distances among the 11 species examined in the allozyme study. Lower left triangle =\%FDs; upper right triangle $=$ Nei Ds. Species code as per Table 1 .

\begin{tabular}{lccccccccccc}
\hline & CLA & HAR & JAC & KIN & MIC & MUE & NEV & OCC & RHO & ROL & VER \\
\hline CLA & - & 0.141 & 0.134 & 0.233 & 0.072 & 0.127 & 0.252 & 0.140 & 0.125 & 0.092 & 0.118 \\
HAR & 11 & - & 0.276 & 0.138 & 0.156 & 0.274 & 0.299 & 0.253 & 0.181 & 0.139 & 0.227 \\
JAC & 7 & 20 & - & 0.303 & 0.166 & 0.117 & 0.205 & 0.269 & 0.181 & 0.190 & 0.150 \\
KIN & 11 & 9 & 22 & - & 0.169 & 0.244 & 0.293 & 0.268 & 0.095 & 0.132 & 0.195 \\
MIC & 2 & 9 & 7 & 7 & - & 0.130 & 0.240 & 0.114 & 0.107 & 0.072 & 0.089 \\
MUE & 11 & 22 & 9 & 17 & 7 & - & 0.208 & 0.281 & 0.103 & 0.143 & 0.141 \\
NEV & 20 & 24 & 15 & 22 & 15 & 15 & - & 0.422 & 0.202 & 0.266 & 0.191 \\
OCC & 13 & 22 & 22 & 22 & 4 & 26 & 30 & - & 0.222 & 0.151 & 0.211 \\
RHO & 7 & 13 & 11 & 2 & 4 & 7 & 13 & 17 & - & 0.089 & 0.123 \\
ROL & 7 & 9 & 11 & 2 & 2 & 7 & 17 & 11 & 2 & - & 0.100 \\
VER & 9 & 17 & 11 & 11 & 4 & 13 & 15 & 17 & 4 & 7 & - \\
\hline
\end{tabular}

among the 11 species, based on the Nei D values (average Nei $\mathrm{D}=0.181$, range $0.072-0.422$; Table 2). The lack of any long basal branches indicates that no obvious genetic dichotomies were evident within the L. muelleri group based on the allozyme data. High levels of within-species variation coupled with comparatively low levels of between-

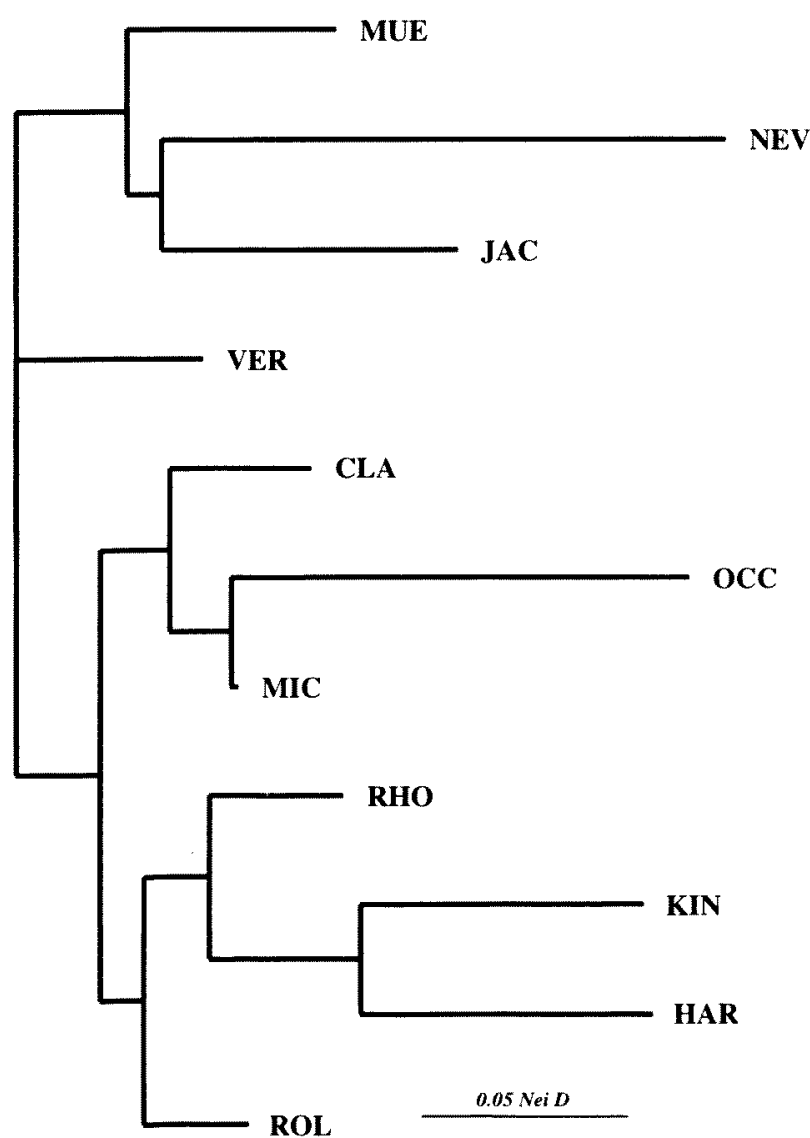

Figure 7 Neighbour joining tree depicting the genetic relationships amongst the 11 species within the Lerista muelleri species group based on allozyme data. Species legends as per Figure 3. species divergence, as demonstrated by this species group, typically preclude the use of allozyme data for phylogenetic reconstruction (Richardson et al. 1986).

\section{KEY TO SPECIES}

A key dealing with a large number of species which uses many couplets to identify a specimen, treats all species as sympatric. Although there are 13 species described here, the greatest number of sympatric $L$. muelleri species group members in a geographic area is far fewer. The coastal plains from Onslow northeast to the vicinity of Port Hedland are particularly rich. While the zone supports six species, to date, no more than two have been found at any one locality. On the Burrup peninsula, for example, there are two species recorded ( L. jacksoni and $L$. clara) with the (unlikely) possibility that $L$. muelleri, $L$. nevinae, $L$. verhmens or $L$. rhodonoides may also occur there. Lerista rhodonoides is easily eliminated because of its fused frontoparietals, $L$. muelleri by the fusion of the second supraciliary with the first supraocular, while $L$. nevinae, $L$. jacksoni and L. clara are easily distinguished by their markedly different colour patterns, leaving $L$. verhmens as perhaps the only non-trivial identification problem.

Five species occur in the hinterland of the upper west coast: L. clara, L. micra, L. occulta, L. rhodonoides and $L$. rolfei. Of these five species, $L$. rhodonoides is easily recognisable because of the fused frontoparietals, $L$. clara is readily distinguishable by its broad upper lateral stripe and immaculate flanks and belly, and the distinctive hiatus between the lower margin of the upper lateral stripe and the beginning of the lateral pattern identifies $L$. rolfei in most instances. This leaves $L$. micra and L. occulta as the only problematic taxa to discriminate. Lerista micra almost always has four 
supraciliaries (occasionally three), while $L$. occulta usually has five supraciliaries (occasionally four). The only signficant difficulty in this region therefore is correctly identifying the occasional $L$. occulta that possesses only four supraciliaries.

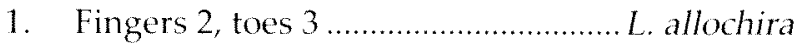
Fingers and toes 3 2

2. Frontoparietals fused ................................. 12 Frontoparietals paired 3

3. Supraciliaries $1+2$ (second supraciliary fused to first supraocular) L. muelleri

Supraciliaries 4 or 5 , rarely 3 , in an uninterrupted series. 4

4. Supraciliaries 5 .......................................... 5

Supraciliaries 4 9

5. Upper lateral stripe broad, usually solid and straight-edged; belly pearly white, never pigmented.... L. clara

Upper lateral stripe narrow or absent, if narrow distal margin not straight-edged; belly yellowish, often pigmented

6

6. A zone of unpigmented scales below upper lateral stripe L. rolfei

All scales below upper lateral stripe pigmented (spots, flecks).... 7

7. Dark purplish-brown skinks with little or no upper lateral stripe; lineopunctate stripes on back and flanks prominent; paravertebrals 62-76. L. occulta

Brown, grey or olive skinks with a prominent upper lateral stripe in moderate or strong contrast with back and lower flanks; paravertebrals $65-88$ .. 8

8. Specimens south of the Murchison River; abdomen usually pigmented (dots); subcaudals without dots .................... L. kingi

Specimens from Pilbara; abdomen without spots; subcaudals with spots ...... L. verhmens

9. Pale creamy-yellow skinks lacking continuous or lineopuctate stripes L. haroldi

Yellowish, greyish, brownish or olive skinks with continuous or lineopunctate stripes .. 10

10. Back yellowish with a prominent continuous paravertebral stripe ..................... L. nevinae

Back brown, olive or grey without a continuous paravertebral stripe

11. Pilbara species; paravertebrals 69-89

L. jacksoni

Upper west coast species; paravertebrals 58-92

L. micra
12. Margins of dorsal rows one and two dark grey; 18-22 midbody scales ............... L. amicorum

Margins of dorsal rows one and two not dark grey; midbody scales 20 ....... L. rhodonoides

\section{TAXONOMY}

Storr et al. (1981) placed L. muelleri in the $L$. elegans species group which included $L$. christinae, $L$. distinguenda, L. elegans, $L$. frosti, L. microtis, $L$. muelleri, $L$. separanda, $L$. terdigitata and $L$. xanthura. Greer (1990) used scale characters and phalangeal formulae to divide the $L$. elegans group of Storr and colleagues to define a $L$. orientalis species group which comprised L.muelleri, L. orientalis, L. taeniata and L. xanthura, although, at this stage we cannot be sure what his $L$. muelleri really was. The burgeoning genus forced more amendments. Storr et al. (1999) recognised 12 species groups. Lerista muelleri was placed in the $L$. elegans species group together with $L$. allochira, L. chistinae, L. distinguenda, L. elegans, L haroldi, L. lineata, L. orientalis, L. separanda, L. taeniata and L. xanthura.

Genetic data (Kendrick 1991; Aplin, Adams and Cowan, unpublished data; Donnellan, unpublished data) suggest Lerista has, in the past, been subdivided too finely (Aplin and Smith 2001). The genetic data indicate that the $L$. muelleri species group should only include L. allochira, L. muelleri, $L$. separanda, $L$. xanthura and possibly also $L$. haroldi, L. orientalis and $L$ taeniata (Aplin and Smith 2001). The description of nine new species here, in addition to L. ingrami and L. zonulata described by Storr (1991b) potentially more than doubles the number of species in the $L$. muelleri species group. Ascertaining whether these species, together with underscribed $L$. muelleri-like species in eastern Australia, belong in an expanded $L$. muelleri species group will probably not be known until more genetic data are avialable.

If $L$. orientalis, $L$. separanda, $L$. taeniata and $L$. xanthura, together with the thirteen species described or redescribed here, together with the two species described by Storr (1991b) belong in the L. muelleri species group it can be defined as follows (data from Greer 1991; Storr 1976, 1991b; this paper).

Very small to large semifossorial skinks ( $L$. ingrami SVL up to $36 \mathrm{~mm}$, L. verhmens up to 50 $\mathrm{mm}$ ) with elongate to moderately elongate bodies. Mean forelimb length $8.5 \%$ (L. zonulata) to $13.9 \%$ ( $L$. occulta and $L$. verhmens) of SVL and mean hindlimb length $25 \%$ (L. muelleri) to $34 \%$ ( $L$. orientalis) of SVL. Eyelid immovable (a spectacle). Digits $4+4,3+3,2+3$. Midbody scale rows 18-22.

Nasals large, rarely narrowly separated, usually in short to moderate contact. Prefrontals widely 
separated. Frontoparietals in long contact or fused. Supraoculars three, first two in contact with frontal Supraciliaries three four or five in a complete or interrupted series. Loreals two, anterior the larger. One or two presuboculars. Upper labials six. Nuchals zero to five on either side of vertebral line. Primary temporals one; secondary temorals two, upper much the larger and overlapped by the lower.

Dorsum usually olive brown, brown or creamy white. Usually pattern on the first two rows of dorsal scales, absent or reduced to a dot, dash or oblong on each scale. Pale whitish dorsolateral stripe moderately strong, weak or absent. Blackishbrown upper lateral stripe completely solid, solid at its upper edge, fragmented at lower edge. Lower flanks and venter spotted with blackish-brown of various intensity to immaculate pearly white.

Members of this species group are litter dwellers. Most species are found in the copious beds of leaf litter under Acacia on sandy loams. Some are found in the limited litter under rocks. Other species have been found in Triodia on red sand dunes while one species is only known from a white sand dune immediately adjacent to the sea and another appears to be confined to heavy cracking clays associated with coolibah (Eucalyptus victrix) flats.

The following descriptions present pooled data for meristic and mensurable characters for each species. Appendix 1 tabulates the data for those characters for males and females, and the pooled data for each species.

\section{Lerista allochira Kendrick 1989}

Lerista allochira Kendrick, P.G. 1989. Two new species of Lerista (Lacertilia:Scincidae) from the Cape Range and Kennedy Range of Western Australia. Journal of Herpetology 23: 350-355 [350].

\section{Diagnosis}

Distinguished from all other members of the $L$. muelleri complex by having two (rather than three) fingers and one presubocular (rather than two).

\section{Description}

SVL 22-40mm (N 21, mean 32.2). TL 31-37mm (N 4, mean 34.7) TL\%SVL 109.1-140.9 (N 4, mean 118.7). FL 2.5-3.5 mm (N 21, mean 3.1). FL\%SVL 6.9-13.6 (N 21, mean 9.8). HL 4.5-7.5 mm ( $\mathrm{N} 21$, mean 6.2). HL\%SVL 16.2-29.5 (N 21, mean 19.5). Lamellae under longest toe 5-15 ( N 17, mean 11.9), under shortest toe 3-4 (N 18, mean 3.8)

Nasals in short to moderate contact (mean of index 3.0). Prefrontals widely separated. Frontoparietals fused. Interparietal free. Supraoculars three, the first two in contact with the frontal. Supraciliaries four, the third the largest, first and fourth smallest. Loreals two. One presubocular. Upper labials six. Nuchals two to six (N 20, mean 4.8). Paravertebrals 71-85 (N 20, mean 75.7). Midbody scale rows 20 (once 22 ).

Back (scale rows one to three) bronze-brown, the dark lineopunctate pigment on scale rows oneand two reduced to intermittent flecks. Dorsolateral stripe absent. Upper lateral stripe reduced to a row of spots on lateral part of scale row three and barely distinguishable from spots on scale rows 4-10 (i.e. pigmentation on venter consistent with that of the flanks). Chin and throat heavily scalloped brown.

\section{Distribution \\ North West Cape, Western Australia (Figure 8).}

\section{Remarks}

Kendrick (1989) counted paravertebrals from the posterior edge of the parietals to the posterior margin of the thigh rather than from the posterior edge of the parietals to immediately opposite the cloaca on the dorsal surface, as is the case in this work. This is reflected in Kendrick's lower range on paravertebral counts (67-81 versus $71-85)$ and a slightly lesser mean (75.0 versus 75.7$)$. Holotype figured by Kendrick (1989).

\section{Material examined}

$14 \mathrm{~km}$ SSW Tantabiddi Well (82523), Yardie Creek $(89806,95720-4), 4 \mathrm{~km}$ E of mouth of Yardie Creek (89807-8), Mandu Mandu Gorge (95712-6), Cape Range National Park (102847), 3km SW Vlaming Head (116698, 116910-11, 117231, 132456-60), 3km SSW Learmonth Airstrip $(145199,145201)$.

\section{Lerista amicorum sp. nov.}

\section{Holotype}

Western Australian Museum R158235, a female (SVL 49, tail 48) collected at $33.6 \mathrm{~km}$ SE Roy Hill at 22 $2^{\circ} 4^{\prime} 34^{\prime \prime} \mathrm{S} 119^{\circ} 43^{\prime} 50^{\prime \prime} \mathrm{E}$ by R. Teale on 8 July 2004.

\section{Paratypes}

Between Nullagine and Roy Hill (68366-7), 30.8 km SE Roy Hill (158217-8, 158229, 158233, 1582613), 33.6 km SE Roy Hill (158223), 41.4 km (158230), $26.6 \mathrm{~km}$ SE Roy Hill (158250), Old Talawana HS (40170-1), Poonda (22641-2, 28438-40), Randall Well (125600-01).

\section{Diagnosis}

Distinguished from members of the L. muelleri species group of Western Australia with paired frontoparietals (L. clara, L. haroldi, L. jacksoni, $L$. kingi, L. micra, L. nevinae, L. occultus, L. rolfei and $L$. verhmens) by having the frontoparietals fused. Distinguished from $L$. allochira by having three fingers (two in allochira) and from L. rhodonoides 
by sometimes having 18 or 22 midbody scale rows, dorsal scale rows dark-edged and a bright yellow tail (the tail of $L$. rhodonoides is usually brownish, at most with a tinge of yellow).

\section{Description}

SVL 39-49 (N 21, mean 43.2). TL 49-55 (N 9, mean 52.0). TL\%SVL 100.0-133.3 (N 9, mean 121.4). FL $4.0-5.0 \mathrm{~mm}$ ( N 21, mean 4.4). FL\%SVL 8.2-12.2 (N 21, mean 10.1). HL 7.5-10.5 mm (N 21, mean 9.4). HL\%SVL 17.4-25.6 (N 21, mean 21.9). Lamellae under middle finger $5-10$ ( $N$ 19, mean 7.3), under longest toe 13-18 (N 20, mean 14.8), under shortest toe $3-5$ (N 20, mean 4.2).

Nasals just touching, in moderate or moderately long contact (mean of index 2.0). Prefrontals widely separated. Frontoparietals fused. Interparietal free. Supraoculars three. Supraciliaries five, the second and fourth the smallest. Loreals two, anterior the larger. Presuboculars two. Upper labials six. Nuchals two to six (N 12, mean 4.9). Paravertebrals 68-87 (N 22, mean 76.8). Midbody scale rows 18 (1), $20(14)$ or $22(7)$.
Scale rows one and two dusky grey, their dark pigment a series of spots, streaks or oblongs. Margins of scales darker grey. On medial third of dorsal row three, a suggestion of an irregular lineopunctate row of spots. Pale dorsolateral stripe moderately strong. Upper lateral stripe varies in width and intensity being narrow and almost solid blackish-brown for the medial third of scale row four or broad (as wide as dorsal row four) but the dark pigment confined to sutures between scales. Scale rows five to eight dusky, with a prominent dark spot at the junction of each scale (most pigment at the anterior of each scale). Belly creamywhite with occasional dark spots. Subcaudals spotted. Living specimens have very bright yellow tails.

\section{Distribution}

Floodplain of the upper Fortescue River from Weeli Wolli in the west, east to Neds Creek Station (Figure 8).

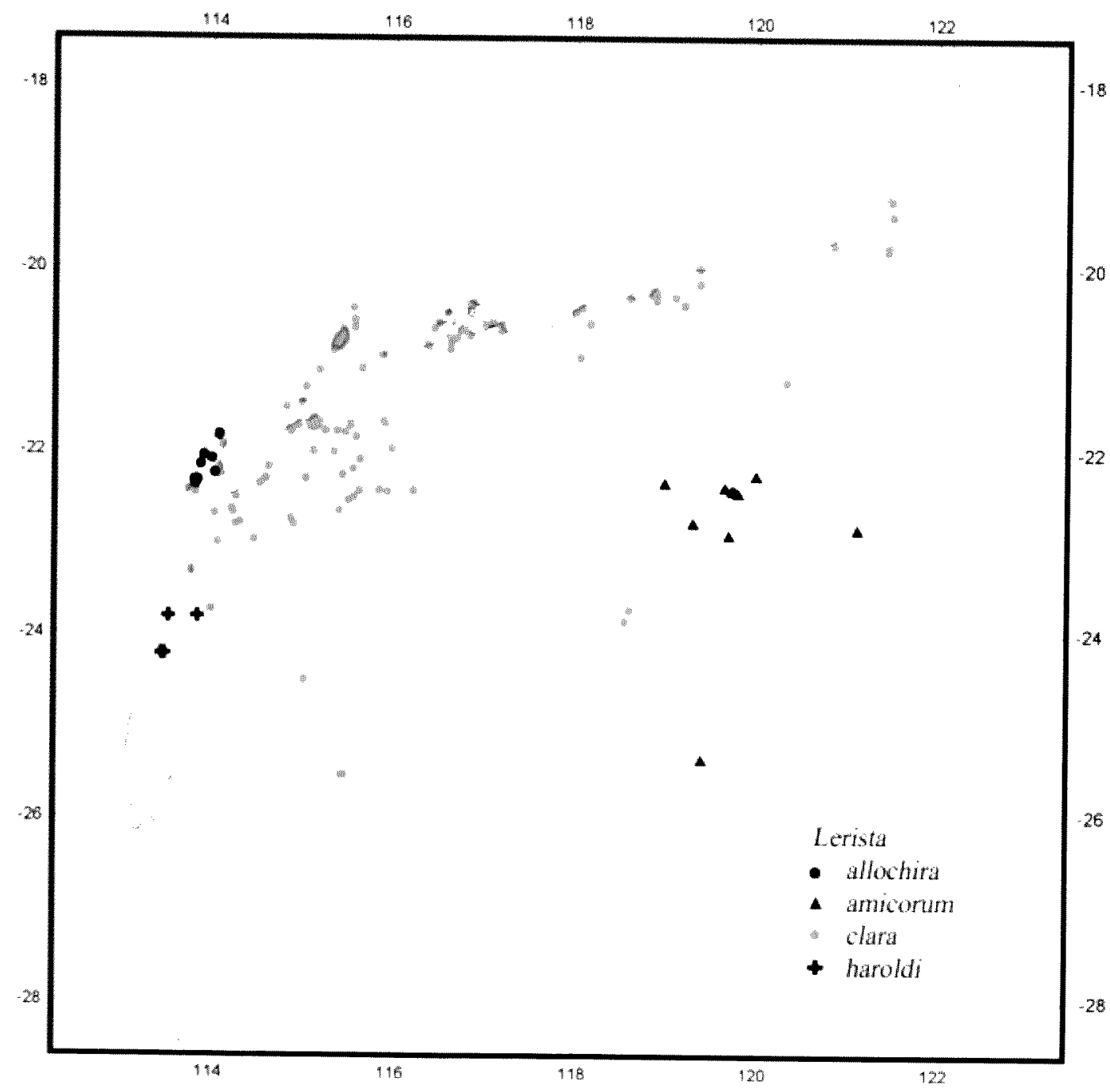

Figure 8 Distribution of Lerista allochira, L. amicorum sp. nov., L. clara sp. nov. and L. haroldi. 


\section{Remarks}

The preferred habitat of L. amicorum seems to be alluvial plains, while that of $L$. verhmens is found in rocky habitats.

\section{Etymology}

Two friends and stalwarts of the Western Australian Museum, W.H. (Harry) Butler and A.M. (Athol) Douglas collected the original specimens in 1964. Suspecting they were a new species the two evanescent rivals arrived very early one morning at the Herpetology laboratory at the Western Australian Museum, almost coincidentally, breathless, and each with part of the Poona series listed above [and clearly trying to claim the kudos for the discovery of a suspected new species]. Glen Storr, then Curator, assured them the specimens were only examples of $L$. muelleri, but facetiously suggested that should the specimens ever prove to be a new species he would call it amicorum (Latin for 'of the friends').

\section{Lerista clara sp. nov.}

Figures 9 and 10

\section{Holotype}

Western Australian Museum R135537* a male (SVL $37 \mathrm{~mm}$, TL $47 \mathrm{~mm}$ ) collected on Urala Station, Western Australia at $21^{\circ} 47^{\prime} 22^{\prime \prime} \mathrm{S}, 114^{\circ} 52^{\prime} 04^{\prime \prime} \mathrm{E}$ by R.A. How and J. Dell on 25 November 1998. Collected on a red sand dune where Triodia was dominant.

\section{Paratypes}

Mainland Localities: Anna Plains (27989), Anna Plains HS (59003), 16km S Anna Plains (114568-9*), Mandora HS (106256), Lesley Salt Field (113013-4, $113034,113069,113075)$, Port Hedland (100811), Six Mile Creek, Port Hedland $\left(114557^{*}\right)$, Strelley River (31041) Cape Lambert (68287-8, 135299, 135301, $135303,135307-8,135326,135330-3)$, Cossack (18535), Burrup Peninsula (132577-9*, 132580) "Melbourne" (presumably Nichol Bay) (ZMB 10063), $6 \mathrm{~km} \mathrm{~S} \mathrm{Nichol} \mathrm{Bay} \mathrm{(17023-4),} \mathrm{Myaree} \mathrm{Pool}$ (61568), Koodarrie HS (85101-4), near Exmouth (31439), 2 km NE Yanrey (81069), 40 km NNW Mt Minnie HS (80390-1), Old Onslow (81072), Carrawella (80339-41), $10 \mathrm{~km}$ S Onslow (127508*, 127511, 127516), Cane River (139435), Urala Stn (112502, 129012*, 132202, 132212, 132224, 132230-2, $\left.132236,132238,135474,135485,135488,140979^{*}\right), 3$ km S Vlaming Head $(116808,116809) 2 \mathrm{~km}$ ESE Minderoo (95667, 95678), 65 km NNE Ningaloo (95717), 28km S Exmouth (116418, 116563-5*, 116566), $26 \mathrm{~km} \mathrm{~S}$ Exmouth (116658), near Learmonth (151301), Learmonth (141701*), $3 \mathrm{~km}$ SSW Learmonth $\left(145198^{*}, 145200\right)$, Cape Range (104457), Koodarrie HS (81070, 81374), Yardie Creek (51017), 10 km NE Mt Murray (85176), 22 km NNW
Giralia HS (60960), Nanutarra HS (80496, 85060-77, 85279), $15 \mathrm{~km} \mathrm{~N}$ Uaroo HS (85157), Bullara HS (89918), $1 \mathrm{~km} \mathrm{~W}$ Bullara HS (89604), Yanrey Stn (151299), 9 km NW Barradale RH (80239), Marilla HS (63700), Minga Bore (116848-9*, 116851-2*, 116853), $20 \mathrm{~km} \mathrm{NE} \mathrm{Waroora} \mathrm{(81197),} 14 \mathrm{~km} \mathrm{SSW}$ Turee Creek HS (95653), 28 km SSW Turee Creek HS (106157), Meentheena $\left(139217^{*}\right), 15 \mathrm{~km} \mathrm{~N}$ Minilya (116567-70*).

Island localities: Legendre 1. (14361-2, 139343-4, 139346, 139348), Keast I. (84907-8), Brooke I. (102338), Rosemary I. (14531, 37395), Enderby I. (82918), Bridled I. (89504), Varanus I. (117694-5), Barrow I. $(29041,47856,48889-94,48974-6,119559-$ 62, 119570-3, 119577-8, 119616-22, 119631-9, 1196402), North Sandy I. (60493), Thevenard I. (27988, 103258), Eaglehawk I. (84909-14).

\section{Diagnosis}

Distinguished from members of the L. muelleri species group in Western Australia with fused frontoparietals (L. allochira, L.amicorum and L.rhodonoides) by having paired frontoparietals. Distinguished from other Western Australian members of the species group with paired frontoparietal as follows: from $L$. haroldi, $L$. jacksoni, L, micra, L. muelleri and L.nevinae by having five supraciliaries $(1+2$ in $L$. muelleri, four, very rarely three in $L$. haroldi, L. jacksoni, $L$, micra and $L$. nevinae). Four species ( $L$. kingi, $L$. occulta, $L$. rolfei and $L$. verhmens) like $L$. clara, have five supraciliaries but differ from $L$. clara in having at least some dark pigment on the lower flanks and venter (immaculate opalescent white in L. clara).

\section{Description}

SVL 20-49mm (N 198, mean 35.6). TL 23-58mm (N 41, mean 45.1). TL\%SVL 109.8-170.0 (N 41, mean 129.3). FL 2.5-5.5 mm (N 151, mean 4.3). FL\%SVL 7.3-20.0 (N 151, mean 12.2). HL 5.5-12.0 mm (N 151, mean 8.5). HL\%SVL 17.1-35.4 (N 151, mean 24.2). Lamellae under middle finger 6-12 (N 127, mean 8.3), under longest toe 11-20 ( $\mathrm{N} \mathrm{134,} \mathrm{mean}$ 15.8 ), under shortest toe $3-7$ (N 133, mean 4.6).

Nasals just touching, in moderate or moderately long contact (mean of index 3.3). Prefrontals widely separated. Frontoparietals and interparietal free. Supraoculars three. Supraciliaries five, the second and fourth the smallest. Loreals two, anterior the larger. Presuboculars two. Upper labials six. Nuchals 0-9 (N 155, mean 4.8). Paravertebrals 6583 (N 170, mean 74.1). Midbody scale rows 20 .

Scale rows one and two grey, olive or light brown each with a feeble series of lineopunctate dots, sometimes the suggestion of a third series of dots on scale row three when the medial edge of the blackish-brown upper lateral stripe is isolated from the main body of the upper lateral stripe. 


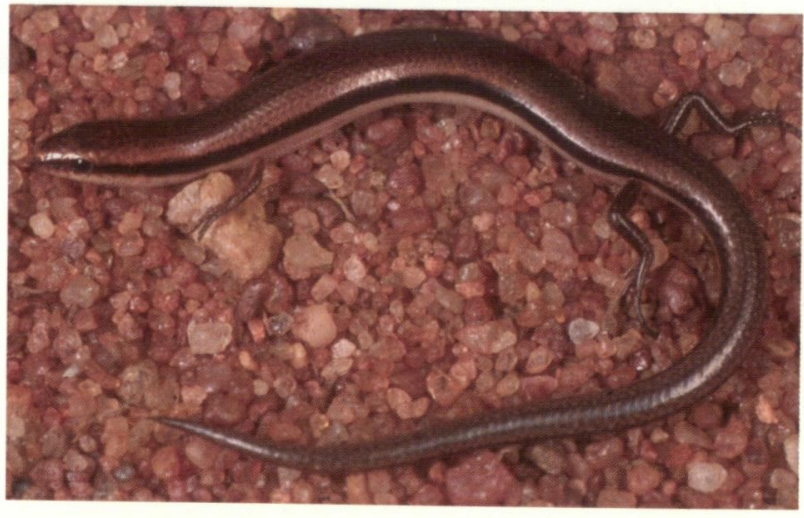

Figure 9 A Lerista clara sp. nov. from reddish soils (15 $\mathrm{km}$ north west of Barradale). Photograph G. Harold.

Dorsolateral stripe moderately well defined in brown-backed specimens, ill defined (broad and diffuse) in grey and olive-backed specimens. Upper lateral stripe commences on the lateral third of scale row three, covers all of scale row four and up to half of scale row five. Remainder of scale row five and scale rows six-ten, immaculate pearly-white. Some black pigment in the form of rows of dots or smudges sometimes present on scale rows sixeight; most prominent posteriorly, usually progressing forward to mid-trunk, sometimes to axilla, rarely to ear or face. Subcaudals immaculate.

\section{Distribution}

The coast and hinterland from Anna Plains in the north and south to Burrup Peninsula, including many Pilbara islands (Figure 8). Also from Burrup Peninsula south to North West Cape.

\section{Remarks}

At an early stage of this study it was thought $L$. clara might comprise two taxa: a small, olive or whitish-backed form (when the dorsolateral stripe is broad and diffuse and the upper lateral stripe narrow) found on the mainland from Anna Plains south-west to Burrup peninsula and a number of the Pilbara islands (Figure 10), and a larger, light brown or tan-backed form with a narrow dorsolateral stripe and a broad blackish-brown upper lateral stripe found further south and inland (Figure 9). At first, the significant size difference between the coastal grey-olive and inland browntan populations seemed to support this hypothesis, but a re-examination of the specimens and inspection of the breeding data indicate that the sample of the olive-grey-backed coastal morph was dominated by a large sample of small individuals taken from pit fall traps in December. Breeding adults (presence of turgid testes or enlarged follicles) have been collected on Barrow Island in September and October, so it is reasonable to

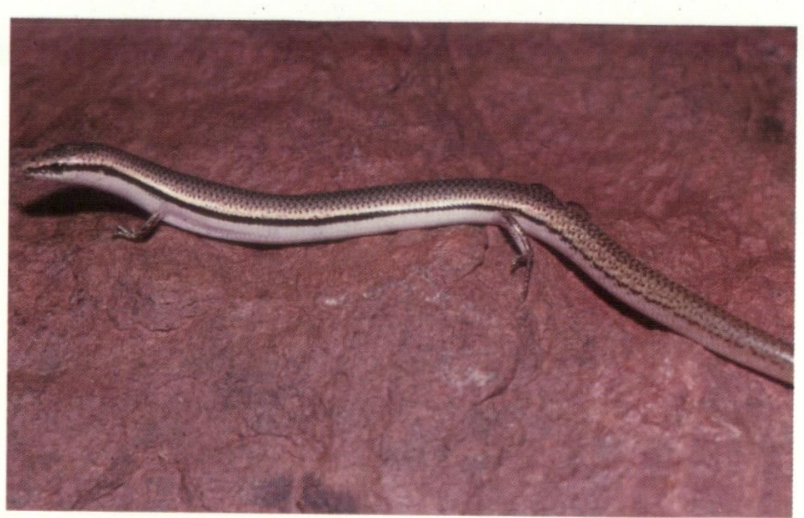

Figure 10 A Lerista clara sp. nov. from white coastal sands (Point Sampson). Photograph M. Peterson.

assume the coastal sample's mean size is skewed by the large number of juveniles.

Ecological data indicate that the grey, olive and whitish individuals with reduced pigment are generally found on white sands, including coastal dunes and the brown or tan individuals on reddish dunes and sandy loams (cf. Figures 9 and 10).

About $30 \%$ of specimens are immaculate from the ventral portion of scale row five to scale row ten (mid ventral). The presence or absence of dark pigment on the posterior mid and lower flanks is not a sexual character (males and females may or may not have lower flank pigment), nor is it a juvenile character since some small individuals (25-28 mm) have lower flank pigment while others do not.

Not included in the paratypes of this new species are five specimens (R120302, 121301-02, 122045, $123274,123261)$ from the Kennedy Range at $24^{\circ} 30^{\prime} 04.3^{\prime \prime S}, 115^{\circ} 01^{\prime} 03.4^{\prime \prime E}$ (site KE2, Carnarvon Basin survey). Although the meristics and measurements of these specimens are within the ranges of those for $L$. clara, the single live specimen seen by LAS (a juvenile) had a bright green tail which is unique in Lerista. The tails of Lerista are yellowish or reddish, juveniles often quite reddish. These specimens are not that well preserved, nevertheless, they appear more slender than clara of similar SVL's. Aplin and colleagues indicate that the only member of this series for which tissue was available (R123261) was allozymically distinctive from three other $L$. "muelleri" forms identified in the Carnarvon Basin (L. micra, L. occulta and L. rolfei as recognised here) but lack of tissue samples from other individuals from this population preclude direct comparison with $L$. clara in this study.

\section{Etymology}

Latin for clear, alluding to sharp-edged prominent upper lateral stripe which contrasts strongly with the white flanks. 


\section{Lerista haroldi Storr, G.M. 1983}

Lerista haroldi Storr, 1983. Two new lizards from Western Australia (genera Diplodactylus and Lerista). Records of the Western Australian Museum 11: 59-62 [61].

\section{Diagnosis}

Distinguished from members of the $L$. muelleri species group in Western Australia with fused frontoparietals ( $L$. allochira, L.amicorum and L.rhodonoides) by having paired frontoparietals. Distinguished from other Western Australian members of the species group with paired frontoparietal and $1+2$, four or five supraciliaries $(L$. clara, L. jacksoni, L. kingi, L. muelleri, L, micra, $L$ nevinae, $L$. occulta, $L$. rolfei and $L$. vehmens) by the lack of lateral or dorsal pattern (dorsal and upper lateral pattern present in L. clara, L. jacksoni, $L$. kingi, $L$. muelleri, $L$, micra, L.nevinae, $L$. occulta, $L$. rolfei and $L$.vehmens).

\section{Description}

SVL $18-40 \mathrm{~mm}$ ( $\mathrm{N} 5$, mean 33.8). TL $45 \mathrm{~mm}$, $118.4 \%$ of SVL (one specimen). FL $3.5-5.0 \mathrm{~mm}$ (N 5, mean 4.2). FL\%SVL 9.2-14.3 (N 4 mean 11.6). HL 8.0-10.0 mm (N 5, mean 8.8). HL\%SVL 21.0-25.0 (N 4 , mean 23.1). Lamellae under middle finger 7-8 ( N 2 , mean 7.5), under longest toe 13-14 ( $\mathrm{N} \mathrm{4}$, mean $13.5)$, under shortest toe $4(\mathrm{~N} 2)$.

Nasals just touching, in moderate or moderately long contact (mean of index 3.0). Prefrontals widely separated. Frontoparietals and interparietal free. Supraoculars three. Supraciliaries four, the second and fourth the smallest. Loreals two, anterior the larger. Presuboculars two. Upper labials six. Nuchals two to five (N 3, mean 3.7). Paravertebrals 69-81 (N 4, mean 73.2). Midbody scale rows 20.

Head trunk and tail creamy yellow, without dorsolateral and upper lateral stripes. Scale rows one to eight freckled blackish-brown, the dark pigment concentrated near the anterior margin of scales. Scale rows nine to ten with only scattered flecks. . Subcaudals flecked blackish-brown. Most specimens with a dark loreal streak.

\section{Distribution}

White coastal and near-coastal sands of the upper west coast from Gnaraloo, south to Cape Cuvier (Figure 8).

\section{Material examined}

$1 \mathrm{~km} \mathrm{~S}$ Gnaraloo (81199) [Holotype], Gnaraloo (116652*, 116653-4), Cape Cuvier [site C3 Carnarvon Basin Survey] (125281, 125650).

\section{Remarks}

The holotype is a female with 70 paravertebrals.

\section{Lerista jacksoni sp. nov.}

Figure 11

\section{Holotype}

Western Australian Museum R132644*, a female (SVL $34 \mathrm{~mm}, \mathrm{TL} 44 \mathrm{~mm}$ ) collected on the Burrup Peninsula at $20^{\circ} 31^{\prime} 40^{\prime \prime} \mathrm{S}, 116^{\circ} 49^{\prime} 11^{\prime \prime} \mathrm{E}$ by B. Maryan on 30 May 1998.

\section{Paratypes}

De Grey River Stn (132552), Port Hedland (145601-2), 69km S Pt Hedland (145528), 98km S Pt Hedland (145574), Withnell Bay (61589), Burrup Peninsula $\left(84281,132575,132608-10^{*}, 132645-6^{*}\right.$, 132653-4, 132660, 146579), Whim Creek (114542, 114543*, 114544), Meentheena (139379-80, 139392, 139403), Woodstock (90639, 90914-5, 90924, 993889, 99926, 104083* 104134*, 104953-4), Abydos Stn (145689-90), $2 \mathrm{~km} \mathrm{~W}$ Wittenoom (114318), $20 \mathrm{~km} \mathrm{~W}$ Edginbah (114433*), Carawine Gorge (94680), Mulyie HS (58961), 10km S Shay Gap $\left(114904^{*}\right)$, Doolena Gorge $\left(117283^{*}\right)$.

\section{Diagnosis}

Distinguished from members of the $L$. muelleri species group in Western Australia with fused frontoparietals ( $L$. allochira, $L$. amicorum and $L$. rhodonoides) by having paired frontoparietals. Distinguished from other Western Australian members of the species group with paired frontoparietals and four supraciliaries as follows: from $L$. muelleri (1+2 supraciliaries); from $L$. micra by its reduced (usually darker) dosal pattern which is dusky grey, the dorsolateral stripe is absent and upper lateral stripe reduced to spots (in L. micra the back is grey, olive or brown, the dorsolateral stripe weak or absent and the upper lateral stripe weak but present); from $L$. haroldi by the presence of dark pigment on back and flanks (back and flanks pinkish-grey in $L$. haroldi); and from $L$. nevinae by the absence of a pair of continuous dark paravertebral stripes. The remaining species with paired frontoparietals ( $L$. clara, $L$. kingi, $L$. occulta, $L$. rolfei and L.vehmens) are distinguished from $L$. jacksoni by having five supraciliaries.

\section{Description}

SVL $17-43 \mathrm{~mm}$ ( $\mathrm{N} 46$, mean 31.7 ). TL 33-52 mm (N 13, mean 40.0). TL\%SVL 103.0-162.5 (N 13, mean 125.5). FL 2-4 mm (N 45, mean 3.4). FL\%SVL 7.117.6 ( $\mathrm{N} \mathrm{45}$, mean 10.8). HL 4.5-8.0 mm ( $\mathrm{N} 44$, mean 6.0). HL\%SVL 14.1-26.7 ( N 44, mean 19.0). Lamellae under middle finger 5-11 ( $\mathrm{N} 35$, mean 7.8), lamellae under longest toe 11-19 (N 39, mean 14.8), lamellae under shortest toe 3-5 (N 38, mean 4.3).

Nasals just touching, in moderate or moderately long contact (mean of index 3.2). Prefrontals widely separated. Frontoparietals and interparietal free. Frontoparietals paired. Supraoculars three. 


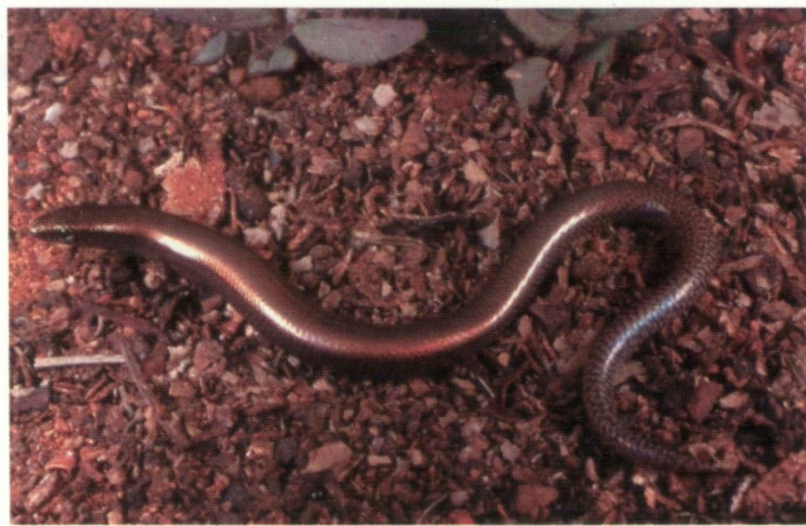

Figure 11 A Lerista jacksoni sp. nov. from Burrup Peninsula. Photograph B. Maryan.

Supraciliaries four, the second and fourth the smallest. Loreals two, anterior the larger. Presuboculars two. Upper labials six. Nuchals two to six (N 44, mean 4.3). Paravertebrals 69-89 (N 39, mean 79.2). Midbody scale rows 20.

Scale rows one and two dusky-grey, the lineopunctate spots weak or absent. Scale row three dusky-grey, pale dorsolateral stripe absent. Upper lateral stripe on scale row four, weak, reduced to a series of spots and usually indistinguishable from the series of spots on the dusky-brown scales of scale rows five to eight, sometimes ten. One specimen with moderately strong lineopunctate spots on scale rows one, two and laterally on three gives the impression of a dusky grey-brown lizard with a series of lineopunctate spots on each row of scales.

\section{Distribution}

The Pilbara plateau and adjacent coast, to the north of the superficially similar $L$. muelleri (Figure 12).

\section{Etymology}

After Gregory Jackson of the Western Australian Museum who has been responsible for the design and layout of many Western Australian Museum publications since 1976 .

\section{Lerista kingi sp. nov.} Figure 13

\section{Holotype}

Western Australian Museum R144164*, a female (SVL $41 \mathrm{~mm}$, tail missing) collected at Mt Gibson, Western Australia in $29^{\circ} 35^{\prime} 47^{\prime \prime} \mathrm{S}, 117^{\circ} 12^{\prime} 45^{\prime \prime} \mathrm{E}$ by R.P. Hart and S. Reynolds on 9 October 2000.

\section{Paratypes}

Mt Gibson (144165*), Wilroy Reserve (57645-7, 57662-3, 57710, 130391), Coalseam Park, near
Mingenew (130193), 22km NE Mingenew (31395), Gutha (141886), Strawberry (141849), Pintharuka Nature Reserve (130564, 134835, 142265), 20km SE Kadji Kadji HS (130589, 142302), Weelhamby Lake (130577, 134848, 134870-1, 134909), $18 \mathrm{~km} \mathrm{~W}$ Morowa (29718), 5km NE Koolanooka (130558), West Pereufori Nature Reserve (130588, 130601, 134823, 137197), Caron (22992, 23916), 11km NE Latham (130546, 134798), Buntine Nature Reserve (44906-8, 44918-9, 44923, 130528, 130540, 134794, $134809,134825,134852,134855,134883,141957$, 142005, 142028-31), 6km E Buntine (60036, 60040), 20km NE Dalwallinu (50152, 58148, 58203,), East Nugadong Nature Reserve (141958), 32km NNW Bonnie Rock (136558), Mollerin (88067), Wialki (18530), Lake Mollerin South (130852, 136500, 136535, 136546, 136552, 142966, 142983), 16km SSW Mt Jackson (67040, 144757), Bungalbin Hill area $\left(144713^{*}, 144733\right), 12.5 \mathrm{~km}$ WSW Black Flag (73243), 6km S Balidu (29888), $3.5 \mathrm{~km} \mathrm{~S}$ Walyahmoning Rock (95937), 6km WSW Walyahmoning Rock (41569), 31km NNW Coolgardie (103909-10), Bulong (123939), 5km W Cadoux (130857-8, 136577, 142360-2), Bencubbin (19998), Dowerin-Cadoux Road (141498*, 141499), Moonijn Nature Reserve (136561, 136576), Waddouring (47772), Warachuppin (133287-92, 134207, 134034, 134128, 134130, 134153 134199-204, 134210, 143880), Mt Moore (133318, 133320, $134058,134162,134172-3), 10 \mathrm{~km}$ SSE Mt Moore (130963, 134008, 134017-8, 134020, 134174, 137128), Billyacatting Nature Reserve (46144, 46148-9, 46369-72, 44408, 46320, 46375), $8 \mathrm{~km} \mathrm{E}$ Kunnunoppin (22344), Weowani Rock (82983), Kwelkan (141736-8, 141744), Burracoppin (134088, 134159, 134186, 134191-7), 6km E Merredin (127615), Lake Campion Nature Reserve (130955-6, 134023, 134025-6, 134028, 134184-5, 140867-8, 142609-10), Yelbeni (140877), 2km SE Boorabbin (74404), 11km E Westonia (28922), Elastigia Nature Reserve (140875), 29km N Kellerberrin (52298, 52301), 35km NNE Kellerberrin (134135, 134215, 134461, 150034-6), Wyalcatchem Nature Reserve (141747), 32km S Trayning (53731), 25km N Kellerberrin (56634-5, 56637-41), Durracoppin Nature Reserve $(134040,134050,134125,134144$, 134216-20, 134223-4, 134226, 134989, 143529, 143869-71), 22km N Kellerberrin (56517, 56521, 56529-30), Kodj Kodjin (95948, 134049, 134137, 134244-5, 134248-9, 134252-5, 134488-9, 137164, 137173, 143876, 150020-2), 17km NW Kellerberrin (52374-7), $3 \mathrm{~km} \mathrm{~N}$ Woolundra (97472-3), Doodlakine $(146693,146696), 20 \mathrm{~km}$ SE Doodlakine (134077, 134145, 134260-1, 134263-9), Marvel Loch (41761), 16km E Toomey Hills (78769, 78801, 117386*), Mount Hampton Nature Reserve (133329), 15km N Eujinyn (134005, 134158-9, 134257-8, 134470-1), 12km NW Clear Streak Well (59887). 


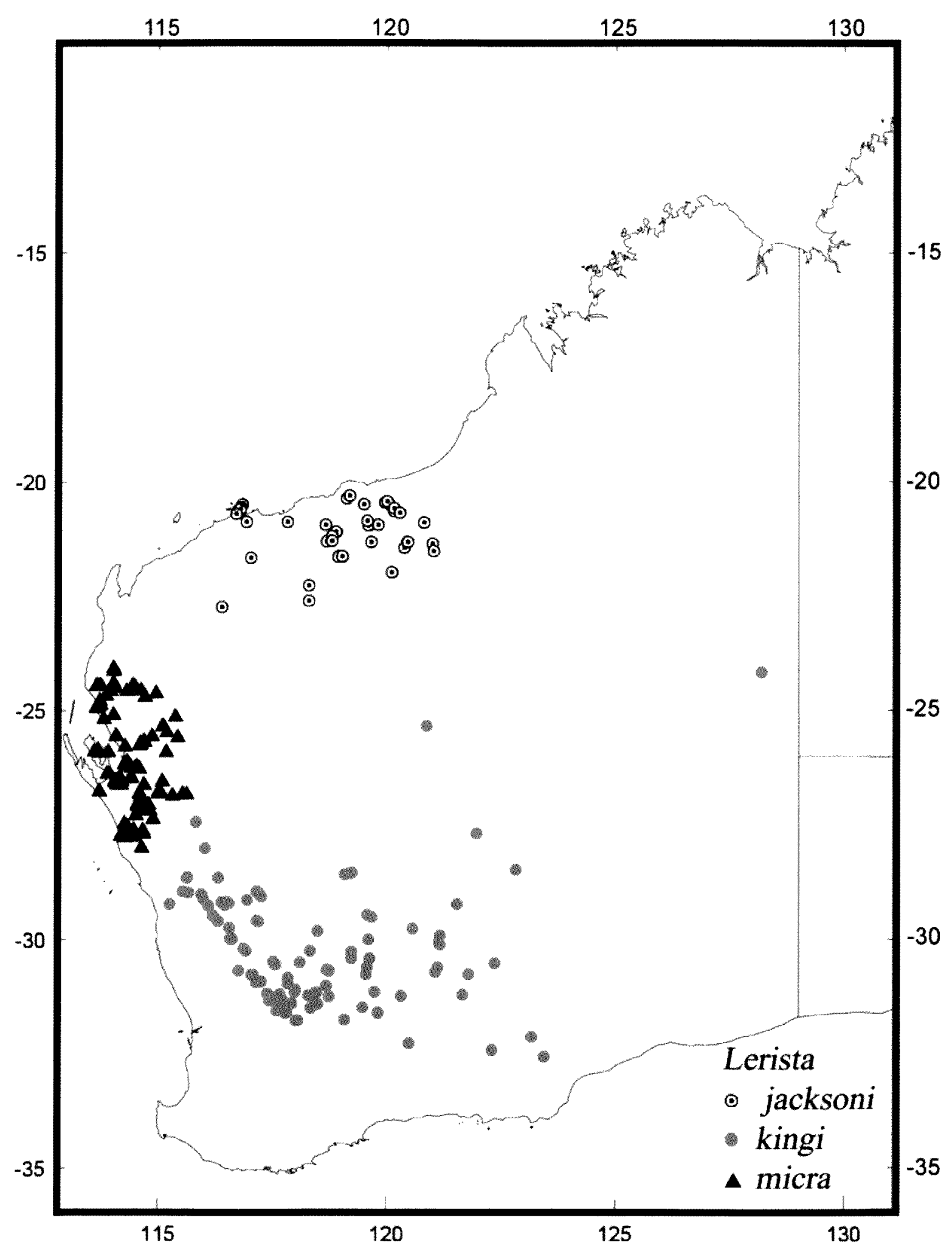

Figure 12 Distribution of Lerista jacksoni sp. nov., L. kingi sp. nov. and L. micra sp. nov. 


\section{Diagnosis}

Distinguished from members of the L. muelleri species group in Western Australia with fused frontoparietals ( $L$. allochira, $L$. amicorum and $L$. rhodonoides) by having paired frontoparietals. Distinguished from L. haroldi, L. jacksoni, L. micra, $L$. muelleri and $L$. nevinae by having five supraciliaries (four in L. haroldi, L. jacksoni, L. micra, L. nevinae and $1+2$ in L. muelleri). Distinguished from those species which also have five supraciliaries as follows: from $L$. clara by having a pigmented venter (immaculate pearlywhite in L. clara); from L.verhmens by its smaller size (mean SVL of $L$. kingi up to $37.3 \mathrm{~mm}$ versus $40.5 \mathrm{~mm}$ in $L$. verhmens); from $L$. rolfei by lacking a hiatus immediately below the upper lateral stripe (hiatus present in L. rolfei); and from L. occulta by its its dorsal colour (usually brown in L. kingi versus purplish in L. occulta).

\section{Description}

SVL 18-46 mm (N 151, mean 37.3). TL 22-52 mm (N 32, mean 41.9). TL\%SVL 105.1-131.6\% (N 32 , mean 116.0). FL 2.5-5.0 mm (N 143, mean 3.4). FL\%SVL 6.6-16.7 (N 143, mean 9.1). HL 6.0-10.0 mm (N 143, mean 8.4) HL\%SVL 15.1-33.3 (N 143, mean 22.5). Lamellae under middle finger 5-9 ( $\mathrm{N}$ 80, mean 6.6), under longest toe 10-18 (N 82, mean 14.0), under shortest toe 3-6 ( $\mathrm{N} \mathrm{83,} \mathrm{mean}$ 4.0).

Nasals just touching, in moderate or moderately long contact (mean of index 2.6). Prefrontals widely separated. Frontoparietals and interparietal free. Supraoculars three. Supraciliaries five, the second and fourth the smallest. Loreals two, anterior the larger. Presuboculars two. Upper labials six. Nuchals three to nine ( $\mathrm{N} 148$, mean 6.0). Paravertebrals 65-88 (N 126, mean 75.9). Midbody scale rows 20.

Scale rows one and two brown, olive or grey (usually brown). Lineopunctate spots on scale rows one and two almost always present, often in the form of strong oblong streaks which sometimes coalesce into a stripe but also in the form of spots and dots more commonly found in other species in the complex. Pale dorsolateral stripe on scale row

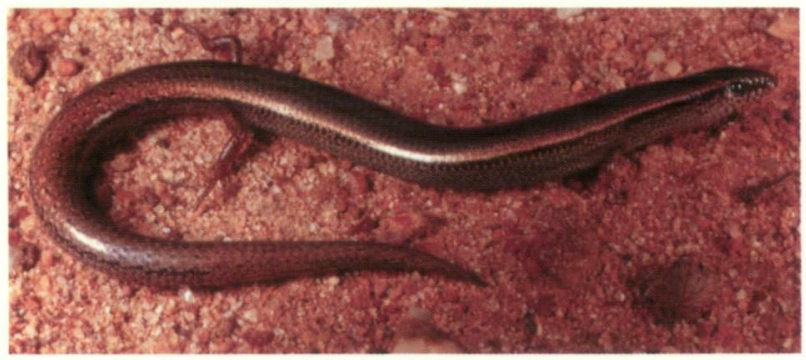

Figure 13 A Lerista kingi sp. nov. from $5 \mathrm{~km}$ south of Trayning. Photograph B. Maryan. three weak to moderately strong. Upper lateral stripe commences on lateral margin of dorsal row three and extends as far as $60 \%$ down the dorsal part of scale row four. Blackish-brown pigment of upper lateral stripe almost always continuous dorsally but restricted to sutures ventrally creating a particoloured or deeply scalloped stripe. Forward of the axilla the upper lateral stripe is usually solid and continues through the temporals and lores to the rostral. Scale rows five to ten pale, usually with a dark spot on each scale which collectively create irregularly arranged rows. In poorly pigmented specimens the upper lateral stripe can extend as little as $20 \%$ down scale row four and have little scalloping creating a narrow solid upper lateral stripe. This is usually associated with more weakly pigmented flanks (diffuse flecks rather than spots). Head shields with dark blotches. Upper surfaces of limbs brown, olive or grey, freckled with darker pigment.

\section{Distribution}

Widely distributed in southwest Western Australia including many nature reserves in the wheatbelt (Figure 12).

\section{Remarks}

The dorsal and lateral patterns of $L$. rhodonoides and $L$. kingi are indistinguishable. It is the more densely pigmented ventral scales of $L$. kingi that, in most cases, distinguishes it from $L$. rhodonoides.

Not included in the description are certain specimens from widely scattered localities to the northeast of the distribution of $L$. kingi (the western Great Victoria Desert and the Eastern Goldfields province of the Yilgarn Block). Although no obvious differences can be found between this series of specimens and other $L$. kingi, the upper lateral stripe of these inland specimens appears to be a little more sharply defined. This and the anomalous distribution of the two could be an indication that there is yet, another undescribed species in the complex. The 26 specimens are: 50074-6 (Billabalong HS), 51186 (Billabalong Stn), 64815 (Blue Hill, Lake Barlee), 66026 (35 km WNW Bajawarn HS), 67040 (16 km SSW Mt Jackson), 67472 (Riverina HS), 69034 (7.5 km E Yuinmery HS), 75671 (1 km N Yuin), 78629 (16 km SSE Mt Elvire HS, 84141-4 (14 km NNE Warriedar), 96627 (Lochada Stn), 117310-1, 117321-3 (4 km SSE Thundelarra), 141157 (39 km E Point Salvation), 145351 (Carnarvon Range).

\section{Etymology}

After Dennis King (1942-2002), contributor and Honourary Associate of the Herpetology Department of the Western Australian Museum for many years. 
Lerista micra sp.nov.

Figure 14

\section{Holotype}

Western Australian Musem R116786*, a male, SVL $31 \mathrm{~mm}$, TL $42 \mathrm{~mm}$. Collected $4 \mathrm{~km}$ south of Gilroyd HS Western Australia at $25^{\circ} 51^{\prime} \mathrm{S}, 115^{\circ} 11^{\prime} \mathrm{E}$ on 22 June 1993 by G. Harold and B. Maryan.

\section{Paratypes}

Gnaraloo (76857, 76859-60), 10km W Manberry HS (76843), 33km S Minilya HS (103296-7), Booloogooro (127892, 127894, 127897-8), Mardathuna (120618, 120636-7, 120681, 120965, 120983, 121002, 121007, 121030, 121042-3, 121074, 121250-1, 121521-5, 121528, 121535-7, 121540, $121542-3,122121,122124-5,122293,122308,122715$, $122831-3,122870,122876^{*}, 122896^{*}, 123367,123373$, $123435,123462,124951,124957,125346,125348-53$, 125359-61, 125418-21, 125443-45, 125448-50, 1257112, 125802-3, 125831, 126218, 126221, 126329), Boolathana Stn $(120577,120579,120581,120584$, $120588,120590,120592-3,120639,120645^{*}, 120648$, 121672-6, 121694-702, 121708-13, 121715-24, 121729, $121733,122056-7,122066,122068,122128-9,123416$, $123420,123436,123994-5,125203,126318-20$, 126323-6, 126559, 126603-4, 126606, 126611, 126613), $13 \mathrm{~km}$ SW Cooralya HS (116551-3*), $8 \mathrm{~km} \mathrm{~W}$ Cooralya HS (76590), 30km SSE Cooralya HS (89626), Kennedy Range, 15km WNW Binthalya HS (71545), 25km N Carnarvon (36087-9), 12km NE Carnarvon (71499-500), Bush Bay (120424, 120446, $120448,121282,122150,122153,125682,126146$, 126153), Windarrie HS (87540-1), $21 \mathrm{~km}$ SW Edagee HS (89745), 10km NNW Carey Downs HS (114339), Meedo Stn (121582, 121592, 121608-9, 122535-7, $122547,122574,122599-604,122619-21,122652$, $122654-5,122657,122659,122677-81,122686$, $122695,122700,122706-7), 11 \mathrm{~km} \mathrm{NE}$ Carbla HS (141613), Carbla HS (116575-7*, 116582-5*), Peron Peninsula (120829, 121660-2, 121671, 122282-3, 123609-10), $14 \mathrm{~km} S$ Yaringa HS (89710-15), Woodleigh Stn $(57379-83,120902 *, 121326,122098$, $122104,122977,122994,122998-9,123005,123015$, $123029,123034,123038,123057,123087,124926-7$, 124953, 125435, 125798, 125810-11), 13km S Nanga HS (54970, 55192), $17 \mathrm{~km} \mathrm{~S} \mathrm{Nanga} \mathrm{HS} \mathrm{(55207),} 7 \mathrm{~km}$ S Nilemah (93908-9, 93912), 9km S Nilemah HS (92435, 92454), 17km S Nilemah HS (92841, 92853, 92859), Hamelin Pool (54603-4), Overlander Roadhouse (116747-8*), 6km W Overlander Roadhouse (88774), Dubaut Creek (119141),19km E Hamelin Pool (29678), 7km S Hamelin HS (89943), $13 \mathrm{~km}$ SW Hamelin HS (88937, 89648, 92272, 92274, 92282, 92285, 92336-7, 92339, 92658, 93979), $13.5 \mathrm{~km}$ S Hamelin HS (92231), 10 km SW Hamelin HS (87907), 11km SW Hamelin HS (89890-3, 92296, 92626), 11km SSW Hamelin HS (92296-7, 92308), $11 \mathrm{~km}$ S Hamelin HS (89635), 12km SW Hamelin HS
(89814-5, 92324-5, 92467, 92484-5, 92492, 92777, 92780, 93955, 93960), 14 km SW Hamelin HS (92687, 92898-9, 92914, 92921, 92943, 92949), 14 km WSW Hamelin HS (89671-3), 15km S Hamelin HS (92553, 92561, 92576, 93939, 93943), 15km SW Hamelin HS (92349-50, 92352-3, 92363, 92367, 92370-71, 92376), $16 \mathrm{~km}$ S Hamelin HS (89845), 18km SSW Hamelin HS (92399, 92404, 92517, 92816), 20km SW Hamelin HS (89574), 1km S Tamala HS (54509-519, 56473, $64554), 37 \mathrm{~km}$ E Meadow HS (60644), 6km NNW Wannoo (71142), Wannoo (71063, 71126), 14km SSE Wannoo (85168-72). 22km N Nerren Nerren HS (64305), Nerren Nerren Stn (120777-8, 120878, 120885, 120900, 120907, 120928, 120931, 120950-1, 121312, 121339, 122361-3, 122365-6, 122374, 122934, $122957,122979,124922,124976,125502,125606$, $125609,126239), 17 \mathrm{~km}$ SW Nerren Nerren HS (64321-3), 38km SE Nerren Nerren HS (59630), 4km SE Carrollgouda Well (116875-6*), The Loop, Kalbarri National Park (29621-2, 29629, 29633-4), Junga Dam, Kalbarri National Park (86880, 95522), Kalbarri National Park (37636), 30km E Kalbarri (33585), Z Bend, Kalbarri National Park (131740), Eurardy Stn $\left(115233^{*}\right), 24 \mathrm{~km} \mathrm{~N}$ Galena (71112), 20.5km NNE Murchison House HS (116701*).

Island locality: Faure I. (141692).

\section{Diagnosis}

Distinguished from members of the L. muelleri species group in Western Australia with fused frontoparietals (L. allochira, L. amicorum and $L$. rhodonoides) by having paired frontoparietals. Distinguished from members of the species group which also have paired frontoparietals and fewer than five supraciliaries (L. haroldi, L. jacksoni, $L$. muelleri and L. nevinae) as follows: from $L$. haroldi by the presence of an upper lateral stripe (absent in L. haroldi); from L. jacksoni by its paler dorsal colouration and weak upper lateral stripe ( $L$. jacksoni has a very dark back and the upper lateral stripe often absent); from $L$. muelleri having four supraciliaries $(1+2$ in $L$. muelleri); from $L$. nevinae by the absence of a continuous dark paravertebral

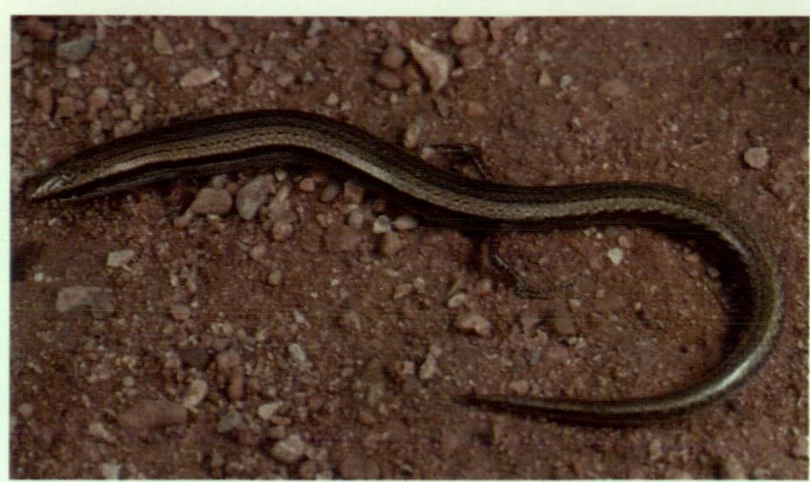

Figure 14 A Lerista micra sp. nov. from $11 \mathrm{~km}$ north east of Carbla Homestead. Photograph G. Harold. 
stripe (present in L. nevinae). Distinguished from $L$. clara, L.kingi, L. occulta, L. rolfei and L. verhmens by having four, rather than five, supraciliaries.

\section{Description}

SVL 17-46 mm (N 418, mean 30.9). TL 23-53 mm (N 113, mean 36.3). TL\%SVL 102.7-146.3 (N 104, mean 121.0). FL 2-9.5 mm (N 338, mean 3.5). FL\%SVL 6.7-31.5 (N 336, mean 11.4). HL 2.5-10.0 $\mathrm{mm}$ ( $\mathrm{N}$ 340, mean 7.7). HL\%SVL 7.1-35.0 (N 338, mean 24.8). Lamellae under middle finger 5-11 (N 147, mean 7.2), lamellae under longest toe 10-19 (N 147 , mean 14.3), lamellae under shortest toe 3-6 (N 144, mean 4.1).

Nasals just touching, in moderate or moderately long contact (mean of index 3.2). Prefrontals widely separated. Frontoparietals and interparietal free. Frontoparietals paired. Supraoculars three. Supraciliaries four, the second and fourth the smallest. Loreals two, anterior the larger. Presuboculars two. Upper labials six. Nuchals none to eight (N 336, mean 4.8). Paravertebrals 57-92 (N 268, mean 67.5). Midbody scale rows 20.

Scale rows one and two grey, olive or brown (mostly brown). Row one with a series of weak to strong lineopunctate spots; row two with or without weak to strong lineopunctate spots. Medial margin of scale row three, grey, olive or brown (mostly brown), pale dorsolateral stripe weak or absent, ventral margin of dorsal row three blackishbrown (proximal margin of upper lateral stripe). Usually all (but as little as 30\%) of scale row four, particoloured (pigment centered around scale sutures) giving upper lateral stripe a sculptured appearance. Scale rows five to eight dusky greyishbrown with irregular spots and flecks.

\section{Distribution}

Upper west coast and hinterland from Gnaraloo in the north, south to the Murchison River and inland to Carey Downs and Nerren Nerren Stations (Figure 12).

\section{Etymology}

The specific epithet micra is derived from the Greek mikros (small). Lerista micra is one of the smallest species discovered so far in the L. muelleri species group.

\section{Lerista muelleri (Fischer 1881) Figure 15}

Phaneropis (Lerista) muelleri Fischer J.G., 1881. Beschriebung neuer Reptilien. Archiv für Naturgeschte 47: 225-238 [236].

Fischer (1881) based his description of Phaneropis (Lerista) muelleri on two specimens in the Staatliches Museum fur Naturkunde in Stuttgart
(SMNS 2057a-b) from Nichol Bay, Western Australia, obtained by F. von Mueller. The zoological collections at the Stuttgart Museum were damaged during the war between 1939-1945 and the syntypes of $P$. muelleri were among the 12 types considered lost (Schluter and Hallerman 1997). Earlier, Cogger et al. (1983) had reached the same conclusion.

In the mid-to late nineteenth century the Institut für Systematische Zoologie (formerly Zoologische Museum Berlin of the Museum fü Naturkunde der Humbold-Universität zu Berlin) received types and putative types from a number of European museums including the Staatliches Museum fur Naturkunde in Stuttgart. Among the specimens that found their way to Berlin was a short series of specimens (ZMB 10062-74) obtained directly from van Krass at the Stuttgart Museum (Bauer et al., 2003). In the absence of the two types of Phaneropsis muelleri at Stuttgart and the uncertainty of their fate, Bauer et al. (2003) consider ZMB 10074 (rediscovered by G. Shea during a visit in 1992) a specimen of questionable status as a type. The following description of ZMB 10074 is based in notes and a sketch made by G. Shea.

\section{Description of ZMB10074}

SVL $39 \mathrm{~mm}$. FL $4 \mathrm{~mm}$. HL $7.5 \mathrm{~mm}$. Ablepharine eye. Ear aperture small. Three fingers, three toes. Midbody scales 20. Upper labials six. Nasals in broad contact. Prefrontals broadly separated. Three supraoculars, first two in contact with frontal. First supraciliary narrowly separated from frontal. Second supraciliary fused to first supraocular. Last supraciliary smallest. Two squarish loreals of equal size. Interparietal free. Frontoparietals paired. Paravertebrals 78 (counted from parietal to last scale anterior to anterior edge of hind limbs). Subdigital lamellae (longest toe) 13.

Specimen entirely bleached but definitely no trace of upper lateral stripe (Fischer describes the belly and the underside of the tail dark brown).

There is only one species within the L. muelleri species group from the Nichol Bay area that agrees with Shea's description of ZMB10074 and that is Fischer's descriptions of Phaneropis muelleri based on SNMS 2057a-b. In particular both describe the second supraciliary being fused to the first supraocular as shown in Figure 2c (this paper) and Fischer (1881, Figure 13). Shea's SVL measurement of ZMB10074 is only $1 \mathrm{~mm}$ less than that given by Fischer for syntype 2057a (total length "0.085m, tail $\left.0.045 \mathrm{~m}^{\prime \prime}\right)$, but very different to the measurements for syntype $2057 \mathrm{~b}$ (total length "0.06m, tail $0.03 \mathrm{~m}$ ").

We consider ZMB 10074 to be SNMS 2057a and, by default, the lectotype of Phaneropis muelleri. Bauer and colleagues' concerns about the type status of ZMB10074 were probably unfounded considering how few reptiles were collected from 


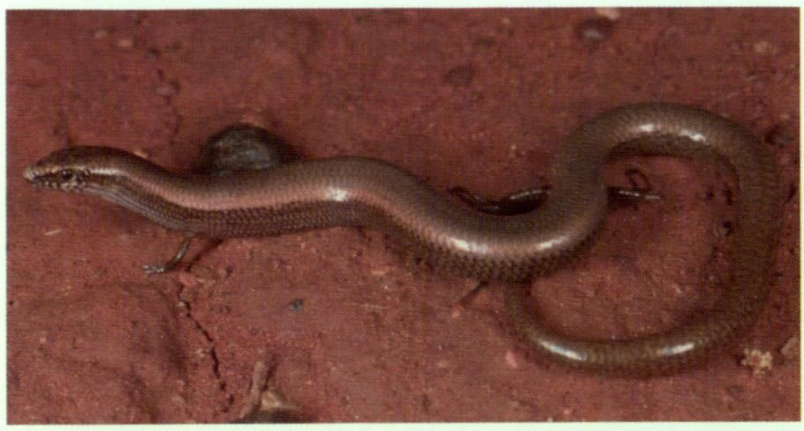

Figure 15 A Lerista muelleri from Cherralta Homestead. Photograph G. Harold.

northwest Australia in the second half of the nineteenth century (especially cryptic forms such as species of Lerista), the documented transfer of specimens from Stuttgart to Berlin and the concordance of the descriptions and measurements.

\section{Redescription of Lerista muelleri (Fischer 1881)}

\section{Diagnosis}

Distinguished from all other members of the $L$. muelleri group by having the second supraciliary fused with the first supraocular.

\section{Description}

SVL 20-41 mm (N 89, mean 34.2). TL 31-54 mm (N 18, mean 44.2). TL\%SVL 106.9-142.1 (N 18, mean 122.3). FL 2.5-4.5 mm (N 59, mean 3.4). FL\%SVL 6.6-13.6 (N 59, mean 9.9). HL 5-8.5 mm (N 59, mean 6.2). HL\%SVL 12.8-25.0 (N 59, mean 18.1). Lamellae under middle finger 5-12 ( $\mathrm{N} \mathrm{49}$, mean 7.6), under longest toe 12-20 ( $\mathrm{N} \mathrm{47,} \mathrm{mean} \mathrm{15.4),} \mathrm{under} \mathrm{shortest}$ toe 3-5 ( $\mathrm{N} 48$, mean 4.2).

Nasals just touching, in moderate or moderately long contact (mean of index 3.0). Prefrontals widely separated. Frontoparietals and interparietal free. Supraoculars three, the first fused with the second supracilliary. Supraciliaries three, the second fused with the first supraocular, the third the smallest. Loreals two, anterior the larger. Presuboculars two. Upper labials six. Nuchals two to eight (N 62, mean 5.2). Paravertebrals 72-94 (N 77, mean 81.5). Midbody scale rows 20 .

Top of head flecked with blackish-brown. Blackish-brown loreotemporal streak extends forward through the nasal and across the lip of the rostral. Back brown or olive. Scale rows one and two usually without lineopunctate dorsal stripes, sometimes on scale rows one and two, rarely on scale row one only. Pale dorsolateral stripe absent. Upper margin of lateral stripe not solid, reasonably well defined (commences on lateral margin of scale row three), the lower margin of lateral stripe ill-defined (darker pigment progressively less prominent through scale rows five to eight). This broad, diffuse stripe is discontinuous (reduced to a blotch on the anterior portion of each scale). Belly with scattered brownish spots. Sides of tail with dark flecks. Subcaudals with dark flecks.

\section{Material examined}

Port Hedland area (146606), Cape Preston (141298*, 141357*), Abydos Stn (146358-9), Mt Brockman (135384, 135457-8), 3km NE Mt Brockman (119912, 119916), Asbestos Gorge, Hamersley Range National Park (20072, 20075), Marandoo, Hamersley Range National Park (52706), Hamersley Range National Park (138184-6, 138228-30, 138256), 2km W Wittenoom (114309, 114311), Millstream National Park (88835, 88839, 88977), Hamersley Stn (131742,131745), Tambrey (SAM 4477-8, SAM 4480, SAM 4482, 20071, 20074, 151297), 22km S Roebourne (73853), Myaree Pool (61567), 10km SSW Cooya Pooya HS (76439), Tom Price (127790, 127801 127808, 127813, 145249), 5km S Tom Price (127715), Hope Downs (117339, 117271-2, 117275, 135277), West Angelas (138954, 138959, 138961, 138967, 138976), 9km E Mt Maguire (94860), Joyhelen Mine (102005), $34 \mathrm{~km}$ E Nanjilgardy Pool (117142), 10km SW of Pannawonica (68333, 68338), 12km SW Pannawonica (108598, 108611), Robe River (113243), Cherralta HS $\left(108818,108827^{*}, 151300\right)$, Barlee Range (102216-9, 102236-8*, 102241, 102373-4), Kookhabinna Creek, Barlee Range Nature Reserve (102043), 7km ENE Mt Windell (102192), Mt Robinson (131851), 31km SE Mt Meharry (66334), 53km WNW Newman (1145734), between Nullagine and Roy Hill (68368), 30km ENE Newman (125495), 15km ENE Newman (125091), Capricorn Range (78969), 5km S Prairie Downs HS $\left(114325^{*}\right)$.

\section{Distribution}

The Pilbara plateau and nearby rocky outliers (Figure 16).

\section{Lerista nevinae sp. nov.}

Figure 17

\section{Holotype}

Western Australian Museum 135295*, SVL 37 $\mathrm{mm}$, TL $46 \mathrm{~mm}$ an adult male collected by R. Teale near Cape Lambert, Western Australia at 20³6'45.6"S, 117²10'39.1"E.

\section{Paratypes}

$135306^{*}, 151303$ (Cape Lambert).

\section{Diagnosis}

The only species in the L. muelleri species group with a continuous black paravertebral stripe and 18 midbody scale rows. 


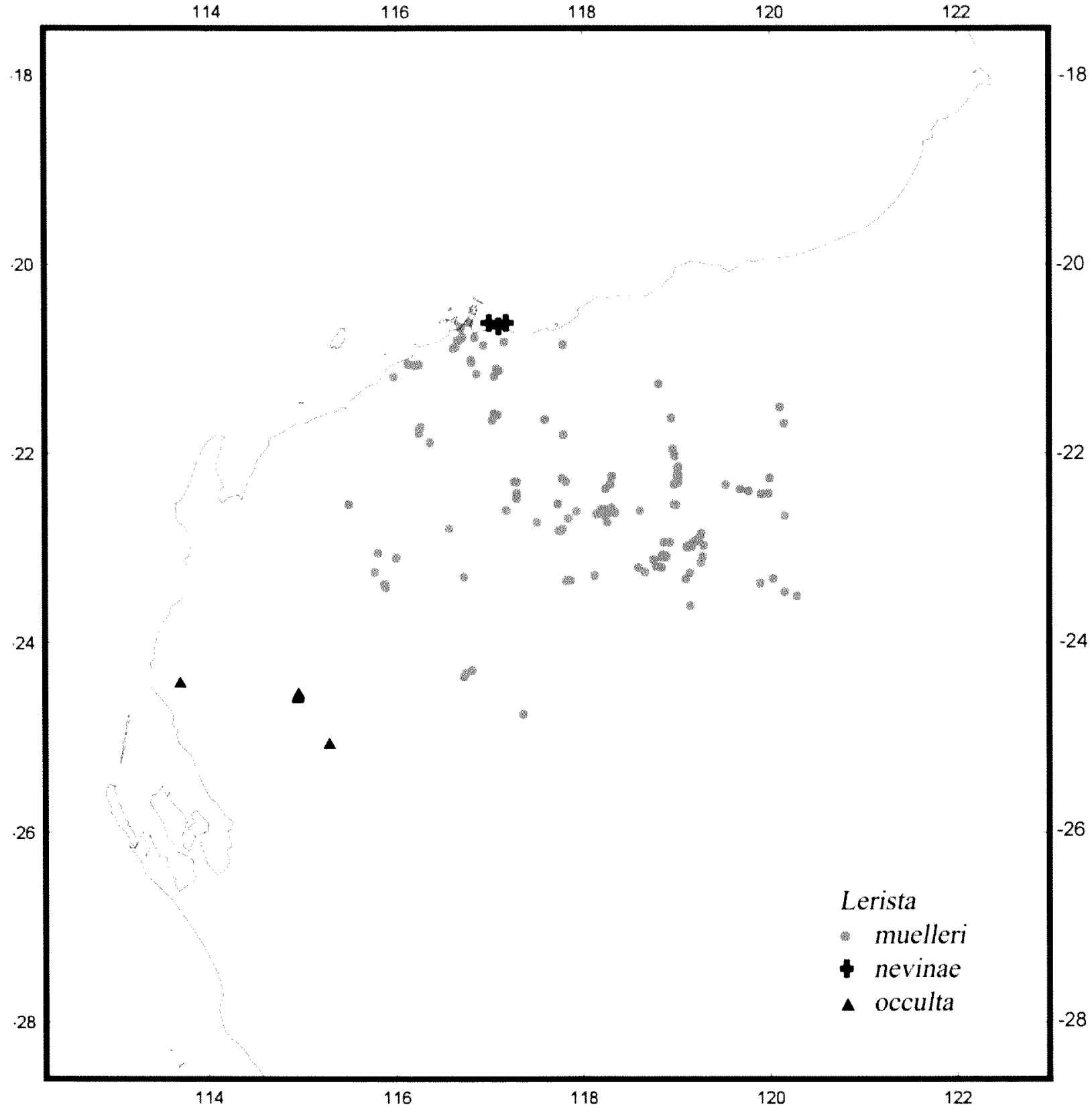

Figure 16 Distribution of Lerista muelleri, L. nevinae sp. nov. and L. occulta sp. nov.

\section{Description}

SVL 34-41 mm (N 3, mean 37.3). TL 42-46 mm (N 2, mean 44.0). TL\%SVL 123.5-124.3 (N 2, mean 123.9). FL 5.0-5.5 mm ( $\mathrm{N} 3$, mean 5.2). FL\%SVL 13.4-14.7 (N 3, mean 13.9). HL 9-11.5 mm ( $\mathrm{N} 3$, mean 10.0). HL\%SVL 21.9-33.8 ( $\mathrm{N} 3$, mean 27.1). Lamellae under middle finger 7-8 (N 3, mean 7.6), under longest toe 15-16 ( $\mathrm{N} 3$, mean 15.7), under shortest toe four (all specimens).

Nasals in long contact (mean of index 3.7). Prefrontals widely separated. Frontoparietals paired. Interparietal free. Supraoculars three, the first two in contact with the frontal. Supraciliaries four, the third the largest, fourth minute (fused to third on one side of 135295). Two loreals, the posterior scale about one quarter the size of the anterior (it is about half the length and about half the height). Presuboculars two. Upper labials six. Nuchals two to four (N 3, mean 2.7) Paravertebrals 68-70 (N 3, mean 69.0). Midbody scale rows 18.

Top of head heavily pigmented with blackishbrown, the pigment tending to form two ragged 


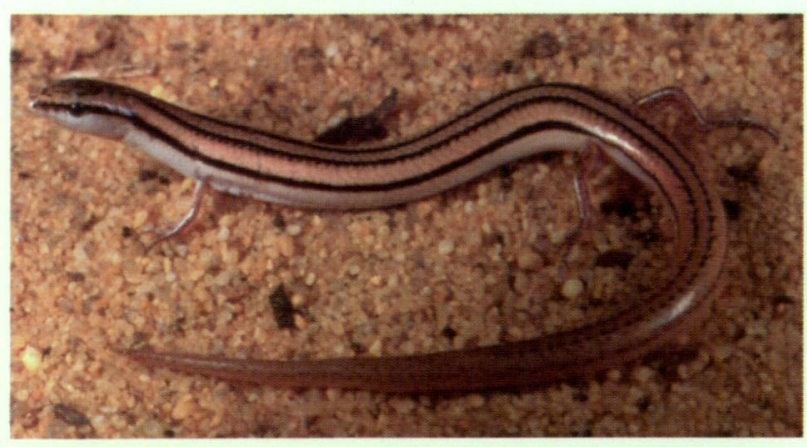

Figure 17 A Lerista nevinae sp. nov. from Cape Lambert. Photograph by B. Maryan.

lines forward to the frontoparietals (these marks are fragmenting forward extensions of paravertebral stripes). Back almost white with a solid, slightly ragged-edged paravertebral stripe straddling two scales (lateral half to one third of scale row one and medial third to one quarter of scale row two). Pale dorsolateral stripe absent. Upper lateral stripe solid, sharply defined, straddling two scales (lateral third of scale row three and medial half of scale row four). Lower flanks and belly (scale rows five to nine) immaculate white. Tail yellowish. Upper surfaces of limbs spotted and streaked dark brown.

\section{Distribution}

Known only from the type locality between Point Samson and Cape Lambert (Figure 16).

\section{Remarks}

The original specimens (135295 and 135306) were collected over two days on a coastal dune vegetated with Acacia coriacea and low shrubs. Snout-vent length of single adult male $37 \mathrm{~mm}$; SVL of single adult female $40 \mathrm{~mm}$.

\section{Etymology}

Named for Anne Nevin of the Western Australian Museum from 1982-2006. Natural Sciences Departmental Secretary from 1985 and resuscitator of countless rubricated manuscripts.

\section{Lerista occulta sp. nov.}

\section{Holotype}

Western Australian Museum R120526*, an adult male, SVL $34 \mathrm{~mm}$, tail $28 \mathrm{~mm}$. Collected from the slopes of the western face of the Kennedy Range at $24^{\circ} 33^{\prime} 04.6^{\prime \prime} \mathrm{S}, 114^{\circ} 57^{\prime} 31.5^{\prime \prime} \mathrm{E}$ [site KE4, Carnarvon Basin Survey] collected by A. Desmond on 10 August 1994.

\section{Paratypes}

Kennedy Range (Site KE3 Carnarvon Basin
Survey) (122047-9, 123249), Kennedy Range (Site KE4 Carnarvon Basin Survey) (121331-2, 122051, 123265, 123290, 123293, 123296*, 125189, 125191, 125881, 126211), Kennedy Range (Site KE5 Carnarvon Basin Survey) (121298-300, 123269, 123286, 125878-9, 125892-3), Boolathana Stn (125519), Bidgiemia Stn (125518).

\section{Diagnosis}

Distinguished from members of the L. muelleri species group in Western Australia with fused frontoparietals ( $L$. allochira, $L$. amicorum and $L$. rhodonoides) by having paired frontoparietals. Distinguished from L. haroldi, L. jacksoni, L. micra, $L$. muelleri and $L$. nevinae by having more supraciliaries (usually five in $L$. occulta versus four in $L$. haroldi, $L$. jacksoni, $L$. micra, $L$. nevinae and $1+2$ in $L$. muelleri). Distinguished from those species with paired frontoparietals and five supraciliaries as follows: from $L$. clara by having a pigmented venter (opalescent white in $L$. clara); from $L$. kingi by its relatively long forelimbs (mean $13.9 \%$ versus $9.1 \%$ of SVL in $L$. kingi); from $L$. rolfei by the lack of a hiatus below the upper lateral stripe (present in $L$. rolfei); and from $L$. verhmens by its smaller size (mean SVL for $L$. micra $30.9 \mathrm{~mm}$ versus $40.5 \mathrm{~mm}$ for $L$. verhmens). Generally similar to $L$. micra in size and scalation but differs in colour. Lerista occulta is purplish-brown rather than brown or grey and usually has five supraciliaries (usually four in L. micra).

\section{Description}

SVL 17-39 mm (N 27, mean 30.9). TL 32-41 mm (N 3, mean 36.3). TL \% SVL 100-117.4 (N 3, mean 105.7). FL 3-8.5 mm (N 20, mean 4.3), FL\%SVL 8.326.4 (N 20, mean 13.9). HL 3.0-9.0 mm (N 20, mean 7.1). HL\%SVL 17.6-30.8 (N 20, mean 22.3). Lamellae under middle finger 6-9 ( $\mathrm{N} \mathrm{10,} \mathrm{mean} \mathrm{7.0,} \mathrm{under}$ longest toe 11-17 ( $\mathrm{N} 15$, mean 13.8), under shortest toe 3-4 (N 15, mean 3.8).

Nasals just touching, in moderate or moderately long contact (mean of index 3.0). Prefrontals widely separated. Frontoparietals and interparietal free. Supraoculars three. Supraciliaries usually five, the second and fourth the smallest. Loreals two, anterior the larger. Presuboculars two. Upper labials six. Nuchals three to six (N 22, mean 5.1). Paravertebrals 62-76 (N 12, mean 70.6). Midbody scale rows 20.

Scale rows one and two dark purplish-brown each with or without a weak to strong series of lineopunctate spots. Medial margin of scale row three purplish-brown, pale dorsolateral stripe usually absent, occasionally very weak. Ventral margin of scale row three solid blackish-brown or with a series of blackish-brown blotches (proximal margin of upper lateral stripe). Usually all (but as little as $50 \%$ ) of scale row four, particoloured 
(pigment centered around scale sutures) giving scales a sculptured appearance. Scale rows scales five to seven or five to eight, freckled dusky-brown (in dark specimens almost black), the pigment concentrated at the posterior edge of each scale.

\section{Distribution}

Flats along western face of the Kennedy Range. Also vicinity of Gascoyne Junction (Figure 16).

\section{Etymology}

The specific epithet is Latin for hidden, alluding to the fact that the relatively few $L$. occulta remained undetected among several hundred $L$. micra until identified by allozyme electrophoresis of Aplin, Adams and Cowan.

\section{Lerista rhodonoides (Lucas and Frost 1896) Figure 18}

Ablepharus rhodonoides Lucas, A. H., and Frost, C. 1896. Description of a new species of Ablepharus from Victoria, with critical notes on two other Australian lizards. Proceedings of the Linnean Society of NSW 21: 281-283 [281].

Lygosoma (Rhodona) goerlingi Ahl, 1935. Beschreibung einerneuen Eidechse aus Westralien. Zoologischer Anzeiger 112: 204-205 [204].

\section{Diagnosis}

Distinguished from L. clara, L. haroldi, $L$. jacksoni, L. kingi, L. micra, L. muelleri, L. nevinae, $L$. occulta, $L$. rolfei and $L$. verhmens by having fused frontoparietals. Distinguished from $L$. allochira and L. amicorum which also have fused frontoparietals as follows: from $L$. allochira by having three fingers (two in L. allochira) and from L. amicorum by always having 20 midbody scales (22 midbody scales in a third of $L$. amicorum specimens).

\section{Description}

SVL 20-49 mm (N 460, mean 37.7). TL 22-60 mm (N 118, mean 43.3). TL\%SVL 102.3-151.3 (N 102, mean 117.3). FL 2.5-5.5 mm ( $\mathrm{N} \mathrm{340,} \mathrm{mean} \mathrm{3.5).}$ FL\%SVL 5.9-14.3 (N 354, mean 9.4). HL 5.5-12 mm (N 356, mean 8.3). HL\%SVL 14.3-30.0 (N 354, mean 22.1). Lamellae under middle finger 3-12 (N 221, mean 7.1), under longest toe 10-20 (N 226, mean 14.8), under shortest toe 3-6 (N 226, mean 4.3).

Nasals just touching, in moderate or moderately long contact (mean of index 2.7). Prefrontals widely separated. Frontoparietals fused. Interparietal free. Supraoculars three. Supraciliaries five, the second and fourth the smallest. Loreals two, anterior the larger. Presuboculars two. Upper labials six.
Nuchals zero to eight (N 353, mean 6.1. Paravertebrals 63-95 (N 450, mean 77.8). Midbody scale rows 20 .

Scale rows one and two brown, olive or grey (usually brown). Lineopunctate spots on scale rows one and two almost always present, often in the form of strong oblong streaks which sometimes coalesce into a stripe, but also in the form of the spots and dots more common in other species in the complex. Pale dorsolateral stripe on scale row three weak to moderately strong. Upper lateral stripe commences on ventral margin of scale row three and extends as far as $60 \%$ down the dorsal part of scale row four. Blackish-brown pigment almost always continuous dorsally but restricted to sutures ventrally creating a particoloured or deeply scalloped stripe. In poorly pigmented specimens the upper lateral stripe can extend as little as $20 \%$ down scale row four and have little scalloping creating a narrow solid upper lateral stripe. Forward of the axilla the upper lateral stripe is usually solid and continues through the temporals and lores to the rostral. Scale rows five to eight pale, usually with a dark spot on each scale which, collectively, create irregularly arranged rows. More weakly pigmented flanks (diffuse flecks rather than spots) are usually associated with a narrower upper lateral stripe. Head shields with dark blotches. Upper surfaces of limbs brown, olive or grey, freckled with darker pigment.

\section{Distribution}

Widespread and common in the mideast interior of Western Australia (Figure 19). East into South Australia, southern Northern Territory, north-west Victoria and New South Wales and Queensland.

\section{Material examined}

Junction Well (42260, 42262), 3km SE Turee Creek HS (25143-6), 25km SSW Mundiwindi (114907), Little Sandy Desert at $24^{\circ} 03^{\prime}, 120^{\circ} 24^{\prime}$ (136000-4), Little Sandy Desert at $24^{\circ} 05^{\prime}, 120^{\circ} 20^{\prime}$ (136056-7) Little Sandy Desert at $24^{\circ} 35^{\prime}, 120^{\circ} 16^{\prime}$

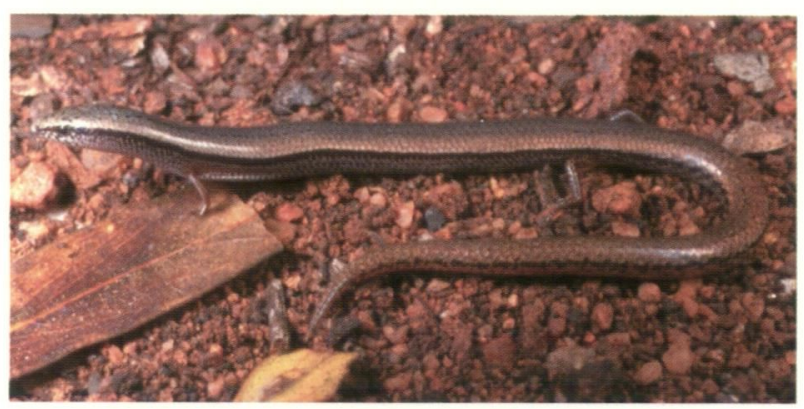

Figure 18 A Lerista rhodonoides from McDermid Rock, Western Australia. Photograph B. Maryan. 
(136058), Little Sandy Desert at $24^{\circ} 30^{\prime}$, $120^{\circ} 18^{\prime}(137534)$, Little Sandy Desert at $24^{\circ} 03^{\prime}$, $120^{\circ} 24^{\prime}(137535-7,137540-2)$, Little Sandy Desert at $24^{\circ} 25^{\prime}, 120^{\circ} 25^{\prime}$ (140440), $16 \mathrm{~km}$ SE Bulloo Downs HS (88818), Nichol Spring (114307), 28km NNE Kumarina (88821), 30km SW Glenburg HS (876289), Carey Downs HS (116754-6*), 16km NNE Mulgul HS (114319), Well 11 Canning Stock Route (40323), McConkey Hill (27990-1), Hope Downs (145663), 220km S Port Hedland (145661), Weld Spring (27992), 12km SSE White Tank (127033), $100 \mathrm{~km}$ NNE Meekatharra (51719), $7 \mathrm{~km} \mathrm{SW}$ Plutonic Well (116380), Errabiddy Stn (46655), $2.5 \mathrm{~km} \mathrm{~N}$ Wilthorpe Well (116378-9), Mungurra Spring, Lake Nabberu (40377), Lorna Glen Stn (145420), Mt Fraser $(106166,114300), 5 \mathrm{~km} \mathrm{~S} \mathrm{Mt}$ Fraser (114287-9), New Springs Stn (97759), 66km $\mathrm{N}$ Meekatharra (113276), 23km N Meekatharra (113273), $5 \mathrm{~km} \mathrm{~N}$ White Well Mooloolgool Stn (132734), Mileura Hill (40225), Lake Carnegie (95247), Jundee (132510), $2 \mathrm{~km} \mathrm{~W} \mathrm{Meekatharra}$ (51713), Mt Lawrence Wells (100298), Mt Fisher (13713), Honeymoon Well (115976), Lake Way HS (87479), $7 \mathrm{~km} \mathrm{~S} \mathrm{Lake} \mathrm{Way} \mathrm{HS} \mathrm{(82585),} 15 \mathrm{~km} \mathrm{E}$ Albion Downs HS (82586), Big Bell (87773), Nallan Stn (97763), Wanjarri (12417), Meka (29280), Yakabindie Stn (104468-9), Yallalong Stn (96670), Mt Sir Samuel (106110), 12km E Ulogunna Rock (132300), 130km NW Mt Magnet (127233), Banjawarn HS (69255-7), $12.5 \mathrm{~km}$ SE Banjawarn (74788), 13km SE Banjawarn (74753), 9km SSE Banjawarn (66015, 69336), Woolgorong Stn (113984, 115260), Duketon (132185), Rosemont Stn (135133), 11km SSE Banjawarn $(66005,66009), 6 \mathrm{~km}$ W Wandarri (34680), $7 \mathrm{~km} \mathrm{~W} \mathrm{Wandarri} \mathrm{(34672),}$ Sandstone (47747), Agnew (46631-3), 8km W Tallering Peak (115072), "Wurarga, Marloo Stn" (ZMB 35353) [Holotype of Lygosoma goerlingi], Mt Magnet $\left(117284^{*}\right), 37 \mathrm{~km}$ E Dandaragan HS (67985), 15km ENE Wildara Pinnacle (141123), Atley Stn (108872-3, 113214-5), 32km NW Mt Windarra (78584), 13km NW Erlistoun (62783), Bundarra HS (66007), $1 \mathrm{~km} \mathrm{~W} \mathrm{Big} \mathrm{Shot} \mathrm{Bore}$ (85309), White Cliffs (20663), 39km E Point Salvation (141152-60), 39km E Laverton (85708-13, $112573-5), 18.5 \mathrm{~km}$ ENE Yuinmery (74661), 8.7km ENE Yuinmery $(66060,74668,74702-3), 8 \mathrm{~km}$ ENE Yuinmery (74651), $7.5 \mathrm{~km}$ E Yuinmery (69033, 69131, 74725-6), Mt Morgans (15687, 86722-9), Burnerbinmah St (140401), Lake Carey (135583), $2 \mathrm{~km}$ SE Wydgie HS (83202-3), $7.5 \mathrm{~km}$ NNW Mt Linden $(72775,72821,72898,74640), 3 \mathrm{~km}$ NE Mt Linden (65914-22), 9.7km SSE Mt Linden (65989), Kookynie (85363-7), 15km SSE Mt Elvire (73396, $73427,78612), 22 \mathrm{~km} \mathrm{~S}$ Mt Elvire (78595, 78643), $5 \mathrm{~km}$ NW Mt Manning Range (73331-2), Mt Manning Range (64743-4, 64776-8), 4km N Mt Manning Range (73342, 73371), $11.5 \mathrm{~km}$ WNW M Manning Range (73330), $2 \mathrm{~km}$ NW Mt Manning
(78685, 78699), Comet Vale (85329), 7.5km E Comet Vale (72746), $6.7 \mathrm{~km} \mathrm{~km} \mathrm{NE} \mathrm{Comet} \mathrm{Vale} \mathrm{(65815),}$ $3.5 \mathrm{~km} \mathrm{NE}$ Comet Vale (65684), Goongarrie Stn (126955, 145315-6, 145386), 5km NW Ora Banda (144916, 144125), Lake Barlee (64779-81), 20km E Paynes Find (49249), 5km E Paynes Find (34692), Paynes Find (117307-8), 9km SW Paynes Find (60929), 12km WSW Paynes Find (141685-8), Ninghan Stn (97762, 140915), 23km SW Yalgoo (117305) , Uwara Nature Reserve (130179, 130377, $130490-1,143850), 39 \mathrm{~km}$ E Lake Collville $(91920$, 92018), 60km SE Blue Robin Hill (92048), 67km SE Blue Robin Hill (92047), 80km SE Blue Robin Hill (91465-6, 92059), 70km NNW Queen Victoria Spring (91254), 53km NNE Queen Victoria Spring (94080-2), 25km NNE Queen Victoria Spring (100936-7, 135292), near Queen Victoria Spring (135290), vicinity of Queen Victoria Spring (117258), Warburton Range (18508-10), 10km S Charlies Knob (99840), Windarling Peak (144545*), $4 \mathrm{~km}$ NNE Mt Jackson Hill (76019-21, 76093-4), Mt Jackson Hill (76059, 76068, 76089, 76098-9, 76104), $4.5 \mathrm{~km}$ NNE Mt Jackson (67010, 72077-8), $1.5 \mathrm{~km} \mathrm{~W}$ Mt Jackson (67007), 1.2km W Mt Jackson (72034, 72062), Mt Jackson (144554-5*, 144566*, 144585), $1.5 \mathrm{~km}$ S Mt Jackson $(67043,67048,67088), 25 \mathrm{~km}$ NE Pittosporum Rockhole $(67147,67167), 12.5 \mathrm{~km}$ SSW Mt Jackson (67025, 67053-4, 72069), 16km SSW Mt Jackson (67009), $18 \mathrm{~km} \mathrm{~S} \mathrm{Mt} \mathrm{Jackson}$ (67092), 18km S Mt Jackson Hill (67002, 76117), $14 \mathrm{~km}$ NE Bungalbin Hill $(67181,76224), 12 \mathrm{kmn}$ NE Bungalbin Hill (67137, 67155, 67172, 67175-6, 72135, 76162), 10km NE Bungalbin Hill (98227), $5 \mathrm{~km} \mathrm{~N}$ Bungalbin Hill $(67198,72163)$, Bungalbin Hill $\left(144706^{*}, 144717^{*}, 144773-774\right)$, Aurora Range (126337, 126349, 126378, 126381), between Carbine and Rowles Lagoon (126590-1*, 126597-8), 8km NW Cundeelee (58733), Cundeelee (18512, 21673), "nine hundred mile peg" [trans Australian railway linel (91512), Kanandah (39721-3), 36km NNE Kitchener (96743, 96747), $21 \mathrm{~km}$ ESE Kitchener (91518), 5km SSE Zanthus (117167), Officer Basin $\left.145071^{*}, 145076^{*}\right)$, Bulong (123903-4, 123926, 123937-8, 123940), $2 \mathrm{~km} \mathrm{~N} \mathrm{Yowie} \mathrm{Rock} \mathrm{Hole}$ (73220), 4km S Yowie Rock Hole (70889), 3.5km SW Black Flag (73271), 5km SE Black Flag (78539), $3 \mathrm{~km}$ S Black Flag (78534), $7 \mathrm{~km}$ WSW Black Flag (73266), $5.5 \mathrm{~km}$ SE Black Flag (73294), $3 \mathrm{~km} \mathrm{SE}$ Boulder (56019), $8 \mathrm{~km}$ E Coonana (146443), $10 \mathrm{~km} \mathrm{~S}$ Kalgoorlie (113573-5, 114695-6), Kangaroo Hills (106038), Kambalda $\left(89264,116287-9^{*}\right), 26 \mathrm{~km} \mathrm{~W}$ Kalgoorlie (114687), 15km NE Karonie (56110), Bullabulling (135125-6), $2 \mathrm{~km} \mathrm{~N}$ Coolgardie (103911, 103917), Boorabbin Nature Reserve (72306), $2 \mathrm{~km}$ SE Boorabbin (74405), 5km SSE Boorabbin (117374), 16km SW Woolgangie (71767, $78713), 15 \mathrm{~km}$ SW Woolgangie (117394-6), $24 \mathrm{~km}$ SSE Woolgangie (78818), $28 \mathrm{~km}$ SSE Woolgangie $\left(78756,117375-6^{*}\right), 31 \mathrm{~km}$ SSE Woolgangie $(78710)$, 


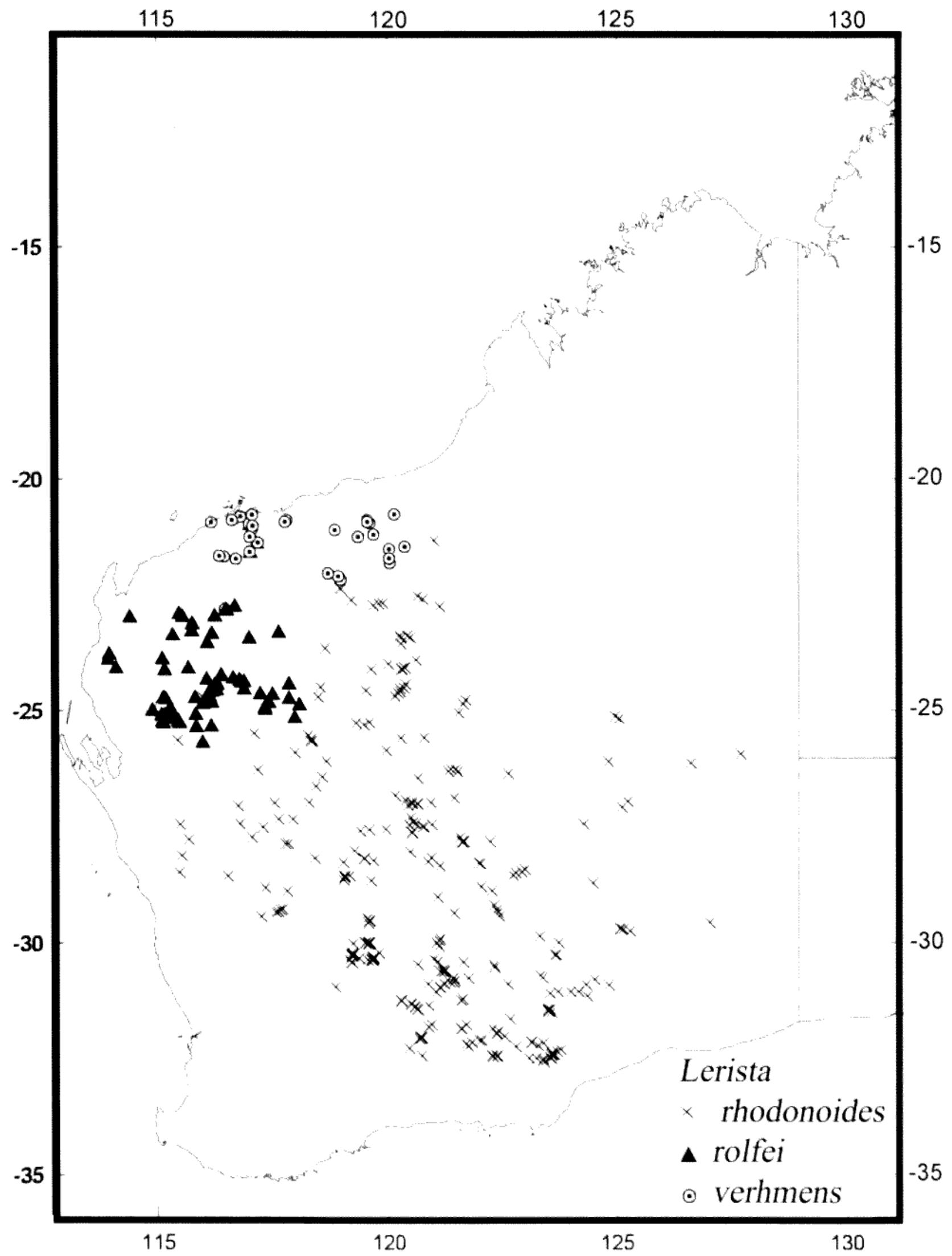

Figure 19 Distribution of L. rhodonoides (in Western Australia), L. rolfei sp. nov. and L. verhmens sp. nov. 
$6 \mathrm{~km} \mathrm{~S}$ Queen Victoria Rock (84220), Higginsville $(127371,127376-8), 48 \mathrm{~km} \mathrm{~S}$ Widgiemooltha (46613), 50km N Norseman (47253), 3km NNE Buningonia Spring $(65574,65601,72462,72508-9$, $74541), 1.5 \mathrm{~km}$ SW Buningonia Spring (65594-5, $72458-9), 3.5 \mathrm{~km}$ SW Buningonia Spring (65532), $6.5 \mathrm{~km}$ SE Buningonia Spring $(65604,72455,72471$ $3), 30 \mathrm{~km} \mathrm{NW}$ Heartbreak Ridge $(65389,72405)$, $20 \mathrm{~km}$ N Heartbreak Ridge $(65368,65442,65488$, $72351,72401,72412), 18 \mathrm{~km} \mathrm{~N}$ Heartbreak Ridge (65374, 65383, 65398-9, 65427, 65477-8, 65509), Heartbreak Ridge ( 72374,72396$), 10 \mathrm{~km} \mathrm{NW}$ Norseman (135203), 35km E Norseman (108860-1), $76 \mathrm{~km}$ E Norseman (34273), 3km E McDermid Rock (65296), 2.5km E McDermid Rock (65284-5, 66163-5, $66167,66173,74254-60,74265,74286,74317-9)$, McDermid Rock (65277, 65346, 74312-3, 74232, $141261), 1.1 \mathrm{~km}$ SE McDermid Rock (66110), $3 \mathrm{~km}$ ESE McDermid Rock (74289), 3.5km SW McDermid Rock (65351), Buldania Rock (18533), 25km E Newman Rock (94189-93), Newman Rock (18531), near Jimberlana Hill (135217), 2km S Southern Hills HS (93417), 8km WNW Maggie Hays Hill (126987), Coolanya Rock (17399-400), Chidalinya Rock (17395), Balladonia Road House (137843-5), $2 \mathrm{~km} \mathrm{~S}$ Balladonia Road House (70002), 6km S Balladonia Road House (137762-3), 13km S Balladonia Road House (93764-8), $11 \mathrm{~km} \mathrm{NW} \mathrm{Clear} \mathrm{Streak} \mathrm{Well}$ (57973), 12km NW Clear Streak Well (59888), $13 \mathrm{~km}$ NW Clear Streak Well (59890-1), 8kmn NNE Clear Streak Well (58008), 20km E Jindabinbin Rockhole (62279), 30km E Jindabinbin Rockhole (62280), Guralia Rock (17388), 19km NNW Charlina Rock (59903), $17 \mathrm{~km}$ NNW Charlina Rock (58030), $12 \mathrm{~km}$ NE Charlina Rock (58012, 59905). The following specimens were included in the allozyme study but not subjected to morphological examination: Wagga Wagga, NSW (SAM38233*), Mulga Dam, SA (SAM41308*), Mootwingie, NSW (SAM45515*), 19k W Mimili, SA (SAM51517*), 35k ESE Amata, SA (SAM51526*), north of Swan Reach, SA (SAM54589*), Coober Pedy, SA (SAM54644*).

\section{Remarks}

Cogger et al. (1983) could only find one of the two syntypes of Ablepharus rhodonoides and presumed one lost. Wells and Wellington (1985) nominated the surviving syntype (AM R4156) as the lectotype. Shea and Sadlier (1999) refer to a single syntype in their list of amphibian and reptile types in the Australian Museum. Thus one syntype is still lost.

It is clear from some of the measurements given by Lucas and Frost (total length $79 \mathrm{~mm}$, body $39 \mathrm{~mm}$, reproduced tail $35 \mathrm{~mm}$ ) that the surviving syntype is not, at least in part, the specimen they described. That they only give a paravertebral count for one specimen and the tail of the surviving specimen is complete (continuation of dark upper lateral stripe can be traced to tip of tail) suggests the original description is mainly based on the missing syntype.

The following is a description of the surviving syntype of Ablepharus rhodonoides (AM R4156).

Nasals large, in short contact (index 2). Prefrontals present, broadly separated. Frontoparietals fused into a single shield. Interparietal free the parietal spot barely discernable. Parietals in broad contact behind interparietal. Nuchals 3 on one side, 4 on the other. Supraoculars three, the first two in contact with the frontal. Supraciliaries five, the first high and just separating the first and second supraoculars, the fifth the smallest. Loreals two, the first about twice as large as the second. Presuboculars two, the first much the larger. Eye ablepharine. One primary temporal. Two secondary temporals, the upper the larger. Upper labials six, fourth under the eye. Infralabials six, the first two contacting the postmental. Three pairs of enlarged chin shields, the second pair separated by a median shield, the third by three scales.

Midbody scales 20. Paravertebrals 74 . SVL $47 \mathrm{~mm}$. TL 61. Lamellae under longest toes 14,15. Lamellae under middle finger 5 .

Back faded brownish-grey. Whitish dorsolateral stripe just discernable. Brownish upper lateral stripe confined to upper third of scale row three and deeply erroded from below. Four rows of dorsal stripes.

Despite its vast geographic range, $L$. rhodonoides exhibits minimal genetic variation (Table 1 ). Moreover, the morphological differences thus far observed between western and eastern populations are few and not very great. Separated nasals is a fairly common condition in eastern rhodonoides. About half the topotypes (type locality of $L$. rhodonoides is Mildura, Victoria) have nasals in point contact or separated, a condition very unusual in western rhodonoides. The tails of eastern rhodonoides may prove to be, on average, shorter than their western counterparts, otherwise there seem to be few differences.

The status of L. timidus (De Vis 1888) is yet to be ascertained. Should it prove conspecific with $L$. rhodonoides, L. timidus would be the senior synonym.

The holotype of Lygosoma (Rhodona) goerlingi is from "Wurarga, Marloo Stn", WA. Western Australian Department of Land Information records show that Marloo Station is now controlled by nearby Gabyon Station and Marloo Stn HS, now only an outstation of Gabyon Station. Marloo out station is at $28^{\circ} 18^{\prime} 58^{\prime \prime} \mathrm{S}, 116^{\circ} 10^{\prime} 56^{\prime \prime} \mathrm{E}$, about $15 \mathrm{~km}$ NW of Wurarga railway station.

The type specimen of Lygosoma goerlingi in the Zoologisches Museum Berlin (35352) was presumed lost (Cogger et al. 1983), but was located by $G$. Shea on a visit to the Berlin Collections in 1989 who subsequently published a detailed description (Shea 1991). 
Lerista rolfei sp. nov.

Figure 20

\section{Holotype}

Western Australian Museum R120575*, an adult male, SVL $38 \mathrm{~mm}$, TL $46 \mathrm{~mm}$. Collected approximately $35 \mathrm{~km}$ SE of Gascoyne Junction, Western Australia at 25¹0'31.4"S, 115²9'18.6"E (site GJ2, Carnarvon Basin Survey) by B. Maryan and A. Desmond on 10 April 1994.

\section{Paratypes}

Wyloo HS (117115-6), 33km ESE Wyloo HS (116730-5), Kooline HS (117100), 25km NNW Winning HS (63667), Barlee Range Nature Reserve (102405-6), 5.4km N Joy Helen Mine (102015, 10201920), 6km S Paraburdoo (83726), 34km NNE Ullawarra HS (25255), Ullawarra Stn (15820), 25km NW Maroonah HS (103291), 1km S Ashburton Downs (84033), Minilya Stn (10613, 18536), 1km N Williambury HS (95741-3), Manberry Stn (9220), Minnie Creek Stn (41901-2), Moogaree HS (62426-7), $5 \mathrm{~km}$ ENE Cobra HS (87669), 3km ESE Cobra HS (87668), 3km W Cobra (87724-6), 24km WNW Mt Augustus (95623-4), 2km NW Mt Augustus (116682), Mt Augustus HS (117020), Mt Augustus (57485, $\left.117121^{*}\right), 20 \mathrm{~km} \mathrm{~S} \mathrm{Mt} \mathrm{Augustus} \mathrm{HS} \mathrm{(84188),} \mathrm{9km} \mathrm{S}$ Yinnietharra HS (116692-3, 116695*-6), 16km S Yinnietharra HS (116724-6, 116764-8), Yinnietharra Stn $(46198,53032), 10 \mathrm{~km}$ S Yinnietharra HS (1274168), 22km SW Yinnietharra HS (87639, 87641), 7km NE Mt Phillips HS (116684), 12km S Mt Phillips HS (116715-23), Mica Well (40544-7), Kennedy Range (106258), 23km NE Waldburg HS (87741), 12km S Waldburg HS (81208), 10-20km S Waldburg HS (81212), 1km W Lyons River HS (87586), $7 \mathrm{~km} \mathrm{~S}$ Draper Bore (108581-2), 26km NW Woodlands HS (87746-9), 2km E Woodlands HS (84105), 22km S Mt Phillips HS (116707-10, 116736-41), 20km NNE Gascoyne Junction (87623-5), approximately $10 \mathrm{~km}$ E Gascoyne Junction [site GJ5, Carnarvon Basin Survey] (120560, 120570, 123309, 123313-6, 123318, 124943, 124958, 124974, 126290-1, 126610), approximately $20 \mathrm{~km}$ ESE Gascoyne Junction [sites GJ3, GJ4 Carnarvon Basin Survey] (120541*,1205434, 120550, 120553, 120556, 120557* 120559, 121497 502, 121504-7, 123332, 123334-6, 123450, 123453 , $123455-7,123459,123788,123797^{*}, 123832,123858$, 124910-2, 124921, 124946-7, 125207, 125211, 125213, 126621), approximately 35km SE Gascoyne Junction [sites GJ1, GJ2, Carnarvon Basin Survey] (12053642, 120561, 120564, 121479, 123425-6, 123774, $123796-7,123818-20,124920,124935 *, 124936$, 125218-9, 125222-4, 125405, 125407-9, 125845, 125851, 125871-4, 126189, 126618), Mooka Stn (108583-4), Gascoyne Junction (87679-82), 16.5km S Gascoyne Junction (116742-43*), 20km S Gascoyne Junction (116686), Dalgety Downs HS (120294), $2 \mathrm{~km}$ SE Dairy Creek HS (87552, 87644), Jimba Jimba

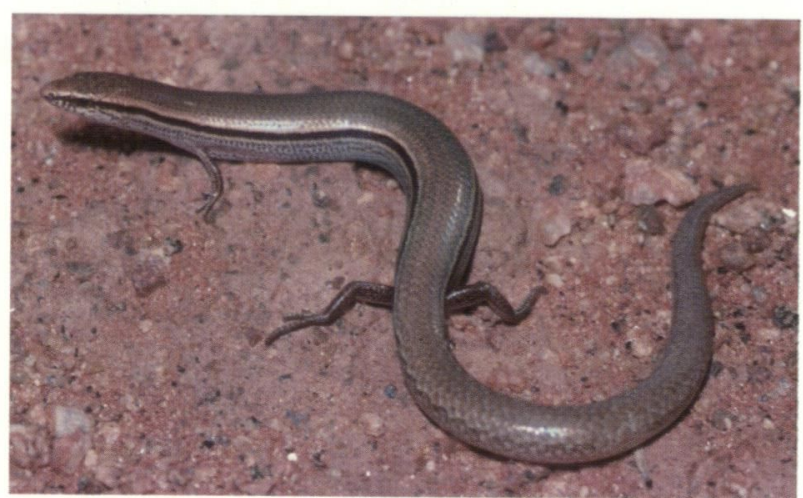

Figure 20 A Lerista rolfei $\mathrm{sp}$. nov. from $1 \mathrm{~km}$ west of Mt Sandiman. Photograph G. Harold.

(100814-5), 24km SSW Glenburg HS (87558), 9 km S Yinnietharra HS (116694*).

\section{Diagnosis}

Distinguished from members of the L. muelleri species group in Western Australia with fused frontoparietals ( $L$. allochira, $L$. amicorum and $L$. rhodonoides) by having paired frontoparietals. Distinguished from those species with paired frontoparietals and fewer than five supraciliaries ( $L$. haroldi, L. jacksoni, L. muelleri and L. nevinae) as follows: from $L$. haroldi by the presence of an upper lateral stripe (absent in L. haroldi), from L. jacksoni by the presence of a hiatus immediately below the upper lateral stripe (L. jacksoni lacks a hiatus); from $L$. muelleri by having five supraciliaries $(1+2$ in $L$. muelleri); and from $L$. nevinae by the absence of a continuous dark paravertebral stripe (present in $L$. nevinae). Distinguished from other species with five supraciliaries and paired frontoparietals ( $L$. clara, $L$. kingi, L. occulta and $L$. verhmens) as follows: from L. clara by having a pigmented venter (opalescent white in L. clara). Lerista kingi, L. occulta and $L$. verhmens have pigmented venters like $L$. rolfei but lack of a hiatus below the upper lateral stripe (hiatus present in L. rolfei).

\section{Description}

SVL 16-48 mm (N 276, mean 35.4). TL 24-88 mm (N 78, mean 44.0). TL\%SVL 102.6-157.1 (N 75, mean 123.3). FL 2.5-5.5 mm (N 270, mean 4.1). FL\%SVL 6.4-16.7 (N 268, mean 11.7). HL 6.0-11.5 mm (N 270, mean 8.8). HL\%SVL 16.7-35.2 (N 268, mean 24.8). Lamellae under middle finger 5-11 (N 167, mean 7.9), under longest toe 12-20 (N 171, mean 15.3), under shortest toe 3-6 (N 169, mean 4.5).

Nasals just touching, in moderate or moderately long contact (mean of index 3.2). Prefrontals widely separated. Frontoparietals and interparietal free. Supraoculars three. Supraciliaries five, the second and fourth smallest. Loreals two, anterior the larger. Nuchals 2-9 (N 266, mean 5.2). Paravertebrals 6091 (N 269, mean 73.4). Midbody scales 20. 
Scale rows one and two olive, light brown or grey, their rows of lineopunctate spots usually weak, sometimes strong. Medial portion of scale row three olive, light brown or grey. Median portion of scale row three almost always with a weak to moderately strong whitish dorsolateral stripe. Lateral portion of scale row three blackishbrown, the dark pigment usually extending to the dorsal $50 \%$ of scale row four (sometimes extending over all of row four), never solid but heavily scalloped on distal margins, sometimes fragmented into vertically aligned blotches. Almost always a whitish hiatus on dorsal half of scale row five. Ventral half of distal row five and all of scale rows six to eight (rarely nine) with irregularly aligned spots and flecks which tend to be prominent due to the paleness of the flanks.

\section{Distribution}

From the Ashburton River Valley in the north and throughout Gascoyne region (Figure 19).

\section{Etymology}

Named for James ('Jim') Rolfe of the Department of Conservation and Land Management since 1984. Still digging pit traps; still contributing reptiles to the Western Australian Museum collections.

\section{Lerista verhmens sp. nov.}

\section{Holotype}

Western Australian Museum R161474, adult female, SVL $48 \mathrm{~mm}$, TL 61 . Collected $19 \mathrm{~km} \mathrm{~W}$ of intersection of Coongan River \& Talga River at $20^{\circ} 53^{\prime} 44.2^{\prime \prime}$, 119³6'7.2"E (site PHYC9, Pilbara Biological Survey) by J. Rolfe on 1 October 2005.

\section{Paratypes}

Coolawanyah (SAM 4476), Asbestos Creek (SAM 4479, 4481), Mt Herbert (20076-7), Harding River Dam (104338), Chichester Range (58956), Millstream-Chichester National Park (131760), Chichester Range (39745), Cape Preston (141369*), Meentheena $\left(139315^{*}\right)$.

\section{Diagnosis}

Distinguished from members of the L. muelleri species group in Western Australia with fused frontoparietals ( $L$. allochira, $L$. amicorum and $L$. rhodonoides) by having paired frontoparietals. Distinguished from those species with paired frontoparietals and fewer than five supraciliaries ( $L$. haroldi, L. jacksoni, L. micra, L. muelleri and $L$. nevinae) by having five supraciliaries. Distinguished from species with paired frontoparietals and five supraciliaries ( $L$. clara, L. kingi, L. occulta, and $L$. rolfei) as follows: from $L$. clara by having a pigmented venter (opalescent white in $L$. clara); and from $L$. kingi by its relatively longer forelimb (mean $13.9 \%$ SVL in $L$. verhmens versus 9.1 in $L$. kingi); from $L$. occulta by its larger size (mean SVL in $L$. verhmens 40.2 versus 30.9 in $L$. occulta) and from $L$. rolfei by the lack of a hiatus below the upper lateral stripe (hiatus present in L. rolfei).

\section{Description}

SVL 25-50 mm (N 13, mean 40.2). TL 61-67 mm (N2, mean $64 \mathrm{~mm}$ ). TL\%SVL127.1-134.0 (N2 mean130.5) FL 4.0-7.5 mm ( N12, mean 5.5). FL\%SVL 9.3-18.0 (N 12, mean 13.9). HL 6.5-10.5 $\mathrm{mm}$ ( $\mathrm{N} \mathrm{12,} \mathrm{mean} \mathrm{9.1).} \mathrm{HL \% SVL} \mathrm{19.0-30.3} \mathrm{(N} \mathrm{12,}$ mean 23.2). Lamellae under middle finger 8-11 ( $N$ 8, mean 9.2), under longest toe 13-19 ( $\mathrm{N} 9$, mean 15.9), under shortest toe 4-6 (N 8, mean 5.0).

Nasals just touching, in moderate or moderately long contact (mean of index 3.3). Prefrontals widely separated. Frontoparietals and interparietal free. Supraoculars three. Supraciliaries five, the second and fourth smallest. Loreals two, anterior the larger. Nuchals 1-6 (N 12, mean 4.7). Paravertebrals 72-84 (N 10, mean 77.9). Midbody scale rows $20(9), 22$ (2).

Scale rows one and two dusky grey, their dark pigment a series of spots, streaks or oblongs. Margins of scales darker grey. On medial third of dorsal row three a suggestion of an irregular lineopunctate row of spots above and abutting the weak to moderately strong pale dorsolateral stripe. Upper lateral stripe varies in width and intensity being narrow and almost solid blackish-brown for the medial third of scale row four or broad (as wide as scale row four) but the dark pigment confined to sutures between scales. Scale rows five to eight dusky with a prominent dark spot at the junction of each scale (most pigment at the anterior of each scale). Belly creamy-white with occasional dark spots. Subcaudals heavily spotted.

\section{Distribution}

Stony hills of the Western Pilbara (Figure 19).

\section{Etymology}

The specific epithet, Latin for powerful, alludes to the robust build of this species.

\section{DISCUSSION}

To a large extent any conclusive discussion of the L. muelleri species group is premature. This work demonstrates the existence of multiple taxa in the western third of the continent but there is still much to learn about the group in eastern Australia. There seems little point in any detailed discussion of the group as a whole until an Australia-wide revision is available for the group.

To date the senior author has examined about 
1100 specimens from South Australia, the southern extremities of the Northern Territory, Victoria, New South Wales and Queensland, in total about three quarters the available specimens from these states and territories. Already seven morphotypes have been identified in South. Australia, two of which spill into the southern parts of the Northern Territory and, while diversity appears much less in New South Wales, Queensland and Victoria, additional species are not unlikely given the complexity encountered to the west. A total of 20 species in the group is therefore not inconceivable.

\section{Adaptions to fossorial habits}

The trend in Lerista and other fossorial squamates is a greater propensity for head shield fusions and the reduction of limb lengths relative to trunk length as species become more fossorial. In terms of fossoriality, the $L$. muelleri species group is very much a 'middle of the road' group when compared with most other Lerista. Most members of the $L$. muelleri species group are not strictly fossorial but leaf litter dwellers. There is variation in the various species' size, limb proportions, degree and nature of head shield fusions and digital formulae. At one extreme there is $L$. muelleri mimicing fossorial species in the $L$. bipes and $L$. nichollsi species groups with fused supraocular/supraciliary conditions. At another extreme there is $L$. clara which, apart from its digital formula, is very much a typical small skink. It is relatively large (up to $49 \mathrm{~mm}$ SVL), has relatively long appendages, there are no head scale fusions and it has a prominent dorsal pattern (particularly a strong upper lateral stripe). Most species are smaller, shorter-limbed, with or without reduced number of supraciliaries, and with or without fused frontoparietals.

From a continental perspective the most striking feature is the geographic distribution of species with paired frontoparietals compared with those with fused frontoparietals. Most, but not all, Western Australian species have the putative ancestral condition of paired frontoparietals. Those that do (with the exception of L. kingi) are found in the Pilbara and along the upper west coast and its hinterland. All non-Western Australian taxa examined have fused frontoparietals and virtually all taxa with fused frontoparietals have southern distributions. In Western Australia the distribution of $L$. rhodonoides is south of, and almost mutually exclusive to, the distribution of species with paired frontoparietals.

Although there are no genetic data to place $L$. amicorum it may, for the time being at least, be considered a northern representative of the 'fused frontoparietal' subgroup, with relatively short forelimbs as for $L$. rhodonoides.

The question as to where L. allochira sits is equivocal. Despite its unique characteristics (one presubocular, two fingers) it is very similar in size and colour pattern to L. micra and $L$. occulta. It is geographically close to $L$. micra and $L$. occulta and may have speciated from either of those species. Alternatively, its fused frontoparietals, qualifies it for the southern subgroup. This being the case it could be considered, along with $L$. amicorum as an outlier of the 'fused frontoparietal' subgroup.

In their review and assessment of the status of Western Australian herpetology Aplin and How (1993) pondered how many cryptic species are still to be discovered and the kinds of taxa that are likely to contain cryptic species. They point out that they are likely to fall into two catagories. The first comprises goegraphically widespread, small to medium-sized, drably or irregularly patterned taxa which are difficult to examine and which defy quantitative description. The second category comprises taxa which can be easily identified in the field and hence do not receive careful examination. The L. muelleri species group qualifies on both counts which may explain why it is proving to be one of the more spectacular examples of a longneglected species group in need of study.

\section{ACKNOWLEDGEMENTS}

We dedicate this work to the late A. M. (Athol) Douglas. We are indebted to Burrup Fertilisers for their financial support with a grant which initiated the genetic analysis in this study. R. Teale, G. Humphries and $\mathrm{K}$. Armstrong of Biota Environmental Sciences provided the impetus for coordinating the funding of that part of the project. P. Kendrick and S. Van Leeuwen (Department of Conservation and Land Management, Karratha) and J. Dell (Department of Environmental Protection, Perth) provided support and encouragement.

G. Shea of the Australian Museum, Sydney, kindly provided us with a copy of his notes on the type of $L$. muelleri rediscovered in the Zoologisches Museum, Museum fur Naturkunde, Berlin. R. Gunther, the curator of reptiles there kindly provided us with the accession details of the Type of $L$. muelleri and the loan of the type of $L$. goerlingi. Thanks also to J. Coventry, former curator of reptiles at the Museum Victoria for the loan of the $L$. 'muelleri' which included the topotypes of $L$. rhodonoides. R. Sadlier of the Australian Museum kindly loaned the type of $L$. rhodonoides.

J. Ruse drew Figure 2 and C. Stevenson prepared the maps. G. Harold, B. Maryan and M. Peterson were, once again, generous with their photographs. T. Reardon provided technical assistance in the allozyme laboratory. B. Maryan, C. Stevenson and P. Doughty assisted with checking the specimen lists and identifications. 


\section{REFERENCES}

Adams, M., Baverstock, P.R., Watts, C.H.S., and Reardon, T. (1987). Electrophoretic resolution of species boundaries in Australian Microchiroptera. I. Eptesicus (Chiroptera, Vespertilionidae). Australian Journal of Biological Sciences 40: 143-162.

Aplin, K.P., and How, R. (1993). A window west: a perspective on Western Australian Herpetology. (pp. 337-345). In: Lunney, D., and Ayers, D. (eds.) Herpetology in Australia: a diverse discipline. Surrey Beatty and Sons, Chipping Norton, NSW, Australia.

Aplin, K.P., and Smith, L.A. (2001). Checklist of the frogs and reptiles of Western Australia in Checklists of the Vertebrates of Western Australia. Records of the Western Australian Museum Supplement 63: 51-74.

Bauer, A.M., Shea, G., and Günther, R. (2003). An annotated catalogue of the types of scincid lizards (Reptilia, Squamata, Scincidae) in the collection of the Museum für Naturkunde der Humbold-Universität zu Berlin (ZMB). Mitteilungen aus dem Museum für Naturkunde in Berlin. Zoologische Reihe 79: 253-321.

Belbin, L. (1994). PATN: Pattern Analysis Package. Reference Manual C.S.I.R.O. Division of Wildlife and Ecology, Gungahlin, Canberra.

Cogger, H.G., Cameron, E.E., and Cogger, H.M. (1983). Zoological Catalogue of Australia 1. Amphibia and Reptilia. Australian Government Publishing Service, Canberra.

Felsenstein, J. (1993). PHYLIP (Phylogeny Inference Package. Version 3.5c). Distributed by the author. University of Washington, Seattle, USA.

Fischer, J.G. (1881). Beschriebung neuer Reptilien. Archiv für Naturgeschte 47: 225-238.

Georges, A., Adams, M., and McCord, W. (2002). Electrophoretic delineation of species boundaries within the genus Chelodina (Testudines: Chelidae) of Australia, New Guinea, and Indonesia. Zoological Journal of the Linnean Society 134: 401-421.

Glauert, L. (1961). Lizards of Western Australia. Handbook No. 6. Western Australian Naturalists' Club, Perth, Western Australia.

Greer, A.E. (1979). A phylogenetic subdivision of Australian skinks. Records of the Australian Museum 32: 339-371.

Greer, A.E. (1990). The taxonomic status of Lerista aericeps Storr, 1986, with a diagnosis of the Lerista orientalis species group. Records of the Western Australian Museum 14: 443-448.

Greer, A.E., McDonald, K.R. and Lawrie, B.C. 1983. Three new species of Lerista (Scincidae) from northern Queensland with a diagnosis of the wilkinsi species group. Journal of Herpetology 17: 247-255.

Greer, A.E., and Shea, G., (2003). Secondary Temporal Scale OverlapPattern: A Character of Possible Broad Systematic Importance in Sphenomorphine Skinks. Journal of Herpetology 37: 545-549.

Kendrick, P.G. (1989). Two new species of Lerista (Lacertilia: Scincidae) from the Cape Range and Kennedy Range of Western Australia. Journal of Herpetology 23: 350-355.

Kendrick, P.G. (1991). The phylogenetics and comparative ecology of Lerista Bell, 1833: patterns of evolution in a genus of sand-swimming skinks. Unpublished PhD Thesis, University of Western Australia, Perth.

Lucas, A.H., and Frost, C. (1896). Description of a new species of Ablepharus from Victoria, with critical notes on two other species of Ausrtalian lizards. Proceedings of the Linnean Society of New South Wales 21: 281-283.

Nei, M. (1978). Estimation of average heterozygosity and genetic distance from a number of individuals. Genetics 89: 583-590.

Page, R.D.M. 1996. TREEVIEW: an application to display phylogenetic trees on personal computers. Comparative. Applied. Bioscience. 12: 357-358.

Pielou, E. C. (1984). The Interpretation of Ecological Data: A Primer on Classification and Ordination. John Wiley, London.

Richardson, B.J., Baverstock, P.R., and Adams, M. (1986). Allozyme Electrophoresis: A Handbook for Animal Systematics and Population Studies. Academic Press, Sydney, NSW.

Rogers, J. S. (1972). Measures of genetic similarity and genetic distance. Studies in Genetics VII -University of Texas Publication number 7213: 145-153.

Schlüter, A., and Hallermann, J. (1997). The type specimens in the Herpetological Collection of the Staatliches Museum für Naturkunde in Stuttgart. Stuttgarter Beiträge. Naturkunde. Serie. A (Biologie) 553: 1-15.

Shea, G.M. (1991). The identity of Lygasoma (Rhodona) goerlingi Ahl, 1935 (Squamata: Scincidae). Records of the Western Australian Museum 15: 303-306.

Shea, G.M., and Sadlier, R. (1999). A catalogue of the non-fossil amphibian and reptile type specimens in the collection of the Australian Museum: types currently, previously and purportedly present. Technical Reports of the Australian Museum 15: 191.

Storr, G.M. (1972). The genus Lerista (Lacertilia: Scincidae) in Western Australia. Journal and Proceedings of the Royal Society of Western Australia 54: 59-75.

Storr, G.M. (1976). Revisionary notes on Lerista (Lacertilia, Scincidae) of Western Australia. Records of the Western Australian Museum 4: 241-256.

Storr, G.M. (1983). Two new lizards from Western Australia (genera Diplodactylus and Lerista). Records of the Western Australian Museum 11: 59-62.

Storr, G.M. (1984). Revision of the Lerista nichollsi complex (Lacertilia: Scincidae). Records of the Western Australian Museum 11: 109-118.

Storr, G.M. (1986). Two new members of the Lerista nichollsi complex (Lacertilia: Scincidae). Records of the Western Australian Museum 13: 47-52.

Storr, G.M. (1991a). Four new members of the Lerista nichollsi complex (Lacertilia: Scincidae). Records of the Western Australian Museum 15: 149-161.

Storr, G.M. (1991b). Revision of Lerista orientalis (Lacertilia: Scincidae) of northern Australia. Records of the Western Australian Museum 15: 413-417. 
Storr, G.M., Smith, L.A. and Johnstone, R.E. (1981). Lizards of Western Australia 1. Skinks. Western Australia Museum Press, Perth.

Storr, G.M., Smith, L.A. and Johnstone, R.E. 1999. Lizards of Western Australia 1. Skinks. Western Australian Museum Press, Perth.

Thorpe, J. P. (1983). Enzyme variation, genetic distance and evolutionary divergence in relation to levels of taxonomic separation (pp. 131-52). In: Oxford. G. S., and Rollinson, D. (eds.) Protein Polymorphism: Adaptive and Taxonomic Significance. Systematics Association Special Volume 24. Academic Press, London.

Wells, R.W. and Wellington, C.R. (1985). A classification of theAmphibia and Reptilia of Australia. Australian Journal of Herpetology Supplementary series 1: 1-61.

Manuscript received 24 June 2004; accepted 29 November 2006 


\section{APPENDIX 1}

Number, range, standard deviation and mean for twelve characters for all species of Lerista in the analysis. Data are presented for males, females and a pooled sample which includes unsexed individuals.

Appendix 1.1. Snout-vent length.

\begin{tabular}{|c|c|c|c|c|c|c|}
\hline SPECIES & CATAGORY & $\mathbf{N}$ & MINIMUM & MAXIMUM & SD & MEAN \\
\hline \multirow[t]{3}{*}{ allochira } & male & 8 & 25 & 35 & 4 & 31 \\
\hline & female & 8 & 32 & 40 & 3 & 36 \\
\hline & all & 21 & 22 & 40 & 4.8 & 32.2 \\
\hline \multirow[t]{3}{*}{ amicorum } & male & 11 & 39 & 45 & 1.8 & 42.3 \\
\hline & female & 10 & 41 & 49 & 2.8 & 44.2 \\
\hline & all & 21 & 39 & 49 & 2.4 & 43.2 \\
\hline \multirow[t]{3}{*}{ clara } & male & 73 & 20 & 47 & 4.4 & 36.9 \\
\hline & female & 53 & 25 & 49 & 5.6 & 39.7 \\
\hline & all & 198 & 20 & 49 & 6.4 & 35.6 \\
\hline \multirow[t]{3}{*}{ haroldi } & male & 1 & 35 & 35 & & 35 \\
\hline & female & 2 & 38 & 40 & 1.4 & 39 \\
\hline & all & 5 & 18 & 40 & 9 & 33.8 \\
\hline \multirow[t]{3}{*}{ jacksoni } & male & 16 & 27 & 36 & 2.3 & 31.8 \\
\hline & female & 18 & 26 & 43 & 3.7 & 34.4 \\
\hline & all & 46 & 17 & 43 & 4.9 & 31.7 \\
\hline \multirow[t]{3}{*}{ kingi } & male & 72 & 32 & 42 & 2.5 & 37.4 \\
\hline & female & 56 & 23 & 46 & 3.9 & 39.3 \\
\hline & all & 151 & 18 & 46 & 4.3 & 37.3 \\
\hline \multirow[t]{3}{*}{ micra } & male & 121 & 25 & 38 & 2.6 & 31.3 \\
\hline & female & 106 & 24 & 46 & 3.7 & 33.9 \\
\hline & all & 418 & 17 & 46 & 4.4 & 30.9 \\
\hline \multirow[t]{3}{*}{ muelleri } & male & 40 & 30 & 41 & 2.5 & 33.9 \\
\hline & female & 32 & 33 & 41 & 2 & 36.5 \\
\hline & all & 89 & 20 & 41 & 3.6 & 34.2 \\
\hline \multirow[t]{3}{*}{ nevinae } & male & 1 & 37 & 37 & & 37 \\
\hline & female & 2 & 34 & 41 & 4.9 & 37.5 \\
\hline & all & 3 & 34 & 41 & 3.5 & 37.3 \\
\hline \multirow[t]{3}{*}{ occulta } & male & 6 & 31 & 34 & 1.2 & 32.3 \\
\hline & female & 2 & 31 & 37 & 4.2 & 34 \\
\hline & all & 27 & 17 & 39 & 5.9 & 30.9 \\
\hline \multirow[t]{3}{*}{ rhodonoides } & male & 229 & 27 & 44 & 2.8 & 37.3 \\
\hline & female & 186 & 27 & 48 & 3.6 & 39.6 \\
\hline & all & 460 & 20 & 49 & 4.3 & 37.7 \\
\hline \multirow[t]{3}{*}{ rolfei } & male & 112 & 25 & 45 & 3.9 & 35.6 \\
\hline & female & 122 & 26 & 46 & 4.8 & 37.9 \\
\hline & all & 276 & 16 & 48 & 5.8 & 35.4 \\
\hline \multirow[t]{3}{*}{ verhmens } & male & 3 & 40 & 44 & 2.3 & 42.7 \\
\hline & female & 5 & 42 & 50 & 3.6 & 46.2 \\
\hline & all & 13 & 25 & 50 & 8.0 & 40.2 \\
\hline
\end{tabular}


Appendix 1.2. Tail length.

\begin{tabular}{|c|c|c|c|c|c|c|}
\hline SPECIES & CATAGORY & $\mathrm{N}$ & MINIMUM & MAXIMUM & $\mathrm{SD}$ & MEAN \\
\hline \multirow[t]{3}{*}{ allochira } & males & 1 & 37 & 37 & & 37.0 \\
\hline & females & 1 & 36 & 36 & & 36.0 \\
\hline & all & 4 & 31 & 37 & 2.6 & 34.7 \\
\hline \multirow[t]{3}{*}{ amicorum } & males & 6 & 50 & 53 & 1.0 & 51.7 \\
\hline & females & 3 & 49 & 55 & 3.2 & 52.7 \\
\hline & all & 9 & 49 & 55 & 1.9 & 52.0 \\
\hline \multirow[t]{3}{*}{ clara } & males & 23 & 34 & 55 & 5.4 & 46.1 \\
\hline & females & 9 & 30 & 58 & 8.4 & 48.7 \\
\hline & all & 41 & 23 & 58 & 7.7 & 45.1 \\
\hline \multirow[t]{3}{*}{ haroldi } & males & 0 & & & & \\
\hline & females & 0 & & & & \\
\hline & all & 1 & 45 & 45 & & 45.0 \\
\hline \multirow[t]{3}{*}{ jacksoni } & males & 7 & 33 & 43 & 3.9 & 37.4 \\
\hline & females & 2 & 37 & 52 & 6.0 & 43.2 \\
\hline & all & 13 & 33 & 52 & 5.3 & 40.0 \\
\hline \multirow[t]{3}{*}{ kingi } & males & 16 & 40 & 50 & 2.6 & 43.4 \\
\hline & females & 10 & 35 & 52 & 5.2 & 44.1 \\
\hline & all & 32 & 22 & 52 & 5.8 & 41.9 \\
\hline \multirow[t]{3}{*}{ micra } & males & 35 & 25 & 45 & 5.3 & 37.7 \\
\hline & females & 25 & 26 & 53 & 6.0 & 38.7 \\
\hline & all & 113 & 23 & 53 & 5.8 & 36.3 \\
\hline \multirow[t]{3}{*}{ muelleri } & males & 7 & 38 & 46 & 3.3 & 43.3 \\
\hline & females & 8 & 40 & 54 & 4.0 & 46.2 \\
\hline & all & 18 & 31 & 54 & 5.0 & 44.2 \\
\hline \multirow[t]{3}{*}{ nevinae } & males & 1 & 46 & 46 & & 48.0 \\
\hline & females & 1 & 42 & 42 & & 42.0 \\
\hline & all & 2 & 42 & 46 & 2.8 & 44.0 \\
\hline \multirow[t]{3}{*}{ occulta } & males & 0 & & & & \\
\hline & females & 0 & & & & \\
\hline & all & 3 & 32 & 41 & 4.5 & 36.3 \\
\hline \multirow[t]{3}{*}{ rhodonoides } & males & 58 & 32 & 55 & 4.7 & 43.3 \\
\hline & females & 37 & 39 & 60 & 4.8 & 45.6 \\
\hline & all & 118 & 22 & 60 & 5.5 & 43.3 \\
\hline \multirow[t]{3}{*}{ rolfei } & males & 34 & 34 & 55 & 5.8 & 45.2 \\
\hline & females & 25 & 31 & 88 & 11.0 & 48.9 \\
\hline & all & 78 & 24 & 88 & 9.7 & 44.0 \\
\hline \multirow[t]{3}{*}{ verhmens } & males & 0 & & & & \\
\hline & females & 2 & 61 & 67 & & 64.0 \\
\hline & all & 2 & 61 & 67 & & 64.0 \\
\hline
\end{tabular}


Appendix 1.3 Relative length of tail (percentage of SVL).

\begin{tabular}{|c|c|c|c|c|c|c|}
\hline SPECIES & CATAGORY & $\mathbf{N}$ & MINIMUM & MAXIMUM & SD & MEAN \\
\hline \multirow[t]{3}{*}{ allochira } & male & 1 & 112.2 & 112.2 & & 112.2 \\
\hline & female & 1 & 109.1 & 109.1 & & 109.1 \\
\hline & all & 4 & 109.1 & 140.9 & 14.8 & 118.7 \\
\hline \multirow[t]{3}{*}{ amicorum } & male & 6 & 116.3 & 133.3 & 6.2 & 122.2 \\
\hline & female & 3 & 100.0 & 140.0 & 17.2 & 119.8 \\
\hline & all & 9 & 100.0 & 133.3 & 9.9 & 121.4 \\
\hline \multirow[t]{3}{*}{ clara } & male & 14 & 114.3 & 170 & 13.8 & 132.5 \\
\hline & female & 9 & 109.8 & 148.7 & 11.4 & 124.1 \\
\hline & all & 41 & 109.8 & 170 & 14.5 & 129.3 \\
\hline \multirow[t]{3}{*}{ haroldi } & male & 0 & & & & \\
\hline & female & 0 & & & & \\
\hline & all & 1 & 118.4 & 118.4 & & 118.4 \\
\hline \multirow[t]{3}{*}{ jacksoni } & male & 6 & 103.0 & 138.7 & 13.1 & 116.5 \\
\hline & female & 5 & 119.3 & 162.2 & 17.6 & 135.8 \\
\hline & all & 13 & 103.0 & 162.5 & 17.4 & 125.5 \\
\hline \multirow[t]{3}{*}{ kingi } & male & 16 & 105.1 & 131.6 & 8.0 & 116.7 \\
\hline & female & 10 & 106.1 & 128.6 & 7.5 & 116.3 \\
\hline & all & 32 & 105.1 & 131.6 & 7.4 & 116.0 \\
\hline \multirow[t]{3}{*}{ micra } & male & 30 & 106.2 & 146.4 & 10.5 & 124.0 \\
\hline & female & 25 & 102.7 & 139.5 & 9.5 & 118.0 \\
\hline & all & 104 & 102.7 & 146.3 & 10.3 & 121.0 \\
\hline \multirow[t]{3}{*}{ muelleri } & male & 7 & 112.2 & 131.4 & 7.4 & 123.0 \\
\hline & female & 8 & 111.1 & 142.1 & 11.1 & 123.5 \\
\hline & all & 18 & 106.9 & 142.1 & 9.2 & 122.3 \\
\hline \multirow[t]{3}{*}{ nevinae } & male & 1 & 124.3 & 124.3 & & 124.3 \\
\hline & female & 1 & 123.5 & 123.5 & & 123.5 \\
\hline & all & 2 & 123.5 & 124.3 & 0.6 & 123.9 \\
\hline \multirow[t]{3}{*}{ occulta } & male & 0 & & & & \\
\hline & female & 0 & & & & \\
\hline & all & 3 & 100.0 & 117.4 & 9.9 & 105.7 \\
\hline \multirow[t]{3}{*}{ rhodonoides } & male & 54 & 105.3 & 140 & 8.7 & 118.8 \\
\hline & female & 31 & 102.4 & 151.3 & 11.4 & 117.7 \\
\hline & all & 102 & 102.3 & 151.3 & 9.6 & 117.3 \\
\hline \multirow[t]{3}{*}{ rolfei } & male & 34 & 102.6 & 157.1 & 13.8 & 124.8 \\
\hline & female & 23 & 103.3 & 143.7 & 10.7 & 125.5 \\
\hline & all & 75 & 102.6 & 157.1 & 12.1 & 123.3 \\
\hline \multirow[t]{3}{*}{ verhmens } & male & 0 & & & & \\
\hline & female & 2 & 127.1 & 134.0 & & 130.5 \\
\hline & all & 2 & 127.1 & 134.0 & & 130.5 \\
\hline
\end{tabular}


Appendix 1.4. Length of foreleg.

\begin{tabular}{|c|c|c|c|c|c|c|}
\hline SPECIES & CATEGORY & $\mathbf{N}$ & MINIMUM & MAXIMUM & SD & MEAN \\
\hline \multirow[t]{3}{*}{ allochira } & male & 8 & 2.5 & 3.5 & 0.2 & 3 \\
\hline & female & 8 & 2.5 & 3.5 & 0.4 & 3.1 \\
\hline & all & 21 & 2.5 & 3.5 & 0.3 & 3.1 \\
\hline \multirow[t]{3}{*}{ amicorum } & male & 11 & 4 & 5 & 0.4 & 4.4 \\
\hline & female & 10 & 4.0 & 5.0 & 0.3 & 4.4 \\
\hline & all & 21 & 4 & 5.0 & 0.4 & 4.4 \\
\hline \multirow[t]{3}{*}{ clara } & male & 58 & 2.5 & 5.5 & 0.7 & 4.4 \\
\hline & female & 46 & 3 & 5.5 & 0.6 & 4.4 \\
\hline & all & 151 & 2.5 & 5.5 & 0.7 & 4.3 \\
\hline \multirow[t]{3}{*}{ haroldi } & male & 1 & 5 & 5 & & 5 \\
\hline & female & 3 & 3.5 & 4.5 & 0.6 & 4.1 \\
\hline & all & 5 & 3.5 & 5 & 0.7 & 4.2 \\
\hline \multirow[t]{3}{*}{ jacksoni } & male & 16 & 3 & 4 & 0.2 & 3.5 \\
\hline & female & 18 & 2 & 4 & 0.4 & 3.5 \\
\hline & all & 45 & 2 & 4 & 0.4 & 3.4 \\
\hline \multirow[t]{3}{*}{ kingi } & male & 69 & 3 & 5 & 0.4 & 3.4 \\
\hline & female & 54 & 2.5 & 4 & 0.3 & 3.3 \\
\hline & all & 143 & 2.5 & 5.0 & 0.4 & 3.4 \\
\hline \multirow[t]{3}{*}{ micra } & male & 118 & 2 & 9.5 & 1 & 3.6 \\
\hline & female & 103 & 2.5 & 9 & 1 & 3.6 \\
\hline & all & 336 & 2 & 9.5 & 0.9 & 3.5 \\
\hline \multirow[t]{3}{*}{ muelleri } & male & 24 & 2.5 & 4.5 & 0.5 & 3.4 \\
\hline & female & 23 & 2.5 & 4 & 0.5 & 3.3 \\
\hline & all & 59 & 2.5 & 4.5 & 0.5 & 3.4 \\
\hline \multirow[t]{3}{*}{ nevinae } & male & 1 & 5 & 5 & & 5 \\
\hline & female & 2 & 5 & 5.5 & 0 & 5.2 \\
\hline & all & 3 & 5 & 5.5 & 0.3 & 5.2 \\
\hline \multirow[t]{3}{*}{ occulta } & male & 6 & 4 & 8.5 & 2.2 & 5.4 \\
\hline & female & 2 & 3.5 & 3.5 & 0 & 3.5 \\
\hline & all & 20 & 3 & 8.5 & 1.7 & 4.3 \\
\hline \multirow[t]{3}{*}{ rhodonoides } & male & 164 & 2.5 & 5 & 0.5 & 3.6 \\
\hline & female & 132 & 2.5 & 5.5 & 0.4 & 3.5 \\
\hline & all & 340 & 2.5 & 5.5 & 0.5 & 3.5 \\
\hline \multirow[t]{3}{*}{ rolfei } & male & 103 & 2.5 & 5.5 & 0.8 & 4.3 \\
\hline & female & 117 & 2.5 & 5.5 & 0.7 & 4.1 \\
\hline & all & 270 & 2.5 & 5.5 & 0.8 & 4.1 \\
\hline \multirow[t]{3}{*}{ verhmens } & male & 3 & 6 & 6.5 & 0.3 & 6.2 \\
\hline & female & 5 & 4 & 7.5 & 1.3 & 5.8 \\
\hline & all & 12 & 4 & 7.5 & 1.1 & 5.5 \\
\hline
\end{tabular}


Appendix 1.5. Relative length of FL (as percentage of SVL).

\begin{tabular}{|c|c|c|c|c|c|c|}
\hline SPECIES & CATAGORY & $\mathbf{N}$ & MINIMUM & MAXIMUM & SD & MEAN \\
\hline \multirow[t]{3}{*}{ allochira } & male & 8 & 7.6 & 12 & 1.6 & 9.8 \\
\hline & female & 8 & 6.9 & 10.3 & 1.3 & 8.5 \\
\hline & all & 21 & 6.9 & 13.6 & 1.9 & 9.8 \\
\hline \multirow[t]{3}{*}{ amicorum } & male & 11 & 8.9 & 11.6 & 1.0 & 10.3 \\
\hline & female & 10 & 8.2 & 12.2 & 1.1 & 9.9 \\
\hline & all & 21 & 8.2 & 12.2 & 1.0 & 10.1 \\
\hline \multirow[t]{3}{*}{ clara } & male & 58 & 7.3 & 20 & 1.8 & 12.2 \\
\hline & female & 46 & 7.5 & 18 & 2.0 & 11.5 \\
\hline & all & 151 & 7.3 & 20 & 2.1 & 12.2 \\
\hline \multirow[t]{3}{*}{ haroldi } & male & 1 & 14.3 & 14.3 & & 14.3 \\
\hline & female & 2 & 11.2 & 11.8 & 0.4 & 11.5 \\
\hline & all & 4 & 9.2 & 14.3 & 2.1 & 11.6 \\
\hline \multirow[t]{3}{*}{ jacksoni } & male & 16 & 9.1 & 13.3 & 1.3 & 11.0 \\
\hline & female & 18 & 7.7 & 11.7 & 0.9 & 10.1 \\
\hline & all & 45 & 7.1 & 17.6 & 1.9 & 10.8 \\
\hline \multirow[t]{3}{*}{ kingi } & male & 69 & 7.3 & 12.5 & 1.1 & 9.2 \\
\hline & female & 54 & 6.6 & 11.4 & 1.0 & 8.5 \\
\hline & all & 143 & 6.6 & 16.7 & 1.4 & 9.1 \\
\hline \multirow[t]{3}{*}{ micra } & male & 118 & 8 & 27.2 & 2.8 & 11.5 \\
\hline & female & 102 & 6.7 & 25 & 2.9 & 10.8 \\
\hline & all & 336 & 6.7 & 31.5 & 2.8 & 11.4 \\
\hline \multirow[t]{3}{*}{ muelleri } & male & 24 & 7.1 & 13.6 & 1.7 & 10.2 \\
\hline & female & 23 & 6.6 & 12.1 & 1.6 & 9.1 \\
\hline & all & 59 & 6.6 & 13.6 & 1.5 & 9.9 \\
\hline \multirow[t]{3}{*}{ nevinae } & male & 1 & 13.5 & 13.5 & & 13.5 \\
\hline & female & 2 & 13.4 & 14.7 & 0.9 & 14.1 \\
\hline & all & 3 & 13.4 & 14.7 & 0.7 & 13.9 \\
\hline \multirow[t]{3}{*}{ occulta } & male & 6 & 11.8 & 25.7 & 6.7 & 16.7 \\
\hline & female & 2 & 9.4 & 11.3 & 1.3 & 10.3 \\
\hline & all & 20 & 8.3 & 26.4 & 5.5 & 13.9 \\
\hline \multirow[t]{3}{*}{ rhodonoides } & male & 162 & 5.9 & 14.0 & 1.4 & 9.7 \\
\hline & female & 131 & 6.1 & 14.1 & 1.3 & 8.9 \\
\hline & all & 354 & 5.9 & 14.3 & 1.4 & 9.4 \\
\hline \multirow[t]{3}{*}{ rolfei } & male & 102 & 6.7 & 16.6 & 1.9 & 12.1 \\
\hline & female & 116 & 6.4 & 16.6 & 1.9 & 10.9 \\
\hline & all & 268 & 6.4 & 16.7 & 2.0 & 11.7 \\
\hline \multirow[t]{3}{*}{ verhmens } & male & 3 & 13.6 & 15.0 & 0.7 & 14.4 \\
\hline & female & 5 & 9.3 & 15.9 & 2.3 & 12.5 \\
\hline & all & 12 & 9.3 & 18.0 & 2.2 & 13.9 \\
\hline
\end{tabular}


Appendix 1.6. Length of hindlimb.

\begin{tabular}{|c|c|c|c|c|c|c|}
\hline SPECIES & CATAGORY & $\mathbf{N}$ & MINIMUM & MAXIMUM & SD & MEAN \\
\hline \multirow[t]{3}{*}{ allochira } & male & 8 & 4.5 & 7.5 & 1 & 6.1 \\
\hline & female & 8 & 6 & 7 & 0.3 & 6.5 \\
\hline & all & 21 & 4.5 & 7.5 & 0.7 & 6.2 \\
\hline \multirow[t]{3}{*}{ amicorum } & male & 11 & 7.5 & 10.5 & 0.9 & 9.5 \\
\hline & female & 10 & 8.0 & 10.5 & 0.7 & 9.4 \\
\hline & all & 21 & 7.5 & 10.5 & 0.8 & 9.4 \\
\hline \multirow[t]{3}{*}{ clara } & male & 58 & 7 & 12 & 1.1 & 9.0 \\
\hline & female & 47 & 6 & 10 & 1.4 & 8.8 \\
\hline & all & 151 & 5.5 & 12 & 1.3 & 8.5 \\
\hline \multirow[t]{3}{*}{ haroldi } & male & 1 & 8 & 8 & & 8.0 \\
\hline & female & 3 & 9 & 10 & 0.6 & 9.3 \\
\hline & all & 5 & 8 & 10 & 0.8 & 8.8 \\
\hline \multirow[t]{3}{*}{ jacksoni } & male & 16 & 4.5 & 8 & 0.8 & 6.2 \\
\hline & female & 17 & 5 & 7 & 0.7 & 6.1 \\
\hline & all & 44 & 4.5 & 8 & 0.8 & 6.0 \\
\hline \multirow[t]{3}{*}{ kingi } & male & 70 & 7 & 10 & 0.7 & 8.7 \\
\hline & female & 54 & 6.5 & 10 & 0.8 & 8.2 \\
\hline & all & 143 & 6 & 10 & 0.8 & 8.4 \\
\hline \multirow[t]{3}{*}{ micra } & male & 119 & 5.5 & 10 & 0.9 & 8.0 \\
\hline & female & 106 & 2.5 & 9.5 & 1.1 & 7.8 \\
\hline & all & 340 & 2.5 & 10 & 1.0 & 7.7 \\
\hline \multirow[t]{3}{*}{ muelleri } & male & 24 & 5.5 & 8.5 & 0.7 & 6.6 \\
\hline & female & 23 & 5 & 8 & 0.8 & 6.0 \\
\hline & all & 59 & 5 & 8.5 & 0.9 & 6.2 \\
\hline \multirow[t]{3}{*}{ nevinae } & male & 1 & 9.5 & 9.5 & & 9.5 \\
\hline & female & 2 & 9 & 11.5 & 1.8 & 10.2 \\
\hline & all & 3 & 9 & 11.5 & 1.3 & 10 \\
\hline \multirow[t]{3}{*}{ occulta } & male & 6 & 7.5 & 9 & 0.6 & 8.0 \\
\hline & female & 2 & 7 & 7.5 & 0.3 & 7.2 \\
\hline & all & 20 & 3 & 9 & 1.3 & 7.1 \\
\hline \multirow[t]{3}{*}{ rhodonoides } & male & 164 & 6 & 12 & 0.9 & 8.4 \\
\hline & female & 130 & 5.5 & 10.5 & 0.9 & 8.2 \\
\hline & all & 356 & 5.5 & 12 & 0.9 & 8.3 \\
\hline \multirow[t]{3}{*}{ rolfei } & male & 104 & 6.0 & 11.5 & 1.1 & 8.9 \\
\hline & female & 116 & 6.5 & 11.5 & 1.0 & 8.9 \\
\hline & all & 270 & 6 & 11.5 & 1.1 & 8.8 \\
\hline \multirow[t]{3}{*}{ verhmens } & male & 3 & 9.5 & 10 & 0.3 & 9.7 \\
\hline & female & 5 & 9.5 & 10.5 & 0.4 & 9.8 \\
\hline & all & 12 & 6.5 & 10.5 & 1.2 & 9.1 \\
\hline
\end{tabular}


Appendix 1.7. Relative length of hindleg (as percentage of SVL).

\begin{tabular}{|c|c|c|c|c|c|c|}
\hline SPECIES & CATAGORY & $\mathbf{N}$ & MINIMUM & MAXIMUM & SD & MEAN \\
\hline \multirow[t]{3}{*}{ allochira } & male & 8 & 17.7 & 22.0 & 1.7 & 19.7 \\
\hline & female & 8 & 16.2 & 19.7 & 1.0 & 18.3 \\
\hline & all & 21 & 16.2 & 29.5 & 2.7 & 19.5 \\
\hline \multirow[t]{3}{*}{ amicorum } & male & 11 & 17.4 & 25.6 & 2.2 & 22.5 \\
\hline & female & 10 & 17.4 & 25.6 & 2.1 & 22.5 \\
\hline & all & 21 & 17.4 & 25.6 & 2.2 & 21.9 \\
\hline \multirow[t]{3}{*}{ clara } & male & 58 & 18.3 & 35.4 & 3.1 & 24.7 \\
\hline & female & 47 & 17.1 & 28.0 & 2.6 & 22.6 \\
\hline & all & 151 & 17.1 & 35.4 & 3.3 & 24.1 \\
\hline \multirow[t]{3}{*}{ haroldi } & male & 1 & 22.8 & 22.8 & & 22.8 \\
\hline & female & 2 & 23.6 & 25.0 & 0.9 & 24.3 \\
\hline & all & 4 & 21.0 & 25.0 & 1.6 & 23.1 \\
\hline \multirow[t]{3}{*}{ jacksoni } & male & 16 & 15.3 & 26.7 & 2.8 & 19.6 \\
\hline & female & 17 & 14.1 & 21.7 & 2.0 & 18.0 \\
\hline & all & 44 & 14.1 & 26.7 & 2.8 & 19.0 \\
\hline \multirow[t]{3}{*}{ kingi } & male & 70 & 18.4 & 28.1 & 2.3 & 23.4 \\
\hline & female & 54 & 15.1 & 25.7 & 2.4 & 20.8 \\
\hline & all & 143 & 15.1 & 33.3 & 2.8 & 22.5 \\
\hline \multirow[t]{3}{*}{ micra } & male & 119 & 17.2 & 31.7 & 2.4 & 25.4 \\
\hline & female & 105 & 7.1 & 30.3 & 3.2 & 23.1 \\
\hline & all & 338 & 7.1 & 35.0 & 3.2 & 24.8 \\
\hline \multirow[t]{3}{*}{ muelleri } & male & 24 & 15.7 & 23.6 & 2.3 & 19.4 \\
\hline & female & 23 & 12.8 & 20.3 & 2.2 & 16.6 \\
\hline & all & 59 & 12.8 & 25.0 & 2.8 & 18.1 \\
\hline \multirow[t]{3}{*}{ nevinae } & male & 1 & 25.7 & 25.7 & & 25.7 \\
\hline & female & 2 & 21.9 & 33.8 & 8.4 & 27.9 \\
\hline & all & 3 & 21.9 & 33.8 & 6.0 & 27.1 \\
\hline \multirow[t]{3}{*}{ occulta } & male & 6 & 22.0 & 27.3 & 1.7 & 24.7 \\
\hline & female & 2 & 20.3 & 22.6 & 1.6 & 21.4 \\
\hline & all & 20 & 17.6 & 30.8 & 3.1 & 22.3 \\
\hline \multirow[t]{3}{*}{ rhodonoides } & male & 163 & 14.3 & 29.7 & 2.6 & 22.7 \\
\hline & female & 129 & 15.2 & 28.1 & 2.6 & 20.7 \\
\hline & all & 354 & 14.3 & 30.0 & 2.8 & 22.1 \\
\hline \multirow[t]{3}{*}{ rolfei } & male & 103 & 16.6 & 33.3 & 3.0 & 25.2 \\
\hline & female & 115 & 17.0 & 30.8 & 3.0 & 23.6 \\
\hline & all & 268 & 16.7 & 35.2 & 3.3 & 24.8 \\
\hline \multirow[t]{3}{*}{ verhmens } & male & 3 & 21.6 & 23.8 & 1.1 & 22.7 \\
\hline & female & 5 & 19 & 22.6 & 1.4 & 21.2 \\
\hline & all & 12 & 19 & 30.3 & 2.9 & 23.2 \\
\hline
\end{tabular}


Appendix 1.8. Number of lamellae under middle finger.

\begin{tabular}{|c|c|c|c|c|c|c|}
\hline SPECIES & CATEGORY & $\mathbf{N}$ & MINIMUM & MAXIMUM & SD & MEAN \\
\hline \multirow[t]{3}{*}{ amicorum } & male & 9 & 5 & 10 & 1.6 & 7.1 \\
\hline & female & 10 & 5 & 9 & 1.4 & 7.5 \\
\hline & all & 19 & 5 & 10 & 1.5 & 7.3 \\
\hline \multirow[t]{3}{*}{ clara } & male & 50 & 6 & 12 & 1.3 & 8.4 \\
\hline & female & 46 & 7 & 12 & 1.1 & 8.5 \\
\hline & all & 127 & 6 & 12 & 1.2 & 8.3 \\
\hline \multirow[t]{3}{*}{ haroldi } & male & 0 & & & & \\
\hline & female & 2 & 7 & 8 & 0.7 & 7.5 \\
\hline & all & 2 & 7 & 8 & 0.7 & 7.5 \\
\hline \multirow[t]{3}{*}{ jacksoni } & male & 14 & 6 & 11 & 1.3 & 7.6 \\
\hline & female & 15 & 7 & 10 & 1.0 & 8.0 \\
\hline & all & 35 & 5 & 11 & 1.3 & 7.8 \\
\hline \multirow[t]{3}{*}{ kingi } & male & 34 & 5 & 8 & 0.8 & 6.6 \\
\hline & female & 42 & 5 & 9 & 0.9 & 6.6 \\
\hline & all & 80 & 5 & 9 & 0.9 & 6.6 \\
\hline \multirow[t]{3}{*}{ micra } & male & 59 & 5 & 10 & 1.1 & 7.3 \\
\hline & female & 59 & 5 & 11 & 1.3 & 7.2 \\
\hline & all & 147 & 5 & 11 & 1.3 & 7.2 \\
\hline \multirow[t]{3}{*}{ muelleri } & male & 20 & 6 & 12 & 1.5 & 8.0 \\
\hline & female & 19 & 5 & 9 & 1.0 & 7.4 \\
\hline & all & 49 & 5 & 12 & 1.3 & 7.6 \\
\hline \multirow[t]{3}{*}{ nevinae } & male & 1 & 8 & 8 & & 8.0 \\
\hline & female & 2 & 7 & 8 & 0.7 & 7.5 \\
\hline & all & 3 & 7 & 8 & 0.6 & 7.6 \\
\hline \multirow[t]{3}{*}{ occulta } & male & 4 & 6 & 9 & 1.2 & 7.2 \\
\hline & female & 1 & 7 & & & 7.0 \\
\hline & all & 10 & 6 & 9 & 0.9 & 7.0 \\
\hline \multirow[t]{3}{*}{ rhodonoides } & male & 113 & 3 & 12 & 1.1 & 7.1 \\
\hline & female & 97 & 4 & 11 & 1.1 & 7.0 \\
\hline & all & 221 & 3 & 12 & 1.1 & 7.1 \\
\hline \multirow[t]{3}{*}{ rolfei } & male & 62 & 5 & 10 & 1.1 & 7.8 \\
\hline & female & 86 & 6 & 11 & 1.3 & 8.0 \\
\hline & all & 167 & 5 & 11 & 1.2 & 7.9 \\
\hline \multirow[t]{3}{*}{ verhmens } & male & 3 & 8 & 9 & 0.5 & 8.3 \\
\hline & female & 5 & 8 & 11 & 1.3 & 9.8 \\
\hline & all & 8 & 8 & 11 & 1.3 & 9.2 \\
\hline
\end{tabular}


Appendix 1.9. Number of lamellae under longest toe.

\begin{tabular}{|c|c|c|c|c|c|c|}
\hline SPECIES & CATAGORY & $\mathbf{N}$ & MINIMUM & MAXIMUM & SD & MEAN \\
\hline \multirow[t]{3}{*}{ allochira } & male & 6 & 11 & 15 & 1.5 & 12.7 \\
\hline & female & 6 & 5 & 13 & 2.9 & 10.3 \\
\hline & all & 17 & 5 & 15 & 2.0 & 11.9 \\
\hline \multirow[t]{3}{*}{ amicorum } & male & 10 & 13 & 16 & 1.1 & 14.0 \\
\hline & female & 10 & 13 & 18 & 1.6 & 15.5 \\
\hline & all & 20 & 13 & 18 & 1.5 & 14.8 \\
\hline \multirow[t]{3}{*}{ clara } & male & 50 & 11 & 20 & 1.9 & 15.7 \\
\hline & female & 47 & 12 & 19 & 1.8 & 16.1 \\
\hline & all & 134 & 11 & 20 & 1.9 & 15.8 \\
\hline \multirow[t]{3}{*}{ haroldi } & male & 0 & & & & \\
\hline & female & 2 & 13 & 14 & 0.7 & 13.5 \\
\hline & all & 4 & 13 & 14 & 0.6 & 13.5 \\
\hline \multirow[t]{3}{*}{ jacksoni } & male & 14 & 12 & 17 & 1.7 & 14.6 \\
\hline & female & 17 & 11 & 19 & 2.0 & 15.5 \\
\hline & all & 39 & 11 & 19 & 1.9 & 14.8 \\
\hline \multirow[t]{3}{*}{ kingi } & male & 34 & 10 & 17 & 1.7 & 13.8 \\
\hline & female & 43 & 10 & 18 & 1.8 & 14.0 \\
\hline & all & 82 & 10 & 18 & 1.7 & 14.0 \\
\hline \multirow[t]{3}{*}{ micra } & male & 61 & 10 & 17 & 1.7 & 13.9 \\
\hline & female & 59 & 10 & 19 & 1.8 & 14.7 \\
\hline & all & 147 & 10 & 19 & 1.9 & 14.3 \\
\hline \multirow[t]{3}{*}{ muelleri } & male & 20 & 13 & 20 & 2.2 & 15.8 \\
\hline & female & 19 & 12 & 20 & 1.8 & 15.2 \\
\hline & all & 47 & 12 & 20 & 2.0 & 15.4 \\
\hline \multirow[t]{3}{*}{ nevinae } & male & 1 & 15 & 15 & & 15.0 \\
\hline & female & 2 & 16 & 16 & & 16.0 \\
\hline & all & 3 & 15 & 16 & 0.6 & 15.7 \\
\hline \multirow[t]{3}{*}{ occulta } & male & 6 & 11 & 15 & 1.6 & 12.6 \\
\hline & female & 2 & 16 & 17 & 0.7 & 16.5 \\
\hline & all & 15 & 11 & 17 & 2.0 & 13.8 \\
\hline \multirow[t]{3}{*}{ rhodonoides } & male & 116 & 11 & 20 & 1.8 & 14.9 \\
\hline & female & 94 & 10 & 19 & 1.9 & 14.6 \\
\hline & all & 226 & 10 & 20 & 1.8 & 14.8 \\
\hline \multirow[t]{3}{*}{ rolfei } & male & 64 & 12 & 20 & 1.9 & 15.2 \\
\hline & female & 87 & 13 & 20 & 1.6 & 15.6 \\
\hline & all & 171 & 12 & 20 & 1.8 & 15.3 \\
\hline \multirow[t]{3}{*}{ verhmens } & male & 3 & 13 & 16 & 1.5 & 14.3 \\
\hline & female & 5 & 15 & 19 & 1.8 & 17.2 \\
\hline & all & 9 & 13 & 19 & 2.4 & 15.9 \\
\hline
\end{tabular}


Appendix 1.10. Number of lamellae under shortest toe.

\begin{tabular}{|c|c|c|c|c|c|c|}
\hline SPECIES & CATAGORY & $\mathbf{N}$ & MINIMUM & MAXIMUM & SD & MEAN \\
\hline \multirow[t]{3}{*}{ allochira } & male & 7 & 3 & 4 & 0.4 & 3.8 \\
\hline & female & 5 & 3 & 4 & 0.5 & 3.6 \\
\hline & all & 18 & 3 & 4 & 0.4 & 3.8 \\
\hline \multirow[t]{3}{*}{ amicorum } & male & 10 & 3 & 5 & 0.5 & 4 \\
\hline & female & 10 & 3 & 5 & 0.7 & 4.3 \\
\hline & all & 20 & 3 & 5 & 0.6 & 4.2 \\
\hline \multirow[t]{3}{*}{ clara } & male & 49 & 4 & 6 & 0.6 & 4.6 \\
\hline & female & 47 & 3 & 7 & 0.7 & 4.7 \\
\hline & all & 133 & 3 & 7 & 0.6 & 4.6 \\
\hline \multirow[t]{3}{*}{ haroldi } & male & 0 & & & & \\
\hline & female & 2 & 4 & 4 & 0 & 4 \\
\hline & all & 2 & 4 & 4 & 0 & 4 \\
\hline \multirow[t]{3}{*}{ jacksoni } & male & 14 & 4 & 5 & 0.5 & 4.3 \\
\hline & female & 16 & 3 & 5 & 0.6 & 4.2 \\
\hline & all & 38 & 3 & 5 & 0.5 & 4.3 \\
\hline \multirow[t]{3}{*}{ kingi } & male & 35 & 3 & 5 & 0.6 & 4.0 \\
\hline & female & 43 & 3 & 6 & 0.5 & 4.1 \\
\hline & all & 83 & 3 & 6 & 0.57 & 4.0 \\
\hline \multirow[t]{3}{*}{ micra } & male & 60 & 3 & 6 & 0.5 & 4.3 \\
\hline & female & 57 & 3 & 6 & 0.6 & 4.1 \\
\hline & all & 144 & 3 & 6 & 0.6 & 4.1 \\
\hline \multirow[t]{3}{*}{ muelleri } & male & 20 & 3 & 5 & 0.5 & 4.4 \\
\hline & female & 19 & 4 & 5 & 0.5 & 4.3 \\
\hline & all & 48 & 3 & 5 & 0.6 & 4.2 \\
\hline \multirow[t]{3}{*}{ nevinae } & male & 1 & 4 & 4 & 0 & 4 \\
\hline & female & 2 & 4 & 4 & 0 & 4 \\
\hline & all & 3 & 4 & 4 & 0 & 4 \\
\hline \multirow[t]{3}{*}{ occulta } & male & 5 & 4 & 4 & 0 & 4 \\
\hline & female & 2 & 4 & 4 & 0 & 4 \\
\hline & all & 15 & 3 & 4 & 0.3 & 3.8 \\
\hline \multirow[t]{3}{*}{ rhodonoides } & male & 117 & 3 & 6 & 0.6 & 4.3 \\
\hline & female & 96 & 3 & 6 & 0.6 & 4.3 \\
\hline & all & 226 & 3 & 6 & 0.6 & 4.3 \\
\hline \multirow[t]{3}{*}{ rolfei } & male & 64 & 3 & 6 & 0.7 & 4.5 \\
\hline & female & 86 & 3 & 6 & 0.6 & 4.6 \\
\hline & all & 169 & 3 & 6 & 0.7 & 4.5 \\
\hline \multirow[t]{3}{*}{ verhmens } & male & 3 & 4 & 6 & 1 & 5 \\
\hline & female & 4 & 5 & 6 & 0.5 & 5.3 \\
\hline & all & 8 & 4 & 6 & 0.7 & 5.0 \\
\hline
\end{tabular}


Appendix 1.11. Number of nuchals.

\begin{tabular}{|c|c|c|c|c|c|c|}
\hline SPECIES & CATAGORY & $\mathbf{N}$ & MINIMUM & MAXIMUM & SD & MEAN \\
\hline \multirow[t]{3}{*}{ allochira } & male & 7 & 4 & 6 & 0.7 & 5.1 \\
\hline & female & 8 & 2 & 6 & 1.3 & 4.7 \\
\hline & all & 20 & 2 & 6 & 1.0 & 4.8 \\
\hline \multirow[t]{3}{*}{ amicorum } & male & 10 & 2 & 6 & 1.3 & 4.9 \\
\hline & female & 2 & 4 & 6 & 1.4 & 4.9 \\
\hline & all & 12 & 2 & 6 & 1.2 & 4.9 \\
\hline \multirow[t]{3}{*}{ clara } & male & 53 & 0 & 8 & 1.2 & 4.9 \\
\hline & female & 42 & 2 & 9 & 1.2 & 4.9 \\
\hline & all & 155 & 0 & 9 & 1.2 & 4.8 \\
\hline \multirow[t]{3}{*}{ haroldi } & male & 0 & 3 & 8 & 0.9 & 6 \\
\hline & female & 2 & 4 & 5 & 0.7 & 4.5 \\
\hline & all & 3 & 2 & 5 & 1.5 & 3.7 \\
\hline \multirow[t]{3}{*}{ jacksoni } & male & 15 & 2 & 6 & 1.1 & 4.7 \\
\hline & female & 16 & 4 & 5 & 0.7 & 4.5 \\
\hline & all & 44 & 2 & 6 & 0.9 & 4.3 \\
\hline \multirow[t]{3}{*}{ kingi } & male & 69 & 3 & 6 & 1.1 & 6.0 \\
\hline & female & 54 & 3 & 9 & 1.0 & 6.2 \\
\hline & all & 148 & 3 & 9 & 0.9 & 6.0 \\
\hline \multirow[t]{3}{*}{ micra } & male & 115 & 0 & 8 & 1.1 & 4.9 \\
\hline & female & 97 & 0 & 7 & 1.3 & 4.7 \\
\hline & all & 334 & 0 & 8 & 1.2 & 4.8 \\
\hline \multirow[t]{3}{*}{ muelleri } & male & 25 & 4 & 7 & 0.8 & 5.2 \\
\hline & female & 23 & 2 & 8 & 1.4 & 5.2 \\
\hline & all & 62 & 2 & 8 & 1.1 & 5.2 \\
\hline \multirow[t]{3}{*}{ nevinae } & male & 1 & 4 & 4 & & 4 \\
\hline & female & 2 & 2 & 2 & & 2 \\
\hline & all & 3 & 2 & 4 & 1.1 & 2.7 \\
\hline \multirow[t]{3}{*}{ occulta } & male & 6 & 4 & 6 & 0.8 & 5.5 \\
\hline & female & 0 & & & & \\
\hline & all & 22 & 3 & 6 & 0.9 & 5.1 \\
\hline \multirow[t]{3}{*}{ rhodonoides } & male & 159 & 1 & 8 & 1.1 & 6 \\
\hline & female & 131 & 3 & 8 & 1.0 & 6.2 \\
\hline & all & 353 & 0 & 8 & 1.1 & 6.1 \\
\hline \multirow[t]{3}{*}{ rolfei } & male & 100 & 2 & 9 & 1.3 & 5.1 \\
\hline & female & 114 & 2 & 8 & 1.3 & 5.2 \\
\hline & all & 266 & 2 & 9 & 1.3 & 5.2 \\
\hline \multirow[t]{3}{*}{ verhmens } & male & 3 & 4 & 6 & 1.0 & 5 \\
\hline & female & 5 & 4 & 6 & 0.8 & 5.2 \\
\hline & all & 12 & 1 & 6 & 1.4 & 4.7 \\
\hline
\end{tabular}


Appendix 1.12 Number of paravertebrals.

\begin{tabular}{|c|c|c|c|c|c|c|}
\hline SPECIES & CATEGORY & $\mathbf{N}$ & MINIMUM & MAXIMUM & SD & MEAN \\
\hline \multirow[t]{3}{*}{ allochira } & male & 8 & 71 & 79 & 2.3 & 74.7 \\
\hline & female & 8 & 74 & 85 & 3.5 & 77.7 \\
\hline & all & 20 & 71 & 85 & 3.1 & 75.7 \\
\hline \multirow[t]{3}{*}{ amicorum } & male & 11 & 68 & 82 & 3.8 & 74.5 \\
\hline & female & 10 & 73 & 87 & 4.1 & 79.3 \\
\hline & all & 21 & 68 & 87 & 4.5 & 76.8 \\
\hline \multirow[t]{3}{*}{ clara } & male & 71 & 65 & 83 & & 73.1 \\
\hline & female & 52 & 66 & 83 & 3.8 & 76.0 \\
\hline & all & 170 & 65 & 83 & 4.6 & 74.1 \\
\hline \multirow[t]{3}{*}{ haroldi } & male & 1 & 69 & 69 & & 69.0 \\
\hline & female & 3 & 70 & 81 & 5.7 & 74.7 \\
\hline & all & 4 & 69 & 81 & 5.4 & 73.2 \\
\hline \multirow[t]{3}{*}{ jacksoni } & male & 15 & 69 & 85 & 5.2 & 76.7 \\
\hline & female & 17 & 72 & 89 & 6.0 & 81.4 \\
\hline & all & 39 & 69 & 89 & 5.8 & 79.2 \\
\hline \multirow[t]{3}{*}{ kingi } & male & 70 & 65 & 83 & 4.1 & 74.1 \\
\hline & female & 52 & 68 & 88 & 4.9 & 78.2 \\
\hline & all & 126 & 65 & 88 & 4.9 & 75.9 \\
\hline \multirow[t]{3}{*}{ micra } & male & 120 & 58 & 77 & 4.0 & 65.3 \\
\hline & female & 108 & 57 & 84 & 4.9 & 69.9 \\
\hline & all & 266 & 57 & 92 & 5.2 & 67.4 \\
\hline \multirow[t]{3}{*}{ muelleri } & male & 36 & 72 & 93 & 4.9 & 80.1 \\
\hline & female & 32 & 73 & 94 & 5.1 & 82.9 \\
\hline & all & 77 & 72 & 94 & 5.1 & 81.5 \\
\hline \multirow[t]{3}{*}{ nevinae } & male & 1 & 68 & 68 & & 68.0 \\
\hline & female & 2 & 69 & 70 & 0.7 & 69.5 \\
\hline & all & 3 & 68 & 70 & 1.0 & 69.0 \\
\hline \multirow[t]{3}{*}{ occulta } & male & 6 & 62 & 75 & 4.4 & 70.0 \\
\hline & female & 2 & 69 & 75 & 4.2 & 72.0 \\
\hline & all & 12 & 62 & 76 & 4.0 & 70.6 \\
\hline \multirow[t]{3}{*}{ rhodonoides } & male & 228 & 63 & 94 & 5.1 & 75.8 \\
\hline & female & 183 & 68 & 95 & 4.9 & 80.0 \\
\hline & all & 450 & 63 & 95 & 5.4 & 77.8 \\
\hline \multirow[t]{3}{*}{ rolfei } & male & 112 & 60 & 88 & 5.7 & 71.8 \\
\hline & female & 121 & 64 & 91 & 5.6 & 76.1 \\
\hline & all & 269 & 60 & 91 & 6.1 & 73.4 \\
\hline \multirow[t]{3}{*}{ verhmens } & male & 3 & 75 & 77 & 1.2 & 75.7 \\
\hline & female & 5 & 72 & 84 & 5.1 & 79.2 \\
\hline & all & 10 & 72 & 84 & 3.8 & 77.9 \\
\hline
\end{tabular}




\section{APPENDIX 2}

Allozyme profiles of all animals examined.

Specimens are listed in the same sequence as in Appendix 1. Code for loci:- $1=$ Acon2, $2=$ Acp, $3=$ Acyc, $4=$ Adh1, $5=$ Adh2, $6=A k, 7=C a, 8=$ Dia, $9=$ Enol, $10=$ Est, $11=$ Fdp, $12=$ Fum, $13=$ G6pd, 14 = Gda, $15=$ Glo, $16=$ Got1, $17=$ Got2, $18=$ Gpd, $19=$ Gpi, $20=$ Gsr, $21=$ Guk, $22=H b d h, 23=I d h, 24=L d h 1,25=L d h 3,26=M d h 1,27=M d h 2,28=M e, 29=$ $M p i, 30=N d p k, 31=P e p A, 32=P e p B, 33=P e p D, 34=P g a m, 35=6 P g d, 36=P g k, 37=P g m 1,38=P g m 2$, and $39=S r d h$. The following seven loci were invariant: Acon1, Alb, Lap, Ldh2, Np, Sod and Tpi.

\begin{tabular}{|c|c|c|c|c|c|c|c|c|c|c|c|c|c|c|c|c|c|c|c|}
\hline Species & RegNo & 1 & 2 & 3 & 4 & 5 & 6 & 7 & 8 & 9 & 10 & 11 & 12 & 13 & 14 & 15 & 16 & 17 & 18 \\
\hline clara & 116848 & $c$ & a & $\mathrm{d}$ & $\mathrm{b}$ & $\mathrm{ce}$ & c & $\mathrm{b}$ & $\mathrm{e}$ & $\mathrm{b}$ & $\mathrm{b}$ & $\mathrm{a}$ & a & $\mathrm{b}$ & $\mathrm{b}$ & $\mathrm{b}$ & $b$ & a & c \\
\hline clara & 129012 & $b$ & $\mathrm{a}$ & $\mathrm{d}$ & $\mathrm{b}$ & $\mathrm{e}$ & $c$ & $\mathrm{~b}$ & $\mathrm{f}$ & $\mathrm{b}$ & $\mathrm{b}$ & a & a & $b$ & $\mathrm{~b}$ & $\mathrm{~b}$ & $\mathrm{~b}$ & $\mathbf{a}$ & c \\
\hline clara & 139217 & $a b$ & $\mathrm{a}$ & $\mathrm{d}$ & b & $\mathrm{ae}$ & $c$ & $\mathrm{~b}$ & $\mathrm{e}$ & $\mathrm{b}$ & $\mathrm{b}$ & $\mathrm{a}$ & a & $\mathrm{b}$ & $b$ & $b$ & $\mathrm{~b}$ & a & c \\
\hline clara & 127508 & $\mathrm{~b}$ & $\mathrm{a}$ & $\mathrm{d}$ & b & de & $c$ & $b$ & ef & $\mathrm{b}$ & $\mathrm{b}$ & $a$ & a & $\mathrm{b}$ & $b$ & $\mathrm{~b}$ & $b$ & a & c \\
\hline clara & 135537 & $\mathrm{bd}$ & a & $\mathrm{d}$ & $\mathrm{b}$ & $\mathrm{e}$ & $\mathrm{c}$ & $\mathrm{b}$ & $\mathrm{e}$ & $\mathrm{b}$ & $\mathrm{b}$ & $\mathrm{a}$ & a & $\mathrm{b}$ & $\mathrm{b}$ & $\mathrm{b}$ & $\mathrm{b}$ & a & c \\
\hline clara & 140979 & $\mathrm{bc}$ & a & $\mathrm{d}$ & $\mathrm{b}$ & e & $\mathrm{c}$ & $\mathrm{b}$ & $\mathrm{e}$ & $\mathrm{b}$ & $\mathrm{b}$ & $\mathrm{a}$ & a & bc & $\mathrm{b}$ & $\mathrm{b}$ & $b$ & $\mathrm{a}$ & c \\
\hline clara & 141701 & $\mathrm{c}$ & a & $\mathrm{d}$ & $\mathrm{b}$ & $\mathrm{e}$ & $c$ & $b$ & $\mathrm{e}$ & $b$ & $b$ & $\mathrm{a}$ & a & $\mathrm{b}$ & $a b$ & b & $\mathrm{b}$ & a & c \\
\hline clara & 145198 & $\mathrm{~cd}$ & a & $\mathrm{df}$ & $\mathrm{b}$ & ce & $\mathrm{c}$ & $\mathrm{b}$ & $\mathrm{e}$ & $\mathrm{b}$ & $\mathrm{b}$ & a & $\mathrm{a}$ & $\mathrm{b}$ & $b$ & $\mathrm{~b}$ & $\mathrm{~b}$ & a & c \\
\hline clara & 116849 & $\mathrm{bc}$ & a & $\mathrm{d}$ & $b$ & $\mathrm{e}$ & c & $b$ & ef & $\mathrm{b}$ & $\mathrm{b}$ & $\mathrm{a}$ & $\mathrm{a}$ & $\mathrm{b}$ & $\mathrm{b}$ & $\mathrm{b}$ & $\mathrm{b}$ & $\mathrm{a}$ & c \\
\hline clara & 116851 & $\mathrm{bc}$ & $\mathrm{a}$ & $\mathrm{d}$ & $\mathrm{b}$ & $\mathrm{e}$ & c & $\mathfrak{b}$ & $\mathrm{e}$ & $\mathrm{b}$ & $b$ & $\mathrm{a}$ & $\mathrm{a}$ & $b$ & $\mathrm{~b}$ & $\mathrm{~b}$ & $\mathrm{~b}$ & a & c \\
\hline clara & 116567 & $c$ & a & $\mathrm{d}$ & $\mathrm{b}$ & ce & c & $b$ & $\mathrm{e}$ & $b$ & $b$ & $a$ & $\mathrm{a}$ & $\mathrm{b}$ & $b$ & $\mathrm{~b}$ & $\mathrm{~b}$ & a & c \\
\hline clara & 116565 & $\mathrm{c}$ & a & d & $b$ & de & c & $\mathrm{b}$ & e & b & $\mathrm{b}$ & a & $\mathrm{a}$ & $\mathrm{b}$ & $\mathrm{b}$ & $\mathrm{b}$ & $\mathrm{b}$ & $\mathrm{a}$ & c \\
\hline clara & 116564 & $\mathrm{~cd}$ & a & $d$ & $\mathrm{~b}$ & de & c & $\mathrm{b}$ & e & $\mathrm{b}$ & $\mathrm{b}$ & a & a & $\mathrm{b}$ & $a b$ & $\mathrm{~b}$ & $b$ & a & c \\
\hline clara & 116563 & $\mathrm{~cd}$ & a & $\mathrm{d}$ & $\mathrm{b}$ & $\mathrm{e}$ & c & $\mathrm{b}$ & $\mathrm{e}$ & $\mathrm{b}$ & $\mathrm{b}$ & a & a & $\mathrm{b}$ & $\mathrm{b}$ & $\mathrm{b}$ & $\mathrm{b}$ & a & $\mathrm{c}$ \\
\hline clara & 116852 & $\mathrm{bd}$ & $\mathrm{a}$ & $\mathrm{d}$ & $b$ & $\mathrm{e}$ & c & $b$ & ef & $\mathrm{b}$ & $b$ & a & a & $\mathrm{b}$ & $\mathrm{b}$ & $\mathrm{b}$ & $b$ & a & c \\
\hline clara & 116568 & $\mathrm{bc}$ & a & $\mathrm{d}$ & $\mathrm{b}$ & ce & $\mathrm{c}$ & $\mathrm{b}$ & $\mathrm{e}$ & $b$ & $b$ & $\mathrm{a}$ & a & be & $\mathrm{b}$ & $\mathrm{b}$ & $b$ & a & bc \\
\hline clara & 116569 & $\mathrm{~cd}$ & $\mathrm{a}$ & $d$ & $b$ & ef & c & $\mathrm{b}$ & $\mathrm{e}$ & $\mathrm{b}$ & $\mathrm{b}$ & $\mathrm{a}$ & a & $\mathrm{b}$ & $\mathrm{b}$ & $\mathrm{b}$ & $\mathrm{b}$ & $\mathrm{a}$ & c \\
\hline clara & 116570 & $\mathrm{bc}$ & a & $d$ & $b$ & $\mathrm{e}$ & c & b & e & $\mathrm{b}$ & $\mathrm{b}$ & $\mathrm{a}$ & a & $\mathrm{b}$ & $\mathrm{b}$ & $\mathrm{b}$ & $\mathrm{b}$ & a & c \\
\hline clara & 116694 & $\mathrm{~d}$ & a & $\mathrm{d}$ & $b$ & $\mathrm{e}$ & c & $\mathrm{b}$ & $\mathrm{h}$ & $\mathrm{b}$ & b & a & a & $\mathrm{b}$ & $b$ & $b$ & $\mathrm{~b}$ & $\mathrm{a}$ & c \\
\hline clara & 132577 & $\mathrm{bc}$ & $\mathrm{a}$ & $\mathrm{d}$ & $\mathrm{b}$ & e & c & $b$ & $\mathrm{e}$ & $b$ & $\mathbf{b}$ & $\mathrm{a}$ & a & $\mathrm{b}$ & b & $\mathrm{b}$ & $b$ & $\mathrm{a}$ & c \\
\hline clara & 132578 & $\mathrm{~b}$ & $\mathrm{a}$ & $\mathrm{d}$ & $\mathrm{b}$ & $\mathrm{e}$ & c & $\mathrm{b}$ & e & $b$ & $\mathrm{~b}$ & a & $\mathrm{a}$ & $\mathrm{b}$ & $\mathrm{b}$ & $\mathrm{b}$ & $\mathrm{b}$ & a & $c$ \\
\hline clara & 132579 & $\mathrm{~b}$ & $\mathrm{a}$ & $\mathrm{d}$ & $b$ & $\mathrm{e}$ & c & $b$ & $\mathrm{e}$ & $\mathrm{b}$ & $\mathrm{b}$ & a & a & $\mathrm{b}$ & $b$ & $b$ & $b$ & a & c \\
\hline clara & 114557 & $\mathrm{bd}$ & a & $\mathrm{d}$ & $b$ & $\mathrm{e}$ & c & $\mathrm{b}$ & e & $\mathrm{b}$ & $\mathrm{b}$ & $\mathrm{a}$ & $\mathrm{a}$ & $\mathrm{b}$ & $b$ & $\mathrm{~b}$ & $b$ & a & c \\
\hline clara & 114568 & $\mathrm{~cd}$ & a & $\mathrm{d}$ & $\mathrm{b}$ & $\mathrm{ce}$ & c & $\mathrm{b}$ & $\mathrm{e}$ & $\mathrm{b}$ & $b$ & $a$ & a & $\mathrm{b}$ & $\mathrm{b}$ & $\mathrm{b}$ & $\mathrm{b}$ & a & c \\
\hline clara & 114569 & $c$ & a & $\mathrm{d}$ & $\mathrm{b}$ & ce & c & $\mathrm{b}$ & $\mathrm{e}$ & $b$ & $\mathrm{~b}$ & $\mathrm{a}$ & a & $b$ & $\mathrm{~b}$ & $\mathrm{~b}$ & $\mathrm{~b}$ & $\mathrm{a}$ & c \\
\hline haroldi & 116652 & $\mathrm{~cd}$ & c & $\mathrm{cd}$ & $\mathrm{b}$ & e & c & $b$ & $\mathrm{e}$ & $b$ & $\mathrm{~b}$ & $\mathrm{a}$ & a & $\mathrm{b}$ & $\mathrm{b}$ & $a b$ & $\mathrm{~b}$ & a & C \\
\hline jacksoni & 104083 & $\mathrm{~d}$ & $\mathrm{a}$ & $\mathrm{d}$ & $\mathrm{b}$ & c & $\mathrm{a}$ & $\mathrm{b}$ & e & $\mathrm{b}$ & $\mathrm{b}$ & $\mathrm{a}$ & $\mathrm{a}$ & $\mathrm{d}$ & $a b$ & $\mathrm{~b}$ & $\mathrm{~b}$ & $\mathrm{a}$ & c \\
\hline jacksoni & 114904 & c & $\mathrm{a}$ & $\mathrm{d}$ & $b$ & c & $a$ & $\mathrm{~b}$ & c & $\mathrm{b}$ & $\mathrm{b}$ & $\mathrm{a}$ & a & $\mathrm{d}$ & $\mathrm{b}$ & $\mathrm{b}$ & $b$ & $\mathrm{a}$ & c \\
\hline jacksoni & 117283 & $\mathrm{c}$ & $\mathrm{a}$ & $\mathrm{d}$ & $b$ & c & $\mathrm{a}$ & $\mathrm{b}$ & e & $b$ & $b$ & $\mathrm{a}$ & a & de & $\mathrm{a}$ & $\mathrm{b}$ & $\mathrm{b}$ & a & C \\
\hline jacksoni & 114433 & c & $\mathrm{a}$ & $\mathrm{d}$ & $b$ & c & $\mathrm{a}$ & $\mathrm{b}$ & c & $\mathrm{b}$ & $\mathrm{b}$ & $a b$ & $\mathrm{a}$ & $\mathrm{d}$ & $a b$ & $\mathrm{~b}$ & $\mathrm{~b}$ & a & C \\
\hline jacksoni & 104134 & c & $\mathrm{a}$ & $\mathrm{d}$ & b & c & ac & $b$ & e & $\mathrm{b}$ & $\mathrm{b}$ & $\mathrm{a}$ & $\mathrm{a}$ & $\mathrm{d}$ & $\mathrm{b}$ & b & $\mathrm{b}$ & a & c \\
\hline jacksoni & 114543 & $\mathrm{c}$ & a & $\mathrm{d}$ & $b$ & c & $c$ & $\mathrm{~b}$ & e & $\mathrm{b}$ & $b$ & $\mathrm{a}$ & a & $\mathrm{d}$ & $b$ & $\mathrm{~b}$ & $\mathrm{~b}$ & $\mathrm{a}$ & \\
\hline jacksoni & 132608 & $\mathrm{~d}$ & a & de & $b$ & c & $\mathrm{ac}$ & $b$ & $\mathrm{e}$ & $\mathrm{b}$ & $b$ & $\mathbf{a}$ & a & $\mathrm{d}$ & $\mathrm{a}$ & $\mathrm{b}$ & $\mathrm{b}$ & a & \\
\hline jacksoni & 132609 & $\mathrm{~d}$ & $\mathrm{a}$ & $\mathrm{d}$ & $\mathrm{b}$ & $c$ & $\mathrm{ac}$ & $\mathrm{b}$ & ce & $\mathrm{b}$ & $\mathrm{b}$ & $\mathrm{ab}$ & $\mathrm{a}$ & $d$ & a & $\mathrm{b}$ & $\mathrm{b}$ & $\mathrm{a}$ & \\
\hline jacksoni & 132644 & $\mathrm{~d}$ & a & $\mathrm{de}$ & $\mathrm{b}$ & $\mathrm{c}$ & $\mathrm{a}$ & $\mathrm{b}$ & $\mathrm{e}$ & $\mathrm{b}$ & $b$ & $\mathrm{a}$ & $\mathrm{a}$ & $\mathrm{d}$ & a & $\mathrm{b}$ & $b$ & a & \\
\hline jacksoni & 132645 & $\mathrm{~d}$ & a & $\mathrm{e}$ & $\mathrm{b}$ & c & a & $b$ & e & $\mathrm{b}$ & $\mathrm{b}$ & a & a & $\mathrm{d}$ & a & $\mathrm{b}$ & $b$ & a & \\
\hline jacksoni & 132646 & $\mathrm{~d}$ & a & e & $\mathrm{b}$ & c & c & $b$ & e & $\mathrm{b}$ & $b$ & a & a & $\mathrm{d}$ & $\mathrm{a}$ & $\mathrm{b}$ & $\mathrm{b}$ & a & \\
\hline jacksoni & 132610 & $\mathrm{~d}$ & $\mathrm{a}$ & $\mathrm{d}$ & $\mathrm{b}$ & $\mathrm{c}$ & c & $\mathrm{b}$ & e & b & $\mathrm{b}$ & a & $\mathrm{a}$ & d & $\mathrm{a}$ & $\mathrm{b}$ & $\mathrm{b}$ & $\mathrm{a}$ & \\
\hline kingi & 117386 & $c$ & c & c & $\mathrm{c}$ & ce & c & $\mathrm{b}$ & $\mathrm{g}$ & $\mathrm{b}$ & $b$ & a & a & b & $a b$ & $\mathrm{~b}$ & $\mathrm{~b}$ & $\mathrm{a}$ & \\
\hline kingi & 144164 & $c$ & c & c & $\mathrm{b}$ & $\mathrm{c}$ & c & $b$ & $\mathrm{~g}$ & $a b$ & $\mathrm{~b}$ & a & $\mathrm{a}$ & $\mathrm{b}$ & $a$ & $\mathrm{~b}$ & b & $\mathrm{a}$ & \\
\hline kingi & 144165 & c & c & c & $\mathrm{c}$ & c & $c$ & $\mathrm{~b}$ & $\mathrm{~g}$ & $\mathrm{~b}$ & $\mathrm{~b}$ & a & $\mathrm{b}$ & $\mathrm{b}$ & $\mathrm{a}$ & $\mathrm{b}$ & $\mathrm{b}$ & a & \\
\hline kingi & 144713 & $\mathrm{~cd}$ & c & c & $\mathrm{cd}$ & c & C & $b$ & $\mathrm{~g}$ & $\mathrm{~b}$ & $b$ & a & $a b$ & $\mathrm{~b}$ & $a b$ & $\mathrm{~b}$ & $\mathrm{~b}$ & a & \\
\hline kingi & 141498 & $\mathrm{c}$ & c & c & $\mathrm{b}$ & $\mathrm{d}$ & c & $b$ & $\mathrm{~g}$ & $\mathrm{~b}$ & $a b$ & a & $\mathrm{b}$ & $\mathrm{b}$ & $a$ & $\mathrm{~b}$ & b & $\mathrm{a}$ & \\
\hline micra & 116738 & $\mathrm{~d}$ & $\mathrm{a}$ & c & $b$ & $\mathrm{c}$ & c & $b$ & $\mathrm{e}$ & $b c$ & $\mathrm{~b}$ & a & a & $\mathrm{b}$ & $\mathrm{b}$ & $\mathrm{b}$ & $\mathrm{b}$ & a & \\
\hline nicra & 116875 & $\mathrm{c}$ & $\mathrm{a}$ & $c$ & $\mathrm{~b}$ & ce & c & $\mathrm{b}$ & $\mathrm{d}$ & $b$ & $b$ & a & a & $\mathrm{b}$ & $\mathrm{b}$ & $\mathrm{b}$ & $\mathrm{b}$ & $\mathrm{a}$ & \\
\hline micra & 120376 & $\mathrm{C}$ & a & $\mathrm{d}$ & $b$ & c & c & $a b$ & $\mathrm{e}$ & $b$ & $b$ & $\mathrm{a}$ & $a$ & bc & $a b$ & $b$ & $b$ & $\mathrm{a}$ & \\
\hline micra & 120645 & c & $\mathrm{a}$ & $\mathrm{c}$ & $b$ & $\mathrm{c}$ & c & $a b$ & eg & $b$ & $\mathrm{~b}$ & ac & a & $\mathrm{b}$ & $\mathrm{b}$ & $\mathrm{b}$ & $b$ & a & \\
\hline micra & 120902 & $c$ & $\mathrm{a}$ & $\mathrm{cd}$ & $\mathrm{b}$ & ce & c & $\mathrm{b}$ & bg & $\mathrm{b}$ & $\mathrm{b}$ & $\mathrm{a}$ & a & $\mathrm{b}$ & $\mathrm{b}$ & $b$ & $b$ & $\mathrm{a}$ & \\
\hline micra & 122896 & $\mathrm{~cd}$ & a & ac & $\mathrm{b}$ & ae & c & $b$ & e & $b$ & b & a & a & bc & $\mathrm{bc}$ & $\mathrm{b}$ & $b$ & a & \\
\hline micra & 122876 & c & $\mathrm{a}$ & $\mathrm{df}$ & $\mathrm{b}$ & $\mathrm{e}$ & c & $\mathrm{b}$ & $\mathrm{e}$ & $\mathrm{b}$ & $b$ & a & a & $\mathrm{b}$ & $\mathrm{b}$ & $\mathrm{b}$ & $\mathrm{b}$ & a & \\
\hline micra & 116701 & $\mathrm{bc}$ & a & $c$ & $b$ & $\mathrm{e}$ & c & $\mathrm{b}$ & $\mathrm{c}$ & $\mathrm{b}$ & $\mathrm{b}$ & $a$ & a & $b$ & $\mathrm{~b}$ & $\mathrm{~b}$ & $b$ & a & \\
\hline micra & 116551 & $\mathrm{c}$ & $\mathrm{a}$ & $\mathrm{cd}$ & b & $\mathrm{ac}$ & $c$ & $\mathrm{~b}$ & $\mathrm{de}$ & $\mathrm{b}$ & $\mathrm{b}$ & $a$ & a & c & $\mathrm{b}$ & $\mathrm{b}$ & $\mathrm{b}$ & a & \\
\hline micra & 116552 & c & $\mathrm{a}$ & $\mathrm{cd}$ & $\mathrm{b}$ & $\mathrm{a}$ & c & $\mathrm{b}$ & eg & $b$ & $\mathrm{~b}$ & $\mathrm{a}$ & a & $\mathrm{b}$ & $\mathrm{b}$ & $\mathrm{b}$ & $\mathrm{b}$ & a & \\
\hline micra & 116553 & c & $\mathrm{a}$ & $\mathrm{cd}$ & $\mathrm{b}$ & a & c & $b$ & $\mathrm{e}$ & $b$ & $b$ & $\mathrm{a}$ & a & bc & $\mathrm{b}$ & $\mathrm{b}$ & $\mathrm{b}$ & a & \\
\hline micra & 116737 & de & $a b$ & $\mathrm{~cd}$ & $\mathrm{~b}$ & c & c & $b$ & eg & $b$ & $\mathrm{~b}$ & $\mathrm{a}$ & a & $\mathrm{b}$ & $\mathrm{b}$ & b & $\mathrm{b}$ & a & \\
\hline micra & 116575 & $c$ & $\mathrm{a}$ & $\mathrm{c}$ & $\mathrm{b}$ & c & c & $\mathrm{b}$ & e & $\mathrm{b}$ & $\mathrm{b}$ & a & a & bc & $\mathrm{b}$ & b & $b$ & a & \\
\hline micra & 116576 & c & $\mathrm{a}$ & $\mathrm{C}$ & $b$ & $\mathrm{C}$ & c & $\mathrm{b}$ & $\mathrm{e}$ & $\mathrm{b}$ & $\mathrm{b}$ & a & a & $\mathrm{b}$ & $\mathrm{b}$ & $\mathrm{b}$ & $\mathrm{b}$ & a & \\
\hline
\end{tabular}




\begin{tabular}{|c|c|c|c|c|c|c|c|c|c|c|c|c|c|c|c|c|c|c|c|c|}
\hline 19 & 20 & 21 & 22 & 23 & 24 & 25 & 26 & 27 & 28 & 29 & 30 & 31 & 32 & 33 & 34 & 35 & 36 & 37 & 38 & 39 \\
\hline be & c & $\mathrm{ad}$ & $\mathrm{d}$ & $a$ & a & a & $c$ & a & c & c & a & $\mathrm{d}$ & $\mathrm{cd}$ & fh & $a$ & $\mathrm{cf}$ & $b$ & a & $\mathrm{b}$ & ef \\
\hline $\mathrm{b}$ & c & $\mathrm{d}$ & bd & $\mathrm{a}$ & $a$ & a & $c$ & a & c & c & $\mathrm{a}$ & $\mathrm{bd}$ & $\mathrm{c}$ & hj & $a$ & $\mathrm{C}$ & $\mathrm{b}$ & a & $\mathrm{b}$ & c \\
\hline $\mathrm{e}$ & $\mathrm{C}$ & $\mathrm{d}$ & bd & $a$ & a & $\mathrm{a}$ & $c$ & $\mathrm{a}$ & $c$ & $\mathrm{C}$ & $a$ & $\mathrm{~d}$ & $\mathrm{~d}$ & $\mathrm{~h}$ & $\mathrm{a}$ & ac & $\mathrm{b}$ & $\mathrm{a}$ & $\mathrm{b}$ & $\mathrm{cd}$ \\
\hline be & ae & $\mathrm{d}$ & be & $\mathrm{a}$ & a & a & c & $a b$ & c & C & a & $\mathrm{d}$ & $\mathrm{d}$ & fh & $\mathrm{a}$ & $\mathrm{c}$ & $\mathrm{b}$ & $\mathrm{a}$ & $b$. & c \\
\hline $\mathrm{b}$ & $c$ & $\mathrm{~d}$ & $\mathrm{~d}$ & $\mathrm{a}$ & a & a & c & $\mathrm{a}$ & $c$ & c & a & de & $\mathrm{cd}$ & $\mathrm{h}$ & a & c & $b$ & a & $\mathrm{b}$ & $c$ \\
\hline be & c & $\mathrm{d}$ & $\mathrm{bd}$ & $\mathrm{a}$ & a & a & $c$ & a & $\mathrm{c}$ & c & a & $\mathrm{e}$ & $\mathrm{cd}$ & hj & a & $c$ & b & a & $b$ & $\mathrm{cf}$ \\
\hline $\mathrm{b}$ & c & $\mathrm{d}$ & $\mathrm{d}$ & a & a & $\mathrm{a}$ & c & a & $\mathrm{ce}$ & $c$ & $\mathrm{a}$ & $\mathrm{d}$ & $\mathrm{d}$ & $\mathrm{gh}$ & a & c & b & c & $b$ & $f$ \\
\hline $\mathrm{b}$ & c & $\mathrm{d}$ & $\mathrm{d}$ & a & a & a & c & $\mathrm{a}$ & $\mathrm{ce}$ & $c$ & $\mathrm{a}$ & $\mathrm{d}$ & $\mathrm{d}$ & $\mathrm{h}$ & a & c & $\mathrm{b}$ & $c$ & $\mathrm{~b}$ & ef \\
\hline $\mathrm{b}$ & c & $\mathrm{ad}$ & $\mathrm{d}$ & a & a & a & $c$ & $\mathrm{a}$ & $\mathrm{c}$ & c & $\mathrm{a}$ & $\mathrm{e}$ & $\mathrm{d}$ & gh & a & de & $\mathrm{b}$ & al & $b$ & ac \\
\hline $\mathrm{b}$ & c & $\mathrm{d}$ & $\mathrm{d}$ & $\mathrm{a}$ & $\mathrm{a}$ & a & c & $a b$ & c & $c$ & a & $\mathrm{bd}$ & cf & $h$ & $a$ & $\mathrm{e}$ & $\mathrm{b}$ & al & $\mathrm{b}$ & $\mathrm{c}$ \\
\hline $\mathrm{b}$ & c & $\mathrm{d}$ & $\mathrm{bd}$ & a & a & a & c & $\mathrm{a}$ & c & c & a & $\mathrm{d}$ & $\mathrm{cd}$ & $\mathrm{h}$ & a & $\mathrm{ce}$ & $\mathrm{b}$ & c & $\mathrm{b}$ & $\mathrm{f}$ \\
\hline$b$ & c & $\mathrm{d}$ & $\mathrm{d}$ & a & a & a & c & a & c & $\mathrm{c}$ & a & $\mathrm{d}$ & $\mathrm{d}$ & $\mathrm{h}$ & $\mathrm{a}$ & $c$ & $\mathrm{~b}$ & c & $\mathrm{b}$ & $\mathrm{df}$ \\
\hline $\mathrm{b}$ & $c$ & $\mathrm{~d}$ & $\mathrm{~d}$ & a & a & a & c & a & $c$ & $\mathrm{~cd}$ & $a$ & $\mathrm{~d}$ & $\mathrm{~d}$ & $\mathrm{~h}$ & $\mathrm{a}$ & $\mathrm{c}$ & $\mathrm{b}$ & c & $\mathrm{b}$ & $\mathrm{f}$ \\
\hline bd & $\mathrm{c}$ & $\mathrm{d}$ & $\mathrm{d}$ & a & a & a & c & a & $c$ & $c$ & a & $\mathrm{d}$ & $\mathrm{d}$ & fh & a & c & $\mathbf{b}$ & c & b & $f$ \\
\hline be & $\mathrm{cd}$ & $\mathrm{d}$ & $\mathrm{d}$ & a & a & $\mathrm{a}$ & c & $\mathrm{a}$ & $c$ & $\mathrm{c}$ & $a$ & $\mathrm{~d}$ & C & fh & a & c & $\mathrm{b}$ & $\mathrm{a}$ & b & c \\
\hline $\mathrm{b}$ & $\mathrm{C}$ & $\mathrm{d}$ & $\mathrm{b}$ & a & $\mathrm{a}$ & a & c & a & $b c$ & $\mathrm{~cd}$ & a & $\mathrm{d}$ & $\mathrm{d}$ & $\mathrm{h}$ & a & C & b & ce & b & $\mathrm{f}$ \\
\hline $\mathrm{b}$ & c & $\mathrm{d}$ & $\mathrm{d}$ & $a$ & a & a & c & $\mathrm{a}$ & be & c & a & $\mathrm{d}$ & $\mathrm{d}$ & fh & $\mathrm{a}$ & $c$ & b & $\mathrm{bc}$ & $b$ & $\mathrm{f}$ \\
\hline $\mathrm{b}$ & c & $\mathrm{d}$ & $\mathrm{d}$ & a & a & a & c & $\mathrm{a}$ & $\mathrm{e}$ & $c$ & a & $\mathrm{cd}$ & $\mathrm{d}$ & $\mathrm{h}$ & a & c & b & $c$ & $b$ & $\mathrm{cg}$ \\
\hline$a b$ & $c$ & $\mathrm{bd}$ & $b$ & a & $a$ & $a$ & c & $\mathrm{a}$ & $c$ & c & a & $\mathrm{d}$ & $\mathrm{d}$ & fh & $\mathrm{a}$ & c & b & 1 & b & C \\
\hline$b$ & c & $\mathrm{d}$ & $\mathrm{b}$ & a & $\mathrm{a}$ & a & c & $\mathrm{a}$ & $\mathrm{ce}$ & c & a & $\mathrm{d}$ & $\mathrm{d}$ & $\mathrm{h}$ & a & c & b & a & $b$ & $c$ \\
\hline $\mathrm{b}$ & c & $\mathrm{d}$ & $\mathrm{bd}$ & a & a & a & c & a & $\mathrm{C}$ & c & a & $\mathrm{d}$ & $\mathrm{d}$ & $\mathrm{h}$ & a & c & b & $\mathrm{a}$ & $\mathrm{b}$ & c \\
\hline b & c & $\mathrm{d}$ & $\mathrm{b}$ & a & $\mathrm{a}$ & a & c & a & $\mathrm{cd}$ & $c$ & a & $\mathrm{d}$ & $\mathrm{d}$ & $\mathrm{h}$ & a & C & b & a & b & $c$ \\
\hline $\mathrm{b}$ & C & $\mathrm{d}$ & $\mathrm{b}$ & a & a & a & $c$ & $\mathrm{a}$ & ce & c & a & $\mathrm{bd}$ & ce & $\mathrm{f}$ & a & $\mathrm{a}$ & $b$ & $\mathrm{a}$ & $\mathrm{b}$ & $\mathrm{cd}$ \\
\hline $\mathrm{b}$ & C & $d$ & bd & $\mathrm{a}$ & a & a & c & a & $c$ & c & $a$ & $\mathrm{~d}$ & $c$ & fh & a & $\mathrm{ac}$ & b & $\mathrm{a}$ & $b$ & $\mathrm{~cd}$ \\
\hline ef & c & $\mathrm{d}$ & $\mathrm{bd}$ & a & a & a & c & a & c & c & $\mathrm{a}$ & $\mathrm{d}$ & $\mathrm{c}$ & $\mathrm{h}$ & a & $\mathrm{a}$ & b & $\mathrm{a}$ & b & $\mathrm{cd}$ \\
\hline$c$ & C & c & $\mathrm{b}$ & a & a & b & c & $\mathrm{a}$ & c & c & a & $\mathrm{d}$ & $\mathrm{cd}$ & $\mathrm{f}$ & $\mathrm{a}$ & $c$ & $b$ & e & $b$ & C \\
\hline $\mathrm{e}$ & c & $\mathrm{d}$ & $\mathrm{b}$ & a & a & a & C & a & c & c & a & $\mathrm{b}$ & $\mathrm{d}$ & $\mathrm{h}$ & $\mathrm{a}$ & $\mathrm{e}$ & $b$ & $\mathrm{~d}$ & b & $c$ \\
\hline ef & c & $\mathrm{d}$ & $\mathrm{bd}$ & $a$ & a & a & c & a & $c$ & c & a & $\mathrm{b}$ & $\mathrm{d}$ & $h$ & $\mathbf{a}$ & $c$ & $\mathrm{~b}$ & $\mathrm{~d}$ & b & $c$ \\
\hline $\mathrm{e}$ & c & $\mathrm{d}$ & $\mathrm{bd}$ & a & a & a & c & a & C & c & $\mathrm{a}$ & $b$ & dh & $\mathrm{h}$ & $a b$ & ce & $\mathrm{b}$ & $\mathrm{d}$ & $b$ & $\mathrm{c}$ \\
\hline $\mathrm{e}$ & c & $\mathrm{d}$ & be & a & a & $\mathrm{a}$ & C & a & c & $c$ & a & b & $\mathrm{f}$ & $\mathrm{h}$ & $\mathrm{b}$ & $\mathrm{c}$ & $b$ & $\mathrm{~d}$ & b & $c$ \\
\hline $\mathrm{e}$ & c & $\mathrm{d}$ & $\mathrm{bd}$ & $\mathrm{a}$ & a & a & c & a & $c$ & $c$ & $\mathrm{a}$ & b & $\mathrm{bd}$ & $\mathrm{h}$ & $a$ & $\mathrm{e}$ & b & $\mathrm{d}$ & b & $c$ \\
\hline $\mathrm{e}$ & $c$ & $\mathrm{~d}$ & $\mathrm{bd}$ & $\mathrm{a}$ & a & a & c & $\mathrm{a}$ & $c$ & c & $a$ & $b$ & $\mathbf{f}$ & ch & $\mathrm{a}$ & e & b & $\mathrm{d}$ & b & $\mathrm{c}$ \\
\hline $\mathrm{e}$ & C & $\mathrm{d}$ & $\mathrm{d}$ & a & a & $a$ & c & a & $c$ & $c$ & $\mathrm{a}$ & $b$ & d & $h$ & $\mathrm{a}$ & $\mathrm{e}$ & b & $\mathrm{d}$ & $b$ & $c$ \\
\hline e & C & $\mathrm{d}$ & $\mathrm{d}$ & $\mathrm{a}$ & $\mathrm{a}$ & $\mathrm{a}$ & c & a & $\mathrm{bc}$ & $c$ & $\mathrm{a}$ & $b$ & $\mathrm{~d}$ & $\mathrm{~h}$ & a & ce & $b$ & $\mathrm{~d}$ & $\mathrm{~b}$ & c \\
\hline e & C & $\mathrm{d}$ & $d$ & a & a & a & c & a & $\mathrm{c}$ & C & a & $\mathrm{b}$ & $\mathrm{d}$ & $\mathrm{h}$ & $\mathrm{a}$ & ce & b & $\mathrm{d}$ & b & c \\
\hline $\mathrm{e}$ & c & d & $\mathrm{d}$ & $\mathrm{a}$ & a & a & C & a & c & $c$ & a & $\mathrm{b}$ & $\mathrm{d}$ & $\mathrm{h}$ & a & ce & $\mathrm{b}$ & d & $b$ & c \\
\hline e & ac & $\mathrm{d}$ & $\mathrm{d}$ & $\mathrm{a}$ & a & a & c & a & c & c & $\mathrm{a}$ & $b$ & $\mathrm{~d}$ & $\mathrm{~h}$ & a & c & $\mathrm{b}$ & d & b & c \\
\hline $\mathrm{e}$ & $\mathrm{c}$ & $\mathrm{d}$ & de & a & a & a & c & a & c & C & a & b & $\mathrm{d}$ & $\mathrm{h}$ & $\mathrm{a}$ & ce & $b$ & $\mathrm{~d}$ & b & c \\
\hline bc & $b c$ & $\mathrm{~d}$ & $\mathrm{~b}$ & a & a & $\mathrm{b}$ & $c$ & $\mathrm{a}$ & e & c & a & d & $\mathrm{d}$ & $\mathrm{f}$ & $\mathrm{a}$ & $\mathrm{d}$ & b & ce & $\mathrm{b}$ & $c$ \\
\hline bc & $c$ & $\mathrm{~d}$ & $a b$ & $\mathrm{a}$ & a & b & c & a & $\mathrm{d}$ & $c$ & a & $\mathrm{d}$ & $\mathrm{d}$ & $\mathrm{f}$ & a & $\mathrm{d}$ & b & ce & $b$ & c \\
\hline bc & $\mathrm{c}$ & $\mathrm{d}$ & $b$ & a & a & b & c & a & d & bc & $\mathrm{a}$ & $\mathrm{d}$ & bd & $\mathrm{f}$ & a & $\mathrm{d}$ & $b$ & $\mathrm{e}$ & $\mathrm{b}$ & c \\
\hline$c$ & c & $d$ & $\mathrm{~b}$ & a & $\mathrm{a}$ & b & c & a & $\mathrm{cd}$ & $b c$ & a & $\mathrm{d}$ & $\mathrm{d}$ & $\mathrm{f}$ & a & $\mathrm{d}$ & $b$ & e & b & $c$ \\
\hline c & c & $\mathrm{d}$ & $\mathrm{b}$ & a & $a$ & b & c & $\mathrm{a}$ & $\mathrm{cd}$ & $\mathrm{c}$ & a & $\mathrm{d}$ & $\mathrm{d}$ & $\mathrm{f}$ & a & $\mathrm{d}$ & b & c & $\mathrm{b}$ & c \\
\hline $\mathrm{b}$ & $\mathrm{d}$ & bd & $b$ & a & a & $\mathrm{a}$ & c & a & $\mathrm{c}$ & c & $a$ & $\mathrm{bd}$ & $\mathrm{d}$ & fh & a & $\mathrm{d}$ & b & $\mathrm{k}$ & $b$ & c \\
\hline bf & c & $\mathrm{d}$ & b & a & $\mathrm{a}$ & b & c & a & bc & $c$ & a & $\mathrm{bd}$ & $\mathrm{d}$ & $\mathrm{dg}$ & a & ce & $b$ & eg & $a b$ & a \\
\hline$b$ & $\mathrm{~cd}$ & $\mathrm{~d}$ & $\mathrm{~b}$ & a & a & a & c & a & $\mathrm{cd}$ & c & a & $\mathrm{d}$ & $\mathrm{cf}$ & $\mathrm{df}$ & a & $\mathrm{e}$ & $b$ & $\mathrm{~g}$ & $\mathrm{~b}$ & $c$ \\
\hline b & $\mathrm{cd}$ & $\mathrm{d}$ & $b$ & a & a & a & c & a & be & c & a & $\mathrm{d}$ & ce & $\mathrm{g}$ & a & $\mathrm{e}$ & b & $\mathrm{cg}$ & $b$ & ac \\
\hline b & $\mathrm{d}$ & $d$ & $\mathrm{~b}$ & a & a & a & c & a & $c$ & c & a & de & $\mathrm{d}$ & $\mathrm{dg}$ & $\mathrm{a}$ & $\mathrm{e}$ & b & eg & $\mathrm{b}$ & $\mathrm{ac}$ \\
\hline b & $c d$ & $\mathrm{~d}$ & $\mathrm{~b}$ & a & a & a & c & a & bc & $c$ & a & $\mathrm{d}$ & $\mathrm{cd}$ & $\mathrm{g}$ & $\mathrm{a}$ & $\mathrm{e}$ & $\mathrm{b}$ & $\mathrm{cg}$ & $b$ & ac \\
\hline b & $\mathrm{c}$ & $\mathrm{d}$ & b & a & a & a & c & a & c & c & $a$ & $\mathrm{~d}$ & $\mathrm{dg}$ & $\mathrm{dg}$ & a & $\mathrm{de}$ & $\mathrm{b}$ & eg & $b$ & $\mathrm{ac}$ \\
\hline b & c & $\mathrm{d}$ & b & a & $\mathrm{a}$ & b & c & a & $c$ & c & $\mathrm{a}$ & b & $\mathrm{d}$ & $\mathrm{ad}$ & $a$ & $\mathrm{ce}$ & $b$ & $\mathrm{i}$ & b & $\mathrm{ac}$ \\
\hline b & ce & $\mathrm{d}$ & b & $\mathrm{a}$ & a & a & c & a & be & c & $\mathrm{a}$ & $\mathrm{d}$ & $c d$ & $\mathrm{~d}$ & a & $\mathrm{e}$ & $b$ & $\mathrm{fg}$ & $\mathrm{b}$ & $\mathrm{c}$ \\
\hline b & c & $\mathrm{d}$ & b & a & $\mathrm{a}$ & a & c & a & c & c & a & $d$ & $\mathrm{~d}$ & $\mathrm{~d}$ & a & $\mathrm{e}$ & $b$ & eg & $b$ & $\mathrm{ac}$ \\
\hline b & c & $\mathrm{d}$ & $b$ & a & a & a & c & $a$ & $\mathrm{ce}$ & $c$ & a & $\mathrm{d}$ & $\mathrm{cd}$ & $\mathrm{d}$ & $\mathrm{a}$ & e & $b$ & $\mathrm{~g}$ & b & ac \\
\hline b & $\mathrm{e}$ & $\mathrm{b}$ & b & $a$ & a & a & c & $\mathrm{a}$ & $c$ & $\mathrm{~cd}$ & a & $\mathrm{d}$ & $\mathrm{d}$ & $\mathrm{h}$ & $a$ & $c$ & $b$ & $\mathrm{k}$ & $b$ & $c$ \\
\hline b & e & $\mathrm{bd}$ & b & a & a & a & c & a & ce & $c$ & a & $\mathrm{d}$ & $\mathrm{d}$ & $\mathrm{g}$ & $\mathrm{a}$ & $\mathrm{ce}$ & b & $\mathrm{e}$ & b & ac \\
\hline b & e & $\mathrm{d}$ & $b$ & a & a & $a$ & c & a & $\mathrm{e}$ & c & $a$ & $\mathrm{~d}$ & $\mathrm{~d}$ & $\mathrm{fg}$ & a & $\mathrm{e}$ & b & ei & $\mathrm{b}$ & $\mathrm{c}$ \\
\hline
\end{tabular}


Appendix 2 (cont.)

\begin{tabular}{|c|c|c|c|c|c|c|c|c|c|c|c|c|c|c|c|c|c|c|c|}
\hline Species & RegNo & 1 & 2 & 3 & 4 & 5 & 6 & 7 & 8 & 9 & 10 & 11 & 12 & 13 & 14 & 15 & 16 & 17 & 18 \\
\hline micra & 116577 & $b$ & a & c & $b$ & c & c & b & $\mathrm{e}$ & $\mathrm{b}$ & $\mathrm{b}$ & a & a & $b$ & $\mathrm{~b}$ & $b$ & $b$ & $\mathrm{a}$ & c \\
\hline micra & 116583 & $\mathrm{c}$ & $\mathrm{a}$ & $\mathrm{c}$ & b & c & c & b & eg & $\mathrm{b}$ & $a b$ & $\mathrm{a}$ & $\mathrm{a}$ & $b$ & $\mathrm{~b}$ & $\mathrm{~b}$ & $\mathrm{~b}$ & a & c \\
\hline micra & 116584 & bc & a & $\mathrm{C}$ & $\mathrm{b}$ & $\mathrm{e}$ & $\mathrm{c}$ & $\mathrm{b}$ & $\mathrm{e}$ & $\mathrm{b}$ & $\mathrm{b}$ & a & $\mathrm{a}$ & $b$ & be & $\mathrm{b}$ & $\mathrm{b}$ & a & $\mathrm{c}$ \\
\hline micra & 116585 & bd & a & $c$ & $\mathrm{~b}$ & $\mathrm{ce}$ & $\mathrm{C}$ & b & $\mathrm{ce}$ & $b$ & $\mathrm{~b}$ & $\mathrm{a}$ & a & $\mathrm{bc}$ & $\mathrm{b}$ & $\mathrm{b}$ & $\mathrm{b}$ & a & c \\
\hline micra & 116747 & $\mathrm{~cd}$ & a & $c$ & $\mathrm{~b}$ & $\mathrm{e}$ & $\mathrm{C}$ & $\mathrm{b}$ & de & $\mathrm{b}$ & $b$ & a & $\mathrm{a}$ & $a b$ & $\mathrm{~b}$ & $\mathrm{~b}$ & $\mathrm{~b}$ & a & c \\
\hline micra & 116748 & $\mathrm{c}$ & a & $c$ & $\mathrm{~b}$ & $d f$ & $\mathrm{C}$ & $b$ & $\mathrm{e}$ & $\mathrm{b}$ & $\mathrm{b}$ & a & ac & $b$ & $\mathrm{~b}$ & $\mathrm{~b}$ & $\mathrm{~b}$ & $\mathrm{a}$ & $\mathrm{c}$ \\
\hline micra & 116786 & $\mathrm{~cd}$ & a & $c$ & - & ef & - & b & $\mathrm{g}$ & $\mathrm{b}$ & $\mathrm{b}$ & - & $\mathrm{a}$ & $\mathrm{b}$ & - & $\mathbf{b}$ & $\mathrm{b}$ & $\mathrm{a}$ & c \\
\hline micra & 115233 & ce & a & bc & $\mathrm{b}$ & ce & $\mathrm{c}$ & b & $\mathrm{e}$ & $\mathrm{b}$ & $\mathrm{b}$ & a & a & $\mathrm{b}$ & $b$ & $\mathrm{~b}$ & $\mathrm{~b}$ & $\mathrm{a}$ & c \\
\hline micra & 116582 & $\mathrm{~cd}$ & a & $c$ & $b$ & ce & $c$ & a & $\mathrm{e}$ & $\mathrm{b}$ & $\mathrm{b}$ & a & a & $\mathrm{b}$ & $\mathrm{b}$ & $\mathrm{b}$ & $\mathrm{b}$ & a & c \\
\hline muelleri & 114325 & bc & $\mathrm{a}$ & $\mathrm{d}$ & $\mathrm{b}$ & $\mathrm{c}$ & c & $b$ & c & $\mathrm{b}$ & $b$ & $\mathrm{a}$ & a & $\mathrm{d}$ & bd & $\mathrm{b}$ & $\mathrm{b}$ & a & c \\
\hline muelleri & 141298 & $b c$ & a & $d f$ & $b$ & c & c & $\mathrm{b}$ & e & $b$ & $b$ & a & a & $\mathrm{d}$ & $\mathrm{bd}$ & $b$ & $\mathrm{~b}$ & a & c \\
\hline muelleri & 141357 & $b c$ & a & $\mathrm{d}$ & $\mathrm{b}$ & c & c & $\mathrm{b}$ & $\mathrm{e}$ & $b$ & $\mathrm{~b}$ & a & $\mathrm{a}$ & $\mathrm{d}$ & $\mathrm{b}$ & $b$ & $b$ & $\mathrm{a}$ & $\mathrm{c}$ \\
\hline muelleri & 102236 & $\mathrm{~b}$ & a & $\mathrm{d}$ & $\mathrm{b}$ & c & c & $\mathrm{b}$ & e & $\mathrm{b}$ & $\mathrm{b}$ & a & $\mathrm{a}$ & $\mathrm{d}$ & de & $\mathrm{b}$ & $b$ & a & c \\
\hline muelleri & 102237 & bc & a & $\mathrm{d}$ & $\mathrm{b}$ & c & $\mathrm{c}$ & $\mathrm{b}$ & eg & $\mathrm{b}$ & $\mathrm{b}$ & a & a & $\mathrm{d}$ & $\mathrm{bd}$ & $\mathrm{b}$ & $\mathrm{b}$ & a & $c$ \\
\hline muelleri & 102238 & bc & a & $\mathrm{d}$ & $\mathrm{b}$ & c & - & $\mathrm{b}$ & $\mathrm{e}$ & $\mathrm{b}$ & $\mathrm{b}$ & a & a & $\mathrm{d}$ & $\mathrm{d}$ & $\mathrm{b}$ & $b$ & a & C \\
\hline muelleri & 108827 & bc & $\mathrm{a}$ & df & $\mathrm{b}$ & c & - & $\mathrm{b}$ & e & $b$ & $\mathrm{~b}$ & a & a & $\mathrm{d}$ & $\mathrm{b}$ & $\mathrm{b}$ & $\mathrm{bd}$ & a & c \\
\hline nevinae & 135295 & $c$ & a & $c$ & $\mathrm{a}$ & c & bc & $\mathrm{b}$ & $\mathrm{f}$ & $\mathrm{b}$ & $\mathrm{b}$ & a & a & $\mathrm{d}$ & $\mathrm{b}$ & $\mathrm{b}$ & $\mathrm{b}$ & a & c \\
\hline nevinae & 135306 & c & a & c & $\mathrm{a}$ & c & $\mathrm{bc}$ & b & $f$ & $\mathrm{~b}$ & $\mathrm{~b}$ & a & a & $\mathrm{d}$ & $\mathrm{b}$ & $\mathrm{b}$ & $\mathrm{b}$ & a & c \\
\hline occulta & 120526 & c & $\mathrm{a}$ & $\mathrm{d}$ & $\mathrm{b}$ & e & $c$ & $\mathrm{~b}$ & $\mathrm{~g}$ & $\mathrm{~b}$ & $b$ & a & c & $\mathrm{b}$ & c & $\mathrm{b}$ & $\mathrm{b}$ & a & c \\
\hline occulta & 123296 & d & a & $d$ & $\mathrm{~b}$ & $\mathrm{e}$ & c & $\mathrm{b}$ & $\mathrm{g}$ & $b$ & $\mathrm{~b}$ & a & c & $\mathrm{b}$ & c & $\mathrm{b}$ & $\mathrm{b}$ & a & c \\
\hline rhodonoides & 116756 & c & a & $b$ & $\mathrm{~b}$ & c & c & $\mathrm{b}$ & eg & $\mathrm{b}$ & $\mathrm{a}$ & a & a & $\mathrm{b}$ & b & $\mathrm{b}$ & bd & a & c \\
\hline rhodonoides & 116755 & c & $\mathrm{a}$ & $b$ & $\mathrm{~b}$ & $\mathrm{c}$ & $\mathrm{c}$ & $\mathbf{b}$ & e & $\mathrm{b}$ & $\mathrm{a}$ & a & a & $b$ & $\mathrm{~b}$ & $\mathrm{~b}$ & $\mathrm{~b}$ & a & c \\
\hline rhodonoides & 116754 & c & $\mathrm{a}$ & $\mathrm{b}$ & $\mathrm{b}$ & c & c & $b$ & bg & $\mathrm{b}$ & $\mathrm{a}$ & a & a & $\mathrm{b}$ & $\mathrm{b}$ & $\mathrm{b}$ & $b$ & $\mathrm{a}$ & $\mathrm{c}$ \\
\hline rhodonoides & 116287 & c & a & $\mathrm{d}$ & $\mathrm{b}$ & c & c & $\mathrm{b}$ & $\mathrm{g}$ & $\mathrm{b}$ & b & a & a & $\mathrm{b}$ & $a b$ & $\mathrm{~b}$ & $b$ & a & ac \\
\hline rhodonoides & 116288 & c & a & $\mathrm{d}$ & $\mathrm{c}$ & $\mathrm{c}$ & c & $\mathrm{b}$ & $\mathrm{g}$ & $\mathrm{b}$ & $\mathrm{b}$ & a & a & $b$ & $a b$ & $\mathrm{~b}$ & $\mathrm{~b}$ & a & ac \\
\hline rhodonoides & 116289 & $c$ & a & $\mathrm{d}$ & $\mathrm{b}$ & $\mathrm{c}$ & c & $\mathrm{b}$ & $\mathrm{g}$ & $b$ & $\mathrm{~b}$ & a & $\mathrm{a}$ & $b$ & $a b$ & $\mathrm{~b}$ & $\mathrm{~b}$ & a & $\mathrm{C}$ \\
\hline rhodonoides & 144706 & $\mathrm{bc}$ & a & $\mathrm{d}$ & c & $\mathrm{cd}$ & c & $\mathrm{b}$ & $\mathrm{g}$ & $b$ & $\mathrm{~b}$ & a & $a b$ & $\mathrm{~b}$ & $\mathrm{~b}$ & $\mathrm{~b}$ & $\mathrm{~b}$ & a & c \\
\hline rhodonoides & 144717 & bc & a & $\mathrm{d}$ & $b$ & $\mathrm{C}$ & C & $\mathrm{b}$ & $\mathrm{g}$ & $\mathrm{b}$ & $\mathrm{b}$ & & a & $\mathrm{b}$ & b & $\mathrm{b}$ & $\mathrm{b}$ & a & c \\
\hline rhodonoides & 144555 & $\mathrm{bc}$ & a & $\mathrm{d}$ & $b$ & $\mathrm{~cd}$ & c & $\mathrm{b}$ & $\mathrm{g}$ & $\mathrm{b}$ & $\mathrm{b}$ & & $a$ & $b$ & $\mathrm{~b}$ & $\mathrm{~b}$ & $\mathrm{~b}$ & a & c \\
\hline rhodonoides & 117375 & $\mathrm{c}$ & a & $\mathrm{d}$ & $\mathrm{b}$ & $\mathrm{c}$ & c & $\mathrm{b}$ & g & $\mathrm{b}$ & $\mathrm{b}$ & $\mathrm{a}$ & $a b$ & $\mathrm{~b}$ & $\mathrm{~b}$ & $\mathrm{~b}$ & $\mathrm{~b}$ & a & c \\
\hline rhodonoides & 117284 & c & a & $b$ & $\mathrm{~b}$ & ce & c & $\mathrm{b}$ & $\mathrm{g}$ & $\mathrm{b}$ & $\mathrm{b}$ & a & $\mathrm{a}$ & $\mathrm{b}$ & $\mathrm{b}$ & $b$ & $\mathrm{~b}$ & a & c \\
\hline lodonoi & 144545 & bc & a & $\mathrm{d}$ & $\mathrm{b}$ & $c$ & c & $\mathrm{b}$ & $\mathrm{g}$ & $\mathrm{b}$ & $\mathrm{b}$ & a & a & $\mathrm{b}$ & $\mathrm{b}$ & $\mathrm{b}$ & $\mathrm{b}$ & $\mathrm{a}$ & c \\
\hline odonoides & 144566 & $\mathrm{c}$ & $a$ & $\mathrm{~d}$ & $\mathrm{~b}$ & c & $\mathrm{c}$ & $\mathrm{b}$ & $g$ & $\mathrm{~b}$ & $\mathrm{~b}$ & a & a & $\mathrm{b}$ & $\mathrm{b}$ & $\mathrm{b}$ & $\mathrm{b}$ & $\mathrm{a}$ & c \\
\hline odonoides & 144554 & $b$ & a & $\mathrm{d}$ & $\mathrm{b}$ & c & $\mathrm{c}$ & $\mathrm{b}$ & $\mathrm{g}$ & $b$ & $\mathrm{~b}$ & a & a & $\mathrm{b}$ & $\mathrm{b}$ & $b$ & $\mathrm{~b}$ & $\mathrm{a}$ & $\mathrm{C}$ \\
\hline odonoides & 126590 & $\mathrm{c}$ & $\mathrm{a}$ & $\mathrm{d}$ & $b$ & c & c & $\mathrm{b}$ & $\mathrm{g}$ & $b$ & $\mathrm{~b}$ & a & a & $\mathrm{b}$ & $\mathrm{b}$ & $b$ & bc & $\mathrm{a}$ & c \\
\hline donoides & 126591 & c & a & $\mathrm{d}$ & $\mathrm{b}$ & c & $\mathrm{c}$ & $\mathrm{b}$ & g & $\mathrm{b}$ & $\mathrm{b}$ & & & $\mathrm{b}$ & $\mathrm{b}$ & & $\mathrm{b}$ & $a b$ & c \\
\hline odonoides & 117376 & $\mathrm{c}$ & a & $\mathrm{d}$ & $\mathrm{b}$ & c & c & $b$ & g & $\mathrm{b}$ & 1 & & & $\mathrm{~b}$ & $\mathrm{~b}$ & & $\mathrm{~b}$ & $\mathrm{a}$ & c \\
\hline odonoides & 145076 & $\mathrm{bc}$ & a & $c$ & $\mathrm{~b}$ & c & c & $\mathrm{b}$ & eg & $\tilde{b}$ & $b$ & $\mathrm{a}$ & & $\mathrm{bc}$ & $\mathrm{b}$ & & bd & $a b$ & c \\
\hline hodonoides & 145071 & $\mathrm{~b}$ & $\mathrm{a}$ & $\mathrm{c}$ & $\mathrm{b}$ & $\mathrm{c}$ & c & $\mathrm{b}$ & eg & $\mathrm{b}$ & $\mathrm{b}$ & a & $\mathrm{a}$ & $\mathrm{bd}$ & $\mathrm{b}$ & $\mathrm{b}$ & $\mathrm{b}$ & $a b$ & c \\
\hline donoides & SA51526 & c & a & $\mathrm{bc}$ & $\mathrm{b}$ & c & c & $\mathrm{b}$ & $\mathrm{g}$ & $\mathrm{b}$ & $\mathrm{b}$ & a & a & $\mathrm{b}$ & $b$ & $\mathrm{~b}$ & $\mathrm{~b}$ & $\mathrm{a}$ & c \\
\hline rhodonoides & SA51517 & $c$ & $\mathrm{a}$ & $\mathrm{bd}$ & $\mathrm{b}$ & c & c & bc & $\mathrm{g}$ & $\mathrm{b}$ & $\mathrm{b}$ & a & a & $\mathrm{b}$ & $\mathrm{a}$ & $\mathrm{b}$ & $\mathrm{b}$ & a & \\
\hline rhodonoides & SA54644 & $\mathrm{bc}$ & a & $\mathrm{d}$ & $\mathrm{b}$ & $\mathrm{c}$ & c & $\mathrm{b}$ & $\mathrm{g}$ & $\mathrm{b}$ & $\mathrm{b}$ & a & $a$ & $\mathrm{~b}$ & a & $\mathrm{b}$ & $\mathrm{b}$ & a & \\
\hline odonoides & SA41308 & $c$ & a & de & - & c & - & $\mathrm{b}$ & $\mathrm{g}$ & $\mathrm{b}$ & $\mathrm{b}$ & $\mathrm{a}$ & a & $a b$ & $a$ & $b$ & $\mathrm{bd}$ & a & \\
\hline donoides & SA54589 & $\mathrm{c}$ & a & $\mathrm{d}$ & $\mathrm{c}$ & $\mathrm{d}$ & c & - & $\begin{array}{l}8 \\
\mathrm{~g}\end{array}$ & $\mathrm{~b}$ & 1 & 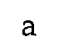 & & $a b$ & a & $\mathrm{b}$ & $\mathrm{b}$ & a & \\
\hline lodonoides & SA45515 & $c$ & $\mathrm{a}$ & $\mathrm{d}$ & bd & $\mathrm{cd}$ & c & $\mathrm{b}$ & $\mathrm{g}$ & $\mathrm{b}$ & 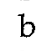 & $a$ & & $\mathrm{a}$ & & $b$ & $\mathrm{~b}$ & a & \\
\hline donoides & SA38233 & $\mathrm{bc}$ & a & c & $\mathrm{b}$ & $\mathrm{c}$ & c & $\mathrm{b}$ & g & $\mathrm{b}$ & $\mathrm{b}$ & a & $a$ & $\mathrm{~b}$ & $\mathrm{a}$ & b & $\mathrm{b}$ & a & \\
\hline lfei & 116695 & $\mathrm{bd}$ & a & $\mathrm{d}$ & $b$ & $\mathrm{e}$ & c & $\mathrm{b}$ & g & $\mathrm{b}$ & $\mathrm{b}$ & $\mathrm{a}$ & $\mathrm{a}$ & $\mathrm{b}$ & $\mathrm{b}$ & $b$ & $b$ & a & c \\
\hline Ifei & 116742 & $b c$ & a & $\mathrm{cd}$ & b & ce & c & $\mathrm{b}$ & $\mathrm{g}$ & bc & $\mathrm{b}$ & $\mathrm{a}$ & a & $\mathrm{b}$ & $b$ & $\mathrm{~b}$ & $b$ & $\mathrm{a}$ & c \\
\hline fei & 116743 & $\mathrm{~cd}$ & a & $\mathrm{cd}$ & $b$ & $\mathrm{e}$ & c & $\mathrm{b}$ & $\mathrm{g}$ & $\mathrm{b}$ & $\mathrm{b}$ & $a$ & a & $b$ & b & $\mathrm{b}$ & $\mathrm{b}$ & $\mathrm{a}$ & \\
\hline & 117121 & c & c & $\mathrm{d}$ & $\mathrm{b}$ & e & c & b & ae & $\mathrm{b}$ & $\mathrm{b}$ & c & $\mathrm{a}$ & $\mathrm{b}$ & $\mathrm{b}$ & $\mathrm{b}$ & $b$ & a & \\
\hline rolfei & 120541 & C & a & $\mathrm{cd}$ & $\mathrm{b}$ & $\mathrm{ce}$ & c & $\mathrm{b}$ & $\mathrm{g}$ & $b$ & 1 & $\mathrm{a}$ & $\mathrm{a}$ & $\mathrm{b}$ & $\mathrm{b}$ & $\mathrm{b}$ & $\mathrm{b}$ & a & \\
\hline rolfei & 120557 & $c$ & $\mathrm{a}$ & $c$ & $b$ & ce & c & $\mathrm{b}$ & $\begin{array}{l}0 \\
\mathrm{~g}\end{array}$ & $\mathrm{~b}$ & $b$ & a & a & $b$ & $b$ & $b$ & $a b$ & a & \\
\hline Iffei & 120575 & $\mathrm{c}$ & $\mathrm{a}$ & $\mathrm{cd}$ & $\mathrm{b}$ & $\mathrm{e}$ & c & b & $\mathrm{g}$ & $b$ & $\mathrm{~b}$ & a & & $\mathrm{b}$ & $\mathrm{b}$ & $\mathrm{b}$ & $\mathrm{b}$ & a & \\
\hline Ifei & 124935 & $\mathrm{~cd}$ & a & $\mathrm{cd}$ & b & ce & c & $\mathrm{b}$ & $\mathrm{g}$ & $\mathrm{b}$ & b & a & 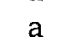 & $\mathrm{b}$ & $\mathrm{b}$ & $\mathrm{b}$ & $\mathrm{b}$ & a & \\
\hline & 123797 & $c$ & a & $\mathrm{d}$ & $b$ & $\mathrm{c}$ & c & $\mathrm{b}$ & $\mathrm{g}$ & $\mathrm{b}$ & $\mathrm{b}$ & ac & a & $\mathrm{b}$ & $\mathrm{b}$ & $b$ & $\mathrm{~b}$ & $\mathrm{a}$ & \\
\hline verhmens & 141369 & c & $\mathrm{a}$ & $c$ & $b$ & c & c & $\mathrm{b}$ & g & $\mathrm{b}$ & $b$ & $\mathrm{a}$ & a & $\mathrm{b}$ & - & $b$ & $\mathrm{~b}$ & $\mathrm{a}$ & \\
\hline verhmens & 139315 & c & a & $\mathrm{ac}$ & $\mathrm{b}$ & be & c & $b$ & $\mathrm{~g}$ & $\mathrm{~b}$ & $\mathrm{~b}$ & a & $\mathrm{a}$ & $b$ & $\mathrm{~b}$ & $\mathrm{~b}$ & $\mathrm{~b}$ & $\mathrm{a}$ & \\
\hline
\end{tabular}




\begin{tabular}{|c|c|c|c|c|c|c|c|c|c|c|c|c|c|c|c|c|c|c|c|c|}
\hline 19 & 20 & 21 & 22 & 23 & 24 & 25 & 26 & 27 & 28 & 29 & 30 & 31 & 32 & 33 & 34 & 35 & 36 & 37 & 38 & 39 \\
\hline$b$ & c & d & $\mathrm{b}$ & a & a & a & c & a & c & c & a & $\mathrm{d}$ & $\mathrm{d}$ & fh & a & e & $b$ & gi & $\mathrm{b}$ & $\mathrm{a}$ \\
\hline $\mathrm{b}$ & $\mathrm{e}$ & d & $\mathrm{b}$ & $\mathrm{a}$ & a & a & $c$ & $\mathrm{a}$ & c & c & a & $\mathrm{bd}$ & $\mathrm{d}$ & $\mathrm{df}$ & $\mathrm{a}$ & $\mathrm{e}$ & $\mathrm{b}$ & $\mathrm{cg}$ & $\mathrm{b}$ & $\mathrm{ac}$ \\
\hline$b$ & $\mathrm{~cd}$ & $\mathrm{~d}$ & $\mathrm{~b}$ & $\mathrm{a}$ & a & a & c & a & $c$ & c & $\mathrm{a}$ & $\mathrm{d}$ & $\mathrm{d}$ & $\mathrm{dh}$ & a & $\mathrm{e}$ & $b$ & $\mathrm{e}$ & $b$ & $\mathrm{a}$ \\
\hline$b$ & $\mathrm{~cd}$ & d & $\mathrm{b}$ & a & a & a & c & $a$ & ac & $\mathrm{c}$ & a & $\mathrm{d}$ & $\mathrm{d}$ & $\mathrm{dh}$ & a & $\mathrm{e}$ & $b$ & eg & $b$ & a \\
\hline$b$ & $\mathrm{e}$ & $\mathrm{d}$ & $\mathrm{b}$ & $\mathrm{a}$ & $\mathrm{a}$ & $\mathrm{a}$ & C & a & ce & bc & $\mathrm{a}$ & $\mathrm{bd}$ & df & $\mathrm{d}$ & $\mathrm{a}$ & $\mathrm{e}$ & b & eg & $\mathrm{b}$ & a \\
\hline $\mathrm{b}$ & $\mathrm{cd}$ & $\mathrm{d}$ & $\mathrm{b}$ & $a$ & a & a & c & a & bc & $\mathrm{c}$ & a & $\mathrm{d}$ & $\mathrm{d}$ & $\mathrm{df}$ & $a$ & $\mathrm{e}$ & $\mathrm{b}$ & eg & $\mathrm{bd}$ & $a$ \\
\hline$b$ & $c$ & $\mathrm{~d}$ & $b$ & $\mathrm{a}$ & a & - & $c$ & a & c & c & a & $\mathrm{b}$ & $\mathrm{d}$ & $\mathrm{df}$ & a & $\mathrm{e}$ & $b$ & $\mathrm{~g}$ & $\mathrm{~b}$ & $\mathrm{a}$ \\
\hline $\mathrm{b}$ & $\mathrm{cd}$ & d & $\mathrm{b}$ & $\mathrm{a}$ & $\mathrm{a}$ & $\mathrm{a}$ & ac & $\mathrm{a}$ & $\mathrm{c}$ & c & $\mathrm{a}$ & $\mathrm{d}$ & $\mathrm{df}$ & $\mathrm{g}$ & $\mathrm{a}$ & $\mathrm{e}$ & $\mathrm{b}$ & gi & $b$ & $\mathrm{c}$ \\
\hline $\mathrm{b}$ & $\mathrm{e}$ & $\mathrm{d}$ & $b$ & $\mathrm{a}$ & a & $a^{\circ}$ & C & a & be & c & a & $\mathrm{d}$ & $\mathrm{d}$ & $\mathrm{dh}$ & $\mathrm{a}$ & $\mathrm{e}$ & $b$ & eg & $b$ & $\mathrm{a}$ \\
\hline $\mathrm{b}$ & $\mathrm{d}$ & $\mathrm{d}$ & $\mathrm{d}$ & a & a & a & c & a & $\mathrm{cd}$ & c & a & $\mathrm{b}$ & $\mathrm{d}$ & $f$ & $a b$ & $\mathrm{~d}$ & b & $\mathrm{e}$ & $b$ & $c$ \\
\hline $\mathrm{b}$ & $\mathrm{e}$ & $\mathrm{d}$ & de & $\mathrm{a}$ & a & a & c & $\mathrm{a}$ & ce & $c$ & $\mathrm{a}$ & $\mathrm{b}$ & ad & $f$ & $a$ & $\mathrm{~d}$ & $\mathrm{~b}$ & $\mathrm{e}$ & $b$ & C \\
\hline$b$ & de & $\mathrm{d}$ & $\mathrm{de}$ & $\mathrm{a}$ & $\mathrm{a}$ & a & $c$ & $a$ & ce & C & $a$ & $\mathrm{bd}$ & $\mathrm{d}$ & $\mathrm{f}$ & a & $\mathrm{d}$ & b & ei & $b$ & C \\
\hline$b$ & $\mathrm{~cd}$ & $\mathrm{~d}$ & $\mathrm{~d}$ & a & $a b$ & a & $\mathrm{bc}$ & $a$ & $\mathrm{C}$ & c & $\mathrm{a}$ & $\mathrm{b}$ & $\mathrm{d}$ & $\mathrm{h}$ & $\mathrm{a}$ & $d$ & b & ef & $b$ & C \\
\hline $\mathrm{b}$ & $\mathrm{d}$ & d & $\mathrm{d}$ & a & $a$ & a & C & $a$ & $\mathrm{bd}$ & c & $a b$ & $\mathrm{~b}$ & $\mathrm{~d}$ & fh & a & $\mathrm{d}$ & $\mathrm{b}$ & eh & $\mathrm{b}$ & C \\
\hline $\mathrm{b}$ & $\mathrm{d}$ & d & $\mathrm{d}$ & a & a & a & c & a & $\mathrm{bc}$ & c & $a$ & $\mathrm{~b}$ & $\mathrm{~d}$ & $\mathrm{~h}$ & $a$ & $\mathrm{~d}$ & $\mathrm{~b}$ & $\mathrm{e}$ & $\mathrm{b}$ & C \\
\hline $\mathrm{b}$ & de & $\mathrm{d}$ & $\mathrm{d}$ & $a$ & a & a & c & a & $\mathrm{cd}$ & $c$ & a & $b$ & $\mathrm{~d}$ & $\mathrm{fg}$ & $a b$ & - & $b$ & $\mathrm{ij}$ & $\mathrm{b}$ & $\mathrm{c}$ \\
\hline c & $\mathrm{e}$ & $\mathrm{d}$ & $\mathrm{d}$ & $a$ & $\mathrm{a}$ & $b$ & c & a & c & $c$ & $\mathrm{a}$ & $b$ & $\mathrm{~d}$ & $\mathrm{~h}$ & $\mathrm{a}$ & c & $\mathrm{b}$ & $\mathrm{m}$ & $\mathrm{b}$ & $c$ \\
\hline C & $\mathrm{e}$ & $\mathrm{d}$ & $\mathrm{d}$ & a & a & $\mathrm{b}$ & c & a & $c$ & $c$ & a & $b$ & $\mathrm{~d}$ & $\mathrm{~h}$ & $\mathrm{a}$ & $c$ & $a b$ & $\mathrm{~m}$ & $\mathrm{~b}$ & ac \\
\hline b & $c$ & $\mathrm{~d}$ & $\mathrm{~b}$ & a & a & a & c & a & c & $c$ & a & $\mathrm{d}$ & $\mathrm{bd}$ & $\mathrm{d}$ & a & ce & $\mathrm{b}$ & $\mathrm{g}$ & $\mathrm{b}$ & $\mathrm{a}$ \\
\hline b & c & $\mathrm{d}$ & $\mathrm{b}$ & $\mathrm{a}$ & $\mathrm{a}$ & a & C & $\mathrm{a}$ & c & c & $\mathrm{a}$ & $\mathrm{d}$ & $\mathrm{f}$ & de & a & ce & $\mathrm{b}$ & $\mathrm{g}$ & $b$ & $\mathrm{a}$ \\
\hline $\mathrm{b}$ & d & d & $\mathrm{bc}$ & $a$ & a & $b$ & c & a & c & c & a & $b$ & $\mathrm{~d}$ & $\mathrm{~d}$ & a & $\mathrm{d}$ & $b$ & $\mathrm{e}$ & $b$ & C \\
\hline b & $c$ & $\mathrm{~d}$ & $\mathrm{~b}$ & a & a & $\mathrm{b}$ & c & a & $c$ & c & a & b & $\mathrm{bd}$ & $\mathrm{f}$ & a & $\mathrm{d}$ & $\mathrm{b}$ & e & $\mathrm{b}$ & $\mathrm{bc}$ \\
\hline $\mathrm{b}$ & $\mathrm{d}$ & $\mathrm{d}$ & $\mathrm{b}$ & $\mathrm{a}$ & $\mathrm{a}$ & b & c & $a$ & $\mathrm{~cd}$ & c & $\mathrm{a}$ & $\mathrm{b}$ & $\mathrm{bd}$ & $\mathrm{bd}$ & a & $\mathrm{d}$ & b & $\mathrm{e}$ & $b$ & C \\
\hline be & $\mathrm{e}$ & d & $\mathrm{d}$ & $a$ & $\mathrm{a}$ & b & c & $a b$ & $\mathrm{e}$ & c & a & b & $\mathrm{d}$ & $\mathrm{f}$ & a & $\mathrm{d}$ & $\mathrm{b}$ & $\mathrm{e}$ & $b c$ & C \\
\hline $\mathrm{e}$ & $\mathrm{ce}$ & $\mathrm{d}$ & $\mathrm{d}$ & a & a & $\mathrm{b}$ & $c$ & $a b$ & $\mathrm{~d}$ & $\mathrm{C}$ & a & $\mathrm{b}$ & $\mathrm{d}$ & bf & a & $\mathrm{d}$ & b & $\mathrm{e}$ & $b$ & c \\
\hline b & ae & $\mathrm{d}$ & $\mathrm{d}$ & $a$ & $\mathrm{a}$ & $b$ & c & $\mathrm{a}$ & $\mathrm{d}$ & $b c$ & a & $\mathrm{bd}$ & $\mathrm{d}$ & fh & $a$ & $\mathrm{~d}$ & b & $\mathrm{e}$ & $\mathrm{b}$ & C \\
\hline $\mathrm{b}$ & $\mathrm{c}$ & $\mathrm{d}$ & $\mathrm{d}$ & a & a & $b$ & c & $\mathrm{a}$ & $\mathrm{c}$ & $\mathrm{c}$ & a & $\mathrm{d}$ & $\mathrm{d}$ & $\mathrm{fi}$ & a & $\mathrm{d}$ & b & $\mathrm{e}$ & $b c$ & C \\
\hline be & $\mathrm{e}$ & $\mathrm{d}$ & $\mathrm{d}$ & a & $\mathrm{a}$ & $\mathrm{b}$ & c & $\mathrm{a}$ & $\mathrm{ce}$ & $c$ & a & $\mathrm{d}$ & d & $\mathrm{h}$ & a & $\mathrm{d}$ & $\mathrm{b}$ & e & $\mathrm{bc}$ & C \\
\hline $\mathrm{b}$ & c & $\mathrm{d}$ & $\mathrm{d}$ & $\mathrm{a}$ & a & $\mathrm{b}$ & c & $\mathrm{a}$ & $\mathrm{e}$ & c & a & $\mathrm{d}$ & d & fh & $\mathrm{a}$ & $\mathrm{d}$ & b & $\mathrm{e}$ & $\mathrm{b}$ & C \\
\hline be & e & d & bd & $\mathrm{a}$ & $\mathrm{a}$ & $\mathrm{b}$ & c & $a b$ & $\mathrm{e}$ & $c$ & a & $\mathrm{d}$ & d & $\mathrm{fi}$ & a & $\mathrm{d}$ & $b$ & $\mathrm{~g}$ & C & c \\
\hline $\mathrm{b}$ & e & $\mathrm{d}$ & $b$ & a & $a$ & $\mathrm{~b}$ & $\mathrm{c}$ & $\mathrm{a}$ & c & $\mathrm{c}$ & $\mathrm{a}$ & $a b$ & $\mathrm{~d}$ & $\mathrm{f}$ & $\mathrm{a}$ & $\mathrm{bd}$ & $b$ & C & a & $c$ \\
\hline$b$ & C & $\mathrm{d}$ & $\mathrm{d}$ & $a$ & a & b & c & a & $c$ & $c$ & a & $\mathrm{d}$ & $\mathrm{d}$ & fh & a & $\mathrm{d}$ & $\mathrm{b}$ & e & $\mathrm{b}$ & C \\
\hline $\mathrm{b}$ & c & $\mathrm{d}$ & $\mathrm{d}$ & $\mathrm{a}$ & a & $\mathrm{b}$ & $c$ & $a$ & ce & $c$ & a & $\mathrm{d}$ & $\mathrm{d}$ & $\mathrm{h}$ & $\mathrm{a}$ & $\mathrm{d}$ & $\mathrm{b}$ & $\mathrm{e}$ & $\mathrm{b}$ & C \\
\hline be & c & $\mathrm{d}$ & $\mathrm{d}$ & $\mathrm{a}$ & $\mathrm{a}$ & $\mathrm{b}$ & c & $\mathrm{a}$ & $\mathrm{cd}$ & c & a & $\mathrm{d}$ & $\mathrm{d}$ & $\mathrm{df}$ & a & $\mathrm{d}$ & $b$ & $\mathrm{e}$ & $\mathrm{b}$ & c \\
\hline $\mathrm{b}$ & $\mathrm{e}$ & $\mathrm{d}$ & $\mathrm{b}$ & $\mathrm{a}$ & a & $\mathrm{b}$ & c & a & $\mathrm{e}$ & C & $\mathrm{a}$ & $\mathrm{d}$ & $\mathrm{d}$ & $\mathrm{h}$ & a & $\mathrm{d}$ & $\mathrm{b}$ & eg & $\mathrm{bc}$ & C \\
\hline $\mathrm{b}$ & $\mathrm{e}$ & $\mathrm{d}$ & b & a & a & $\mathrm{b}$ & $c$ & $\mathrm{a}$ & $\mathrm{e}$ & C & a & $\mathrm{d}$ & $\mathrm{d}$ & $\mathrm{h}$ & a & $\mathrm{d}$ & $\mathrm{b}$ & $\mathrm{e}$ & c & C \\
\hline be & e & $\mathrm{d}$ & $\mathrm{b}$ & $\mathrm{a}$ & a & $\mathrm{b}$ & c & $\mathrm{b}$ & $\mathrm{e}$ & c & a & $\mathrm{d}$ & $\mathrm{d}$ & fh & $\mathrm{a}$ & $\mathrm{d}$ & $\mathrm{b}$ & $\mathrm{C}$ & c & C \\
\hline $\mathrm{e}$ & e & $\mathrm{d}$ & $b$ & a & $\mathrm{a}$ & $\mathrm{b}$ & c & $\mathrm{a}$ & $c$ & $\mathrm{C}$ & a & $\mathrm{d}$ & $\mathrm{d}$ & $\mathrm{dh}$ & a & - & $\mathrm{b}$ & ce & b & C \\
\hline e & e & $\mathrm{d}$ & $b$ & a & a & $\mathrm{b}$ & c & $\mathrm{a}$ & eg & $c$ & a & $\mathrm{d}$ & $\mathrm{d}$ & $\mathrm{gh}$ & a & de & $\mathrm{b}$ & $c$ & $b$ & C \\
\hline $\mathrm{e}$ & e & $\mathrm{d}$ & $\mathrm{d}$ & a & a & $\mathrm{b}$ & c & $\mathrm{a}$ & b & $\mathrm{cd}$ & a & de & $\mathrm{d}$ & $\mathrm{f}$ & a & $\mathrm{d}$ & b & C & $\mathrm{b}$ & C \\
\hline $\mathrm{e}$ & c & $\mathrm{d}$ & $\mathrm{d}$ & $a$ & $\mathrm{a}$ & $\mathrm{b}$ & $c$ & a & $\mathrm{e}$ & $\mathrm{cd}$ & a & $\mathrm{d}$ & $\mathrm{d}$ & $\mathrm{f}$ & a & $\mathrm{d}$ & $\mathrm{b}$ & $\mathrm{dg}$ & $\mathrm{b}$ & c \\
\hline e & c & $\mathrm{d}$ & bd & a & a & $\mathrm{b}$ & c & $\mathrm{a}$ & $\mathrm{b}$ & $\mathrm{cd}$ & a & $\mathrm{d}$ & $\mathrm{d}$ & $\mathrm{f}$ & a & $\mathrm{d}$ & $\mathrm{b}$ & $\mathrm{e}$ & $\mathrm{b}$ & c \\
\hline $\mathrm{e}$ & $\mathrm{e}$ & ad & $\mathrm{d}$ & $a$ & a & $\mathrm{b}$ & c & $a$ & $\mathrm{e}$ & C & $a$ & $\mathrm{~d}$ & $\mathrm{bd}$ & $\mathrm{f}$ & a & $\mathrm{d}$ & $\mathrm{b}$ & ce & $\mathrm{b}$ & C \\
\hline $\mathrm{e}$ & $\mathrm{e}$ & $\mathrm{ad}$ & $\mathrm{d}$ & $\mathrm{a}$ & a & $\mathrm{b}$ & c & a & $\mathrm{e}$ & c & a & $\mathrm{d}$ & $\mathrm{b}$ & $\mathrm{fg}$ & $\mathrm{a}$ & $\mathrm{d}$ & $\mathrm{b}$ & ce & $\mathrm{b}$ & C \\
\hline e & $\mathrm{e}$ & a & $\mathrm{d}$ & $a$ & a & $\mathrm{b}$ & c & a & $\mathrm{e}$ & c & a & $\mathrm{d}$ & $\mathrm{bd}$ & fg & a & $\mathrm{d}$ & $\mathrm{b}$ & $c$ & $\mathrm{~b}$ & c \\
\hline $\mathrm{e}$ & e & $\mathrm{d}$ & $\mathrm{d}$ & $\mathrm{a}$ & $\mathrm{a}$ & $\mathrm{b}$ & C & $a$ & e & C & $\mathrm{a}$ & ce & $\mathrm{d}$ & $\mathrm{f}$ & $\mathrm{a}$ & $\mathrm{d}$ & $b$ & C & $\mathrm{b}$ & c \\
\hline ac & $c$ & b & $b$ & $\mathrm{a}$ & a & a & c & a & C & $c$ & a & $\mathrm{d}$ & $\mathrm{df}$ & fh & a & $\mathrm{df}$ & b & 1 & $\mathrm{~b}$ & c \\
\hline bc & $\mathrm{cd}$ & b & b & $\mathrm{a}$ & a & a & $c$ & a & $\mathrm{c}$ & c & a & $\mathrm{d}$ & $\mathrm{d}$ & $\mathrm{dh}$ & a & d & $b$ & 1 & $\mathrm{~b}$ & $c$ \\
\hline $\mathrm{bc}$ & $\mathrm{c}$ & $\mathrm{d}$ & $b$ & $\mathrm{a}$ & a & $a$ & C & a & cf & C & a & $\mathrm{d}$ & $d$ & $\mathrm{~d}$ & $\mathrm{a}$ & $\mathrm{d}$ & $\mathrm{b}$ & 1 & $\mathrm{~b}$ & c \\
\hline $\mathrm{b}$ & $\mathrm{de}$ & $\mathrm{b}$ & b & $a$ & a & $a$ & c & a & $\mathrm{b}$ & c & $\mathrm{a}$ & $\mathrm{b}$ & $\mathrm{d}$ & $\mathrm{f}$ & a & $\mathrm{d}$ & b & $\mathrm{e}$ & $\mathrm{b}$ & C \\
\hline$c$ & $\mathrm{~cd}$ & $\mathrm{~d}$ & $\mathrm{~b}$ & $a$ & a & a & c & $\mathrm{a}$ & C & c & $\mathrm{a}$ & $\mathrm{bd}$ & $\mathrm{d}$ & $\mathrm{di}$ & $\mathrm{a}$ & $\mathrm{d}$ & $\mathrm{b}$ & 1 & $\mathrm{~b}$ & c \\
\hline $\mathrm{bc}$ & $\mathrm{c}$ & $\mathrm{d}$ & $b$ & $a$ & $\mathrm{a}$ & a & c & $a$ & c & c & $a$ & $\mathrm{bd}$ & $\mathrm{d}$ & $\mathrm{d}$ & a & $\mathrm{d}$ & $\mathrm{b}$ & $\hat{1}$ & $\mathrm{~b}$ & C \\
\hline ce & C & $\mathrm{b}$ & $\mathrm{b}$ & $a$ & $a$ & a & $c$ & $a$ & $\mathrm{e}$ & c & $a$ & $\mathrm{~d}$ & $\mathrm{~d}$ & $\mathrm{di}$ & a & $\mathrm{d}$ & $\mathrm{b}$ & $\mathrm{kl}$ & $\mathrm{b}$ & C \\
\hline$c$ & $\mathrm{~cd}$ & $\mathrm{bd}$ & $a b$ & $\mathrm{a}$ & a & $\mathrm{a}$ & c & $a$ & $\mathrm{bc}$ & $c$ & $a$ & $\mathrm{~d}$ & $\mathrm{~d}$ & fj & $a$ & $\mathrm{~d}$ & $\mathrm{~b}$ & 1 & $\mathrm{~b}$ & $\mathrm{c}$ \\
\hline $\mathrm{c}$ & $\mathrm{c}$ & $\mathrm{bd}$ & $\mathrm{b}$ & $a$ & $a$ & $\mathrm{a}$ & $\mathrm{c}$ & $a$ & $\mathrm{e}$ & $\mathrm{bc}$ & $a$ & $\mathrm{bd}$ & $\mathrm{cd}$ & $\mathrm{di}$ & $\mathrm{a}$ & $\mathrm{df}$ & $\mathrm{b}$ & 1 & $\mathrm{~b}$ & $\mathrm{~cd}$ \\
\hline$b$ & $c$ & $\mathrm{~d}$ & $d$ & $\mathrm{a}$ & a & $a$ & c & $a$ & $c$ & $c$ & $a$ & $\mathrm{~b}$ & $\mathrm{~cd}$ & gh & $\mathrm{a}$ & $\mathrm{e}$ & $b$ & $\mathrm{bc}$ & $b$ & C \\
\hline$c$ & $c f$ & $\mathrm{~d}$ & d & $\mathrm{b}$ & a & a & $\mathrm{C}$ & a & c & ac & $a$ & $\mathrm{~b}$ & $\mathrm{~d}$ & fg & $a$ & $\mathrm{e}$ & $\mathrm{b}$ & $\mathrm{b}$ & $\mathrm{b}$ & c \\
\hline
\end{tabular}

